\title{
Kortbladsbeskrivelse, Geologisk kort over Danmark, 1:50 000, Møn Dele af 1511 I, 1511 IV og 1512 II
}

\section{With a summary in English}

\author{
Stig A. Schack Pedersen ${ }^{\star 1}\left(\mathbb{0}\right.$, Peter Gravesen ${ }^{1}$ \\ ${ }^{1}$ Geological Survey of Denmark and Greenland (GEUS), Copenhagen, Denmark.
}

\section{Sammendrag}

Det geologiske kortblad Møn omfatter Møn med de tilgrænsende øer Langø, Lindholm og Nyord samt mindre dele af Sjælland og Falster. Kortet består af dele af de topografiske kortblade 1511 I og 1512 II samt 1511 IV med randområder af tilgrænsende kortblade mod vest og nord.

Møn opdeles i tre geomorfologiske områder: det stærkt kuperede Høje Møn mod øst, det småbakkede landskab omkring Stege Nor mod vest, og det flade marine forland omkring Nyord og Ulfshale. Høje Møn opbygges af opskudte skiver af skrivekridt og kvartære aflejringer, som det ses i Møns Klint. Skiverne er op til 80 m tykke, hvoraf skrivekridtet udgør ca. 50 m. Under hele Møn består prækvartæroverfladen af Maastrichtien skrivekridt i en dybde omkring kote -25 til -40 m. Mindre skiver af glacialtektonisk forstyrret skrivekridt optræder også omkring Stege Nor og langs sydkysten af det vestlige Møn ved Hvideklint.

De ældste kvartære aflejringer er moræneler fra Saale-istiden og sand og ler fra Eem-mellemistiden. Derefter følger fluviale aflejringer og nedskylslag fra Tidlig Weichsel. Disse lag efterfølges af moræneler fra Ristinge Klint Till Formationen med over- og underliggende smeltevandsaflejringer fra Mellem Weichsel dannet under Ristinge Isfremstødet for ca. 55 000-50 000 år siden. Den næste enhed er Kraneled Formationen (ny formation), som efterfølges af moræneler tilhørende Klintholm Till Formationen (justeret formation) fra Klintholm Isfremstødet for 35 000-32 000 år siden. Formationen overlejres af mere end $10 \mathrm{~m}$ tykke enheder af gråt til olivengråt issøler med dropsten, smeltevandssand og lamineret fint sand samt diamikte aflejringer i Kobbelgård Formationen (ny formation). Denne formation blev aflejret i en issø, som dækkede store dele af Østersøen i en mildningsperiode for $32000-$ 28000 år siden. Denne enhed overlejres af eller er øverst sammenflettet med sand og grus tilhørende Stubberup Have Formationen (ny formation). Moræneler tilhørende den Midtdanske Till Formation blev aflejret under $\mathrm{N} \varnothing$-Isfremstødet for 23 000-20 000 år siden. Efter at $\mathrm{N} \varnothing$-Isen var smeltet tilbage fra østersøområdet, rykkede den Ungbaltiske Is frem fra den østlige del af Østersøen, hvorunder bl.a. Møns Klint og Hvideklint blev deformeret. En tilhørende strukturel enhed, Møns Klint Glacialdynamiske Kompleks, er defineret med fire sekvenser. Hele Hjelm Bugt dannede en glacial lobe, og nord herfor dannedes et randmorænestrøg. Radialt ud fra loben dannede smeltevandet store afløbskanaler fra gletsjerporte i den Ungbaltiske Is. Aflejring af

\author{
*Correspondence: sasp@geus.dk \\ Received: 04 Feb 2019 \\ Accepted: 18 Apr 2021 \\ Published: 14 Dec 2021
}

Keywords: Geologisk kort, Kvartær geologi, glacialtektonik, skrivekridt, fjeldskred

Geological map, Quaternary stratigraphy, Cretaceous chalk, glacial tectonics, landslides

\section{Abbreviations:}

GEUS: Geologiske Undersøgelser for Danmark og Grønland

HK: Hvideklint

IRSL: infrared stimulated luminescence

MIS: Marine Isotope Stage

OSL: optisk stimuleret luminiscens

LGM: seneste glaciale maksimum

TL: thermoluminescence

GEUS Bulletin is an open access, peer-reviewed journal published by the Geological Survey of Denmark and Greenland (GEUS). This article is distributed under a CC-BY 4.0 licence, permitting free redistribution, and reproduction for any purpose, even commercial, provided proper citation of the original work. Author(s) retain copyright.

Edited by: Adam A Garde (GEUS, Denmark)

Reviewed by: Helena Alexanderson (Lund University, Sweden) \& Nikolaj Krogh Larsen (University of Copenhagen, Denmark)

Funding: See page 50

Competing interests: None declared

Additional files: See page 50 
sand og grus tilhørende Ny Borre Formationen (ny formation) skete i dette tidsrum. Under det Ungbaltiske Isfremstød blev Lolland Till Formationen aflejret som et relativt tyndt lag af moræneler.

Ved slutningen af Weichsel-istiden for ca. 17000 år siden smeltede den Ungbaltiske Is tilbage. Et residualt isdække i området nordøst for Møn sendte et genfremstød til det østlige Møn, som medførte en reorientering af skrivekridtskiverne i Møns Klint. I Sen Weichsel (17 000-11 700 år før nu) fandtes søbassiner på det sydlige Møn ved Hjelm og Tøvelde samt på Høje Møn, hvor en række ferskvandslag blev dannet, og aflejringen fortsatte et stykke ind i Holocæn.

I Holocæn blev de tidligere afløbskanaler transgrederet under den atlantiske havstigning, hvorved fjorde skar sig ind fra nord og nordvest til midt på Møn. Herefter begyndte udbygningen af marine forlande, især mod nord i området Ulvshale og Nyord. De tidligere fjorde voksede til med planter, som omdannedes til tørveaflejringer. Den sidste sedimentationsfase skete langs kysterne, hvor strandvolde blev akkumuleret, og kystklitter af flyvesand blev dannet.

\section{Introduktion}

\section{Topografi}

Det geologiske kortblad Møn i skala 1:50 000 omfatter den nordlige halvdel af det topografiske kort $1511 \mathrm{I}$ og den sydlige halvdel af 1512 II samt en mindre del af 1511 IV (Fig. 1). Kortbladet dækker øen Møn, farvandet omkring Møn med øerne Nyord, Lindholm og Langø, samt mindre dele af Sydøstsjælland og Nordøstfalster.

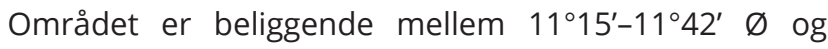
$54^{\circ} 47^{\prime}-55^{\circ} 04^{\prime} \mathrm{N}$. Alle stednavne nævnt i teksten findes på det geologiske kort eller figurerne. Kortet er indsat bagerst i kortbladsbeskrivelsen.

Kortbladsdelen på Sydøstsjælland omfatter et mindre trekantet område, som strækker sig fra Kalvehave mod nord til Sandvig Kohave med Viemose Skov og fra Kalvehave mod vest til Langebæk. Mod vest når området op til 46 m o.h. og består af en morænelerflade hældende mod kysterne, hvor holocæne havaflejringer af ler og

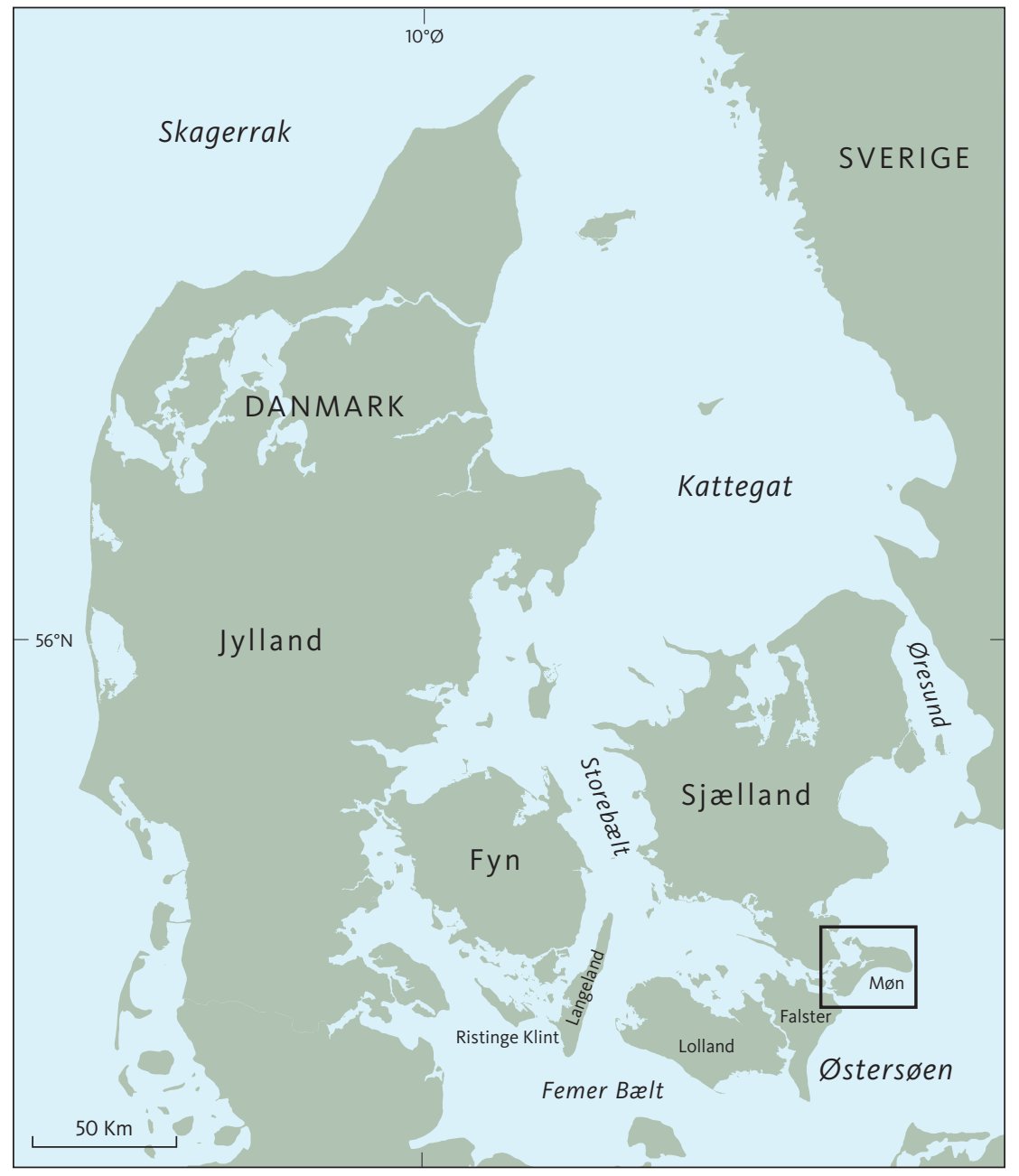

Fig. 1 Indekskort over Danmark med beliggenheden af kortbladet Møn.

Fig. 1 Index map of Denmark with the position of the map sheet Møn. 
sand findes flere steder, især ved Kindvig Hoved. Stege Bugt med øen Lindholm ligger mellem Sjælland og Møn, mens den større Langø ligger nord for Ulvsund.

På Nordøstfalster er et lille område ved Grønsund nord for Korselitse Østerskov og øst for Stubbekøbing en del af kortområdet. Det består af moræneler og inddæmmede holocæne leraflejringer i Noret. Ud mod Grønsund Færgebro og kysten sydpå mod Grønsund består vinkelforlandet også af havaflejringer, især sand, grus og rullesten af flint (Klint et al. 2017).

Ud fra højdeforholdene kan Møn inddeles i tre karakteristiske terræntyper: 1) Høje Møn, 2) det glacialmorfologiske landskab omkring Stege Nor, og 3) det flade marine forland omkring Nyord og Ulvshale. Det højeste punkt på Møn ligger i Store Klinteskov, som er det skovområde, der karakteriserer Høje Møn. Højdepunktet med topkote på 143 m o.h. ligger på Aborrebjerg, der er et markant bakkedrag oven for Aborresø. Aborrebjerg er dog ikke det eneste højdepunkt i Store Klinteskov. Adskillige toppunkter (Kongsbjerg, Lollikebakke, Lindebakker og Store Ørnebjerg) når højder over 130 m, og her findes Danmarks højest beliggende søer Aborresø, Store Geddesø og Hunesø med vandspejle tæt på 90 m o.h. Det mest dramatiske højdepunkt er dog Dronningestolen, som med sin højde på omtrent 130 m har et næsten lodret fald direkte til havet.

Den N-S-gående lavning ved Borre Sømose og Busemarke Mose, der stedvis ligger i kote 1 m o.h., adskiller Høje Møn fra det glacialmorfologiske landskab, der omkranser Stege Nor. Imellem Elmelunde og Sønderby/Borre har bakkelandet stadig en vis højde, men kommer dog aldrig over kote $50 \mathrm{~m}$. Det glacialmorfologiske landskab ligger generelt omkring kote 25 m, men hist og her optræder bakkekomplekser med højder op til kote $40 \mathrm{~m}$.

Bortset fra store områder med holocæne aflejringer: Kostervig, Nyord, Ulvshale, Maglemose, Borre Sømose, Busemarke Mose, Råbylille sø og Råby Sø, er Møns overflade domineret af glaciale Weichsel-sedimenter med stort indhold af skrivekridt. Især Høje Møn - Møns Klint og Hvideklint er eksponenter for glacialtektoniske klinter med store skrivekridtskiver mellem moræne- og smeltevandsaflejringer. Særligt på Høje Møn kan dette registreres på terrænoverfladen.

Det flade marine forland ved Ulvshale ligger tæt ved havniveau med højder på mellem 1 og 3 m o.h. De højeste områder med topkote på $3 \mathrm{~m}$ er langstrakte bakkerygge med flyvesand aflejret på strandvolde. Til disse områder hører tillige det inddæmmede område ved Klostervig samt gamle fjordområder som Borre Sømose og Maglemose. Endelig er Møns sydpynt ved Hårbølle Havn opstået som et marint vinkelforland. Store dele af kysterne består af udlignede kystklinter afbrudt af marint forland, især syd- og østkysterne, men også den østlige del af nordkysten. Mod vest fra
Ulvshale og sydpå er vestkysten guirlandeformet med Stege Nor og Fanefjord som de største indbugtninger.

Hjelm Bugt, Fakse Bugt og Stege Bugt, der omgrænser Møn, er fladvandede havområder, som skæres af få dybe sunde som Grønsund (vanddybde op til $23 \mathrm{~m}$ ) mellem Møn og Falster og Ulvsund (vanddybde op til $18 \mathrm{~m}$ ) mellem Sjælland og Møn. Der findes kun få mindre øer inden for disse havområder, hvoraf Nyord og Langø er de største.

\section{Metode}

Den systematiske geologiske kortlægning af den danske landoverflade betragtes traditionelt også som en kortlægning af de kvartærgeologiske forhold, da mere end $90 \%$ af Danmarks landoverflade består af kvartære aflejringer. Kortlægningen udføres af De Nationale Geologiske Undersøgelser for Danmark og Grønland (GEUS) og foregår ved, at geologer udstyret med karteringsspyd gennemvandrer landskabet. For hver ca. $100 \mathrm{~m}$ foretages en sondering med et karteringsspyd ned til ca. 1 m dybde, således at den kortlagte jordart repræsenterer lagene under eventuelle kulturlag og jordbundshorisonten. Prøverne, som opsamles i en lille slids i jernspyddet, bestemmes på stedet, og jordartstypen indføres på karteringskortet. Princippet i kortlægningen er dels at kortlægge jordartsgrænser i felten, dels at sikre en tilstrækkelig dækning af sonderinger inden for hver kortlagt jordartspolygon. Ofte foretages sonderingerne med tættere afstand, især hvor de geologiske grænser skal fastlægges (Gravesen et al. 2006; Jakobsen et al. 2015). Informationer fra vejskæringer, råstofgrave, andre udgravninger og kystprofiler inddrages også i kortlægningen.

I felten skelnes mellem ca. 40 forskellige jordartstyper. Disse har hver et symbol, som indtegnes på feltkort i skala 1:25 000 (Jakobsen et al. 2015; se Appendiks i Pedersen et al. 2015). Disse foreløbige jordartskort danner grundlaget for det publicerede geologiske kort. De digitaliserede foreløbige jordartskort findes i GEUS' jordartsdatabase og kan hentes på GEUS' hjemmeside (www.geus.dk).

Grundlaget for etablering af litostratigrafiske enheder i kvartære aflejringer er beskrevet i Pedersen et al. (2015). Desuden er der ved de kvartære enheder angivet, hvilket 'Marine Isotope Stage' (MIS) aflejringerne relateres til (Cohen \& Gibbard 2012). Alle aldersangivelser i denne kortbladsbeskrivelse følger Houmark-Nielsen et al. (2017).

Dataindsamlingen fra den systematiske geologiske overfladekartering opbevares i GEUS' arkiver. Langt den overvejende del af landarealet vist på kortbladet er dækket af moræneler, i alt 70 \%, som på selve Møn udgør $218 \mathrm{~km}^{2}$ foruden mindre arealer på Sydsjælland og Østfalster. De sandede glaciale aflejringer domineres af smeltevandssand og 
-grus, som træder frem i overfladen på $11 \%$ af landarealet. De resterende dele dækkes af holocæne ferskvandsaflejringer (7\%), holocæne marine aflejringer (10\%) samt skrivekridt (1\%), især på Høje Møn. Byer og befæstede anlæg (som ikke er karteret) samt ferskvandssøer udgør $1 \%$.

Siden ca. 1985 er der udført en hel del videnskabelige undersøgelser af klinterne på Syd-, Øst- og Nordmøn, herunder flere specialestudier. Desuden er der foretaget undersøgelser af råstof- og grundvandsforekomster, som er offentliggjort i rapporter. Resultater fra alle disse undersøgelser er i vid udstrækning inkluderet i denne kortbladsbeskrivelse.

\section{Kortlægningens historie}

De første geologiske observationer på Møn blev offentliggjort af Pontoppidan (1768), som med et træsnit demonstrerede den geologiske opbygning af den sydligste del af Møns Klint fra Vidskud over Græderen og Sommerspiret til Dronningestolen (se afsnit om Møns Klint).

Puggaard (1851, 1852) foretog en omhyggelig opmåling af hele Møns Klint og beskrev herudfra den geologiske opbygning af Møn. Selv om Puggaard ensidigt støttede en istektonisk dannelsesmekanisme for Møns Klint, blev det først med Johnstrups (1874) afhandling almindeligt accepteret, at flageopskydningen hidrørte fra et ispres forårsaget af en baltisk isstrøm, der ved sin $\emptyset$-V-rettede strøm gennem Østersøen både påvirkede Rügen og Møn, hvorved skrivekridtflagerne med deres morænedække blev skubbet op.

En kortlægning af Møn blev allerede forestået af K.A. Grønwall i 1906. Hintze (1937) udfærdigede et kort over Høje Møn, som fastholdt en blok-tektonisk opfattelse af deformationerne i Møns Klint. Samtlige nyere geologiske arbejder understøtter en glacialtektonisk årsag til deformationerne (Konradi 1973; Berthelsen et al. 1977; Pedersen 1988, 2000, 2011; Houmark-Nielsen 1994). På sit kort har Hintze (1937) tolket samtlige afløbsløse huller som jordfaldshuller, altså huller opstået som en slags karstfænomener, men langt de fleste er dødishuller, spor af begravede islegemer efterladt i landskabet, da isdækket fra den Ungbaltiske Is smeltede bort.

Milthers (1948) sammenstillede et kvartærgeologisk kort over hele Danmark i målestok 1:320 000 og inddrog også Møn. På Møn er der dog kun differentieret mellem morænelandskab, inddæmmede havaflejringer og strandvoldskomplekser.

V. Haarsted præsenterede ved et møde i Dansk Geologisk Forening i januar 1955 et geomorfologisk terrænkort og et jordbundskort i målestok 1:20 000 over Møn. En sammenfatning af de geologiske forhold findes i et oversigtskort trykt i referatet af foredraget (Haarsted 1956), hvor den glacialgeologiske dannelse blev understreget af bakkestrøg vist og tolket som ispreslinjer. Desuden er dalsænkninger og åsdannelser markeret.

I en kompilation af jordartskort over Danmark (Pedersen 1989) i målestok 1:200 000 blev der også inddraget oplysninger fra boringer og flyfotos. Herved blev den østligste del af Høje Møn udlagt som et område med skrivekridt, og et mindre antal skrivekridtflager blev angivet på det østligste Møn.

Den kortlægning, som er grundlaget for det nærværende kortblad over Møn, blev udført i flere perioder af forskellige geologer. V. Haarsted, der var rektor på Holte Gymnasium, afsluttede sin kortlægningsindsats i 1959. V. Münther og A.V. Nielsen kortlagde mindre arealer på Møn i årene 1966-1972. P. Gravesen og S.A.S. Pedersen afsluttede kortlægningen i årene 2004-2006, men havde forinden udarbejdet et foreløbigt kort over det østlige Møn (Pedersen \& Gravesen 2005).

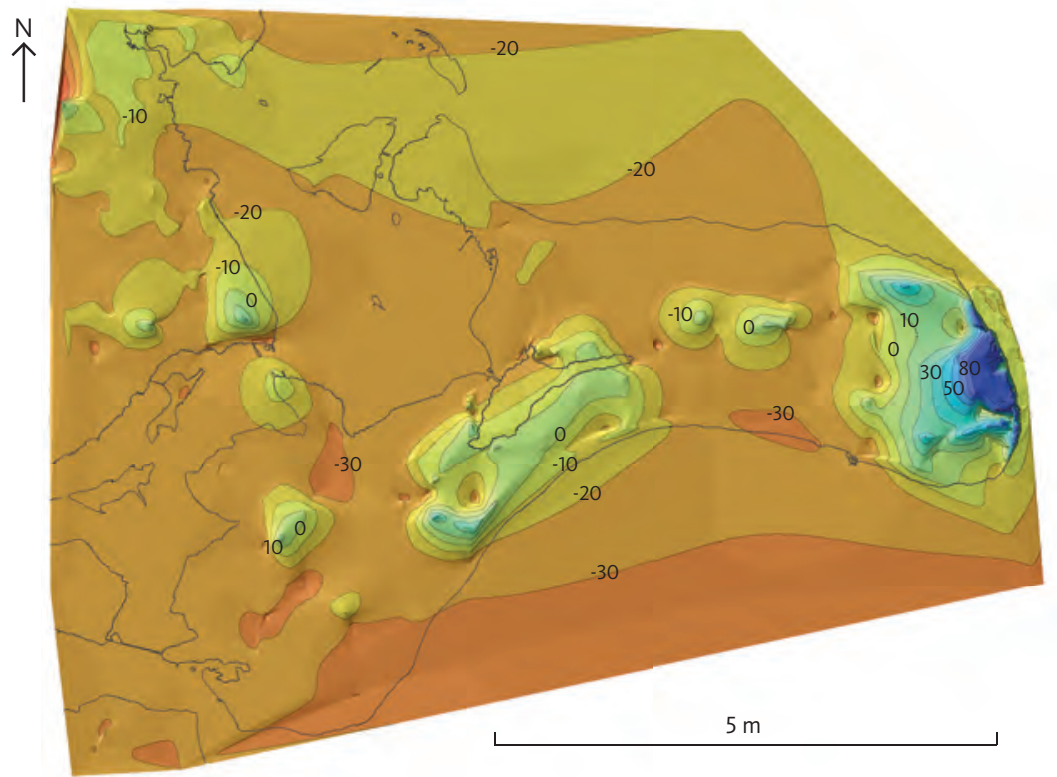

Fig. 2 Topppen af skrivekridtet under de kvartære lag, herunder dislocerede skrivekridtflager. Højdekurver vist med 10 $m$ intervaller over og under havniveau.

Fig. 2 The top of chalk below the Quaternary deposits, including chalk sheets dislocated by g/acial tectonics. Contour lines with $10 \mathrm{~m}$ intervals shown above and below sea level. 


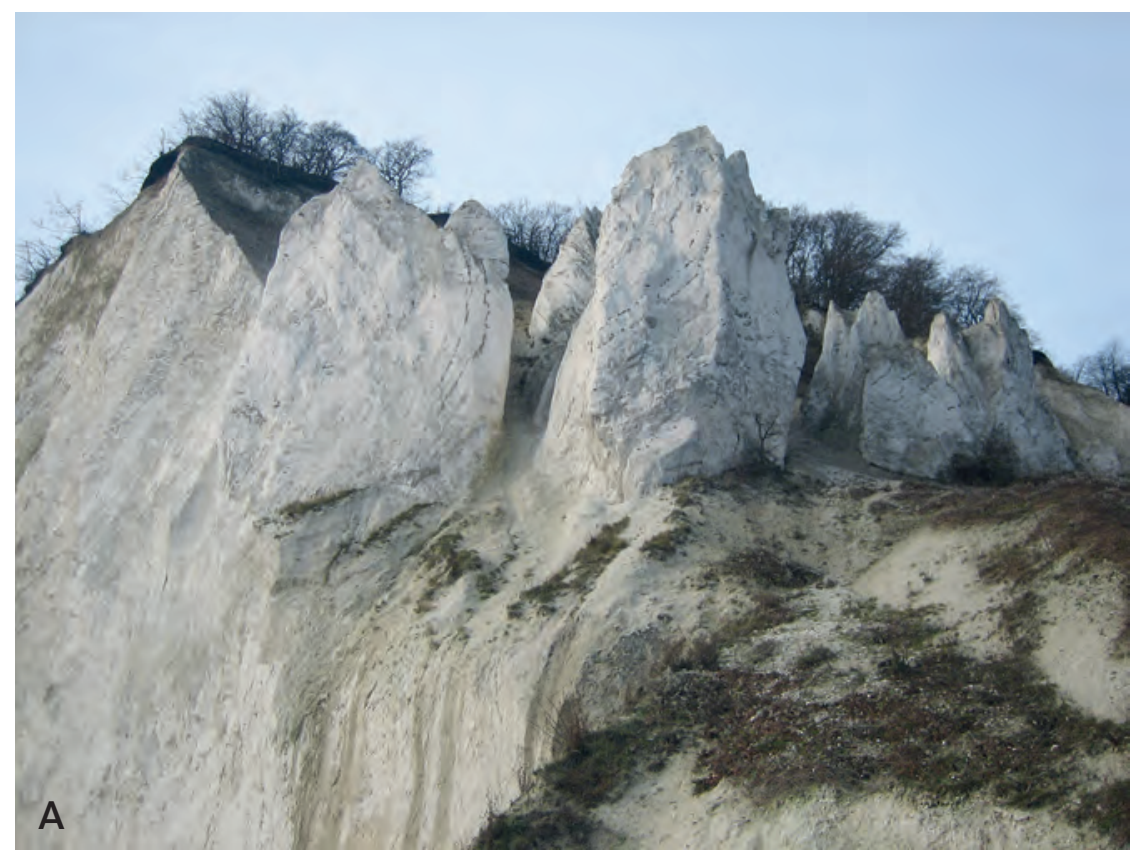

Fig. 3 Skrivekridt med sorte flintlag. A: Stærkt foldede flintlag i St. Stejlbjerg klinten, sydlige Møns Klint. Klinten er her knap 100 m høj. B: Nærbillede af sorte flintlag i skrivekridt. Den ringformede flintkonkretion nederst til venstre tolkes som udfældet omkring en Paramoudra gravegang i kridthavets bund.

Fig. 3 Pale grey chalk with black flint layers. A: Folded flint layers in the chalk cliff of St. Stejlbjerg, southern Møns Klint. The chalk cliff is here almost $100 \mathrm{~m}$ high. B: Close-up of black flint layers in chalk. The large, circular flint concretion in the lower left of the photo is interpreted as formed around a Paramoudra burrow in the Cretaceous sea floor.

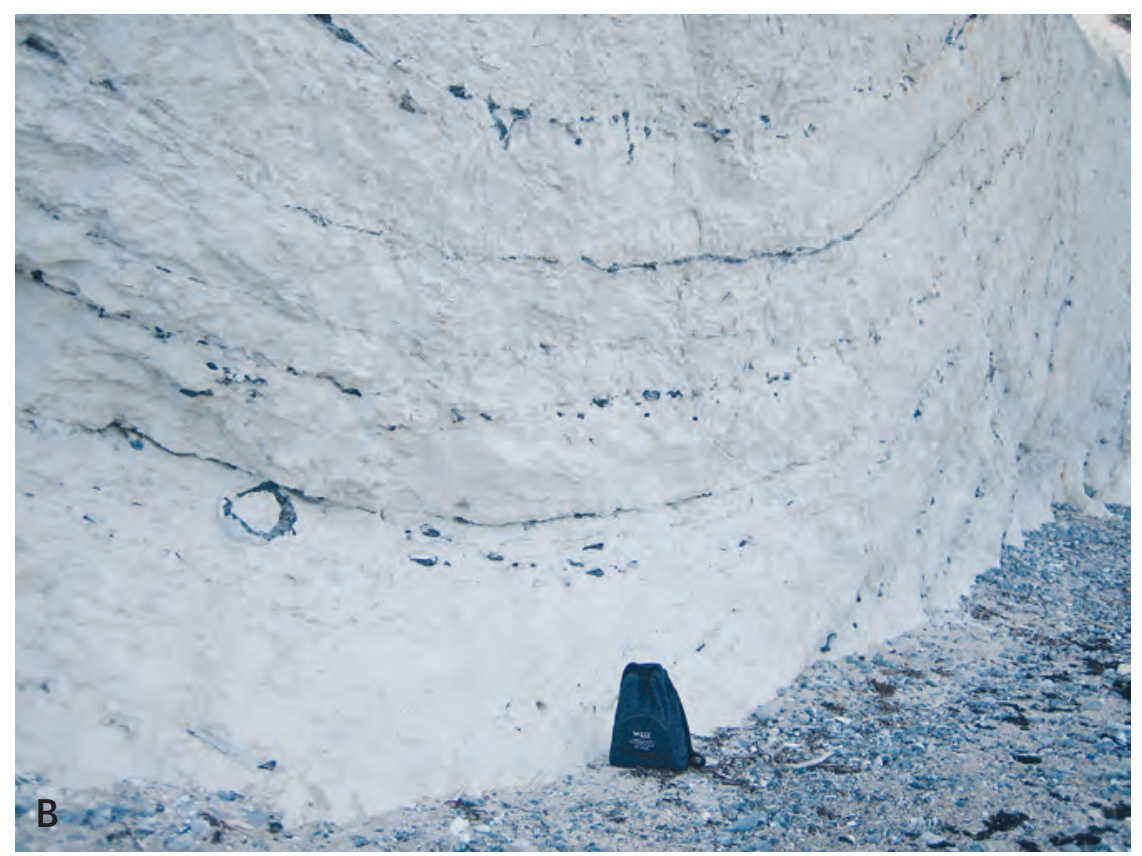

\section{Prækvartære aflejringer}

Under de pleistocæne aflejringer på Møn findes skrivekridt fra Sen Kridt (for 99,6-66,0 mio. år siden). Møn er beliggende på den sydlige del af RingkøbingFyn Højderyggen (Sorgenfrei \& Buch 1964; Sorgenfrei 1966: Håkansson \& Pedersen 1992; Surlyk et al. 2013). Denne beliggenhed gør, at der blev aflejret ca. $500 \mathrm{~m}$ tykke kalklag omkring og under Møn, mens der nordfor i Det Danske Bassin er op til 2000 m tykke kalkaflejringer (Surlyk et al. 2013). Størstedelen af disse kalkaflejringer er skrivekridt. Syd for højderyggen er der også fundet forholdsvis tynde (<500 m) lag af skrivekridt i det Tyske Bassin (Surlyk et al. 2013).

Der er ingen dybe undergrundsboringer på Møn. Den nærmeste dybe boring findes på Falster, hvor en 2,5km dyb boring, Ørslev-1, blev gennemført ved Ørslev af olieselskabet Gulf i 1967-1968 (Nielsen \& Japsen 1991; GEUS 1997). I den dybeste del af boringen blev der truffet lag fra Karbon, og ud fra seismiske data må det formodes, at grundfjeldet ligger i en dybde på mindre end $3 \mathrm{~km}$ under terrænoverfladen. Lag af stensalt, som på Lolland er trængt op i puder og mindre diapirer, findes i en dybde af 1,5 km. I Ørslev-1-boringen findes bunden af skrivekridtet i en dybde af $450 \mathrm{~m}$.

\section{Skrivekridt fra Sen Kridt}

Skrivekridtet er tilgængeligt sammen med og indlejret i de kvartære aflejringer mange steder langs Møns kyst i 


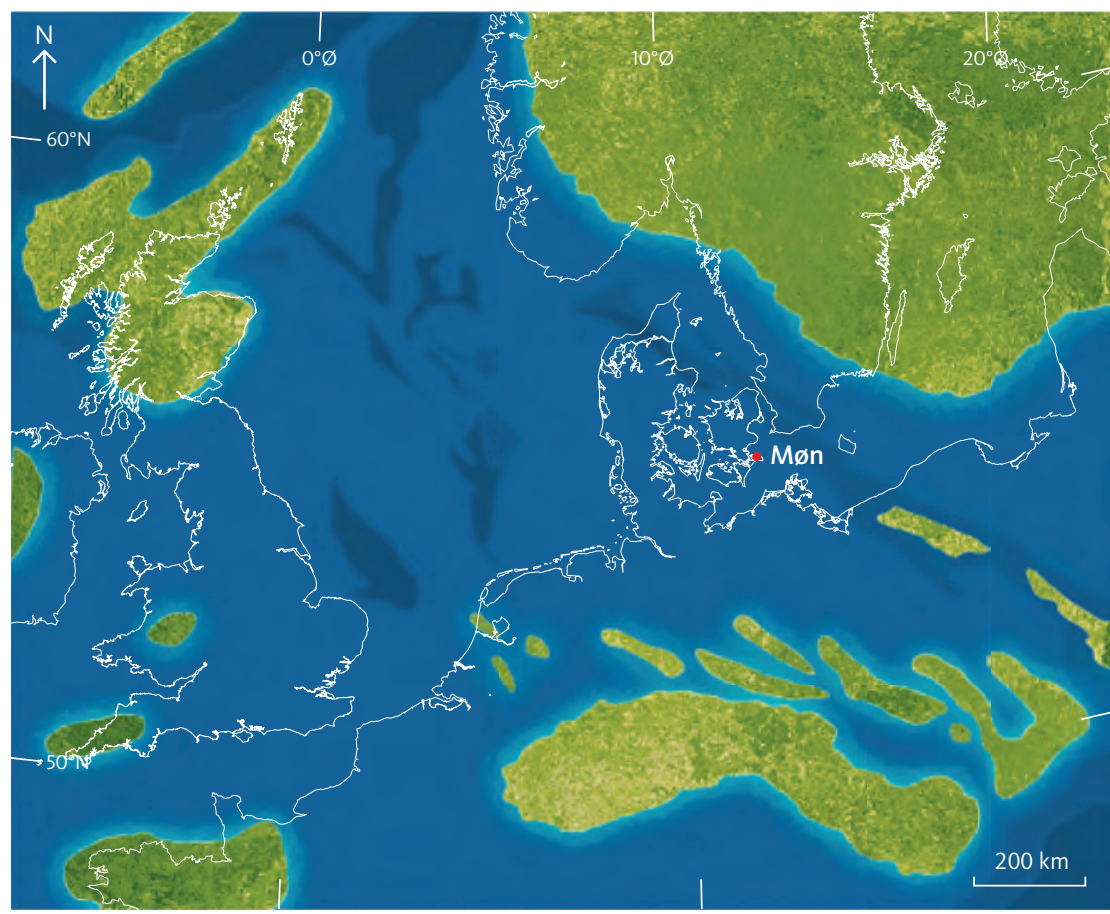

Fig. 4 Palæogeografisk kort over Sen Kridt i Nordeuropa med fordeling af land (grønt) og hav (blåt). Fra Gravesen et al. (2017) efter Damholt \& Surlyk (2012).

Fig. 4 Palaeogeographic map of the Late Cretaceous sea in Northern Europe. Green: land areas. Blue: sea. From Gravesen et al. (2017) after Damholt \& Surlyk (2012).

de glacialtektonisk påvirkede kystprofiler, men træffes kun faststående i boringer. Boredata viser, at prækvartæroverfladen på store dele af Møn ligger mellem 25-40 m u.h. og udgør en relativt plan flade, som kun stedvis når ned til større dybder (se profiler på kortbladet samt i Houmark-Nielsen 2003). Beliggenheden af overfladen under de opskudte skiver på Høje Møn er dårligt kendt, men er muligvis dybere end på det øvrige Møn. I området nord for Hvideklint når overfladen helt op omkring kote $0 \mathrm{~m}$, men det skyldes sandsynligvis en del opskudte flager. Fra området omkring Elmelunde til Borre ligger prækvartæroverfladen også i kote 0 m, formodentlig af samme grund (Fig. 2).

Skrivekridtet er en hvid, gråhvid eller gullig, blød, slammet kalkbjergart (Fig. 3), som næsten udelukkende

\begin{tabular}{|c|c|c|c|c|}
\hline \multicolumn{3}{|c|}{ Alder } & \multicolumn{2}{|c|}{ Litostratigrafisk enhed } \\
\hline \multicolumn{2}{|c|}{ Danien } & $\mathrm{N}$ & & Cerithium Kalk Led / Fiskeler Led \\
\hline \multirow{4}{*}{$\begin{array}{l}\frac{5}{0} \\
\frac{\underline{\alpha}}{w} \\
\frac{\alpha}{\alpha} \\
\vec{Q}\end{array}$} & \multirow{2}{*}{ 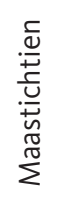 } & $\varnothing$ & \multirow{2}{*}{ 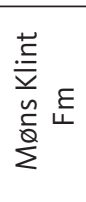 } & $\begin{array}{l}\text { Højerup Led } \\
\text { Sigerslev Led } \\
\text { Rørdal Led }\end{array}$ \\
\hline & & $\mathrm{N}$ & & Hvidskud Led \\
\hline & \multirow{2}{*}{ 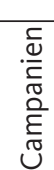 } & \multirow{2}{*}{$\varnothing$} & \multirow{2}{*}{ 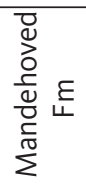 } & Boesdal Led \\
\hline & & & & Flagbanke Led \\
\hline
\end{tabular}

Fig. 5 Stratigrafisk inddeling af øverste Kridt og nederste Danien i Østdanmark (efter Surlyk et al. 2006, 2013).

Fig. 5 Stratigraphic division of the uppermost Cretaceous and lowermost Danian in eastern Denmark (after Surlyk et al. 2006, 2013). består af kokkolitter, rester af $\mu \mathrm{m}$-store plader fra marine alger (kokkosfærer). Større dyrefossiler af snegle, muslinger, brachiopoder, søpindsvin og kiselsvampe træffes også. Skrivekridtet er ofte gennemgravet af dyr, som har levet på havbunden eller inde i sedimentet (Surlyk 1971, 2017; Surlyk \& Håkansson 1999).

Skrivekridtet indeholder sort flint i mere eller mindre sammenhængende lag (Fig. 3; Madsen \& Stemmerik 2010). Flintlagene viser stedvis, at skrivekridtet er aflejret på flade banker (Surlyk et al. 2006) i et stort hav, som dækkede det meste af Nordeuropa, og hvor der næsten ikke forekom klastisk sedimentation (Fig. 4). Dog træffes tynde, cyklisk aflejrede mergellag i dele af Maastrichtien.

Skrivekridtaflejringerne fra Sen Kridt i Østdanmark inddeles i to formationer: Mandehoved Formationen med to led (det meste af Campanien) og Møns Klint Formationen med fem led (Sen Campanien - Maastrichtien, Surlyk et al. 2013). Inddelingen er baseret på undersøgelser ved Stevns Klint (Surlyk et al. 2006) og analyser fra en ca. $440 \mathrm{~m}$ dyb boring på Stevns (Stevns 1, Fig. 5; Surlyk et al. 2013). Skrivekridtaflejringerne på Møn er indpasset i denne litostratigrafi med Møns Klint Formationen, som har fået navn efter klinten. Typeprofilet består af flere af de fem led. Skrivekridtets alder er bestemt ved makro- og mikrofossiler fra klinterne på Høje Møn og Hvideklint. Analyserne giver aldre fra Nedre og Øvre Maastrichtien (Surlyk 1984; Surlyk \& Håkansson 1999; Thomsen 1995; Jelby et al. 2014). 


\section{Glaciale og interglaciale aflejringer}

\section{Data og tolkning}

På prækvartæroverfladen ligger en op til 50-100 m tyk lagserie af glaciale sedimenter, der fortrinsvis er aflejret i den sidste del af Weichsel-istiden (ca. 75000 til 11700 år før nu), men med få spor af ældre lag fra Saale-istiden (390 000 til 130000 år før nu) og Eem-mellemistiden (130 000-115 000 år før nu). De glaciale sedimenter er på det meste af Møn glacialtektonisk deformeret, foldet og forkastet, og ligeledes er store skiver af skrivekridt flyttet op fra den prækvartære overflade under Møn eller fra havområdet omkring Møn (f.eks. Berthelsen 1979; Pedersen 2000). Disse skrivekridtlag kan således betragtes som en del af de kvartære aflejringer. Desuden indgår mindre slirer af skrivekridt i de klastiske aflejringer.

Under karteringen skelnes mellem følgende glaciale jordarter: moræneler (ML), morænesand (MS) og morænegrus (MG). Hertil kommer de glaciofluviale og glaciolacustrine jordarter smeltevandsgrus (DG),

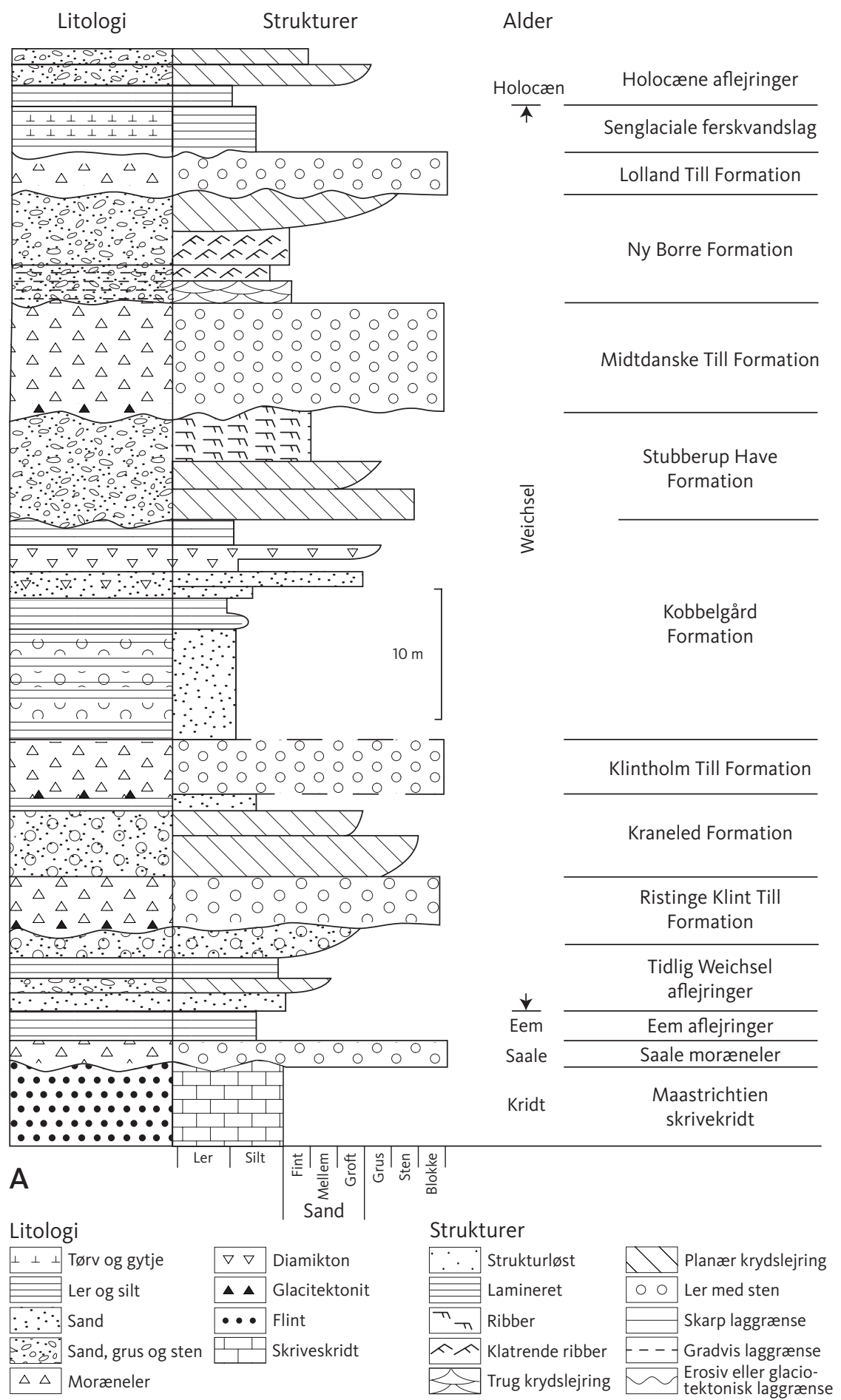

Fig. 6 A: Skematisk stratigrafisk log af kvartære interglaciale, glaciale og holocæne enheder repræsenteret på Møn-kortbladet. B: Beliggenheden af geografiske lokaliteter med reference til geologiske typelokaliteter.

Fig. 6 A: Schematic stratigraphic log of the Quaternary interglacial, glacial and Holocene deposits occurring in the Møn map sheet area. B: Locations of geographic names with reference to geological type localities. 


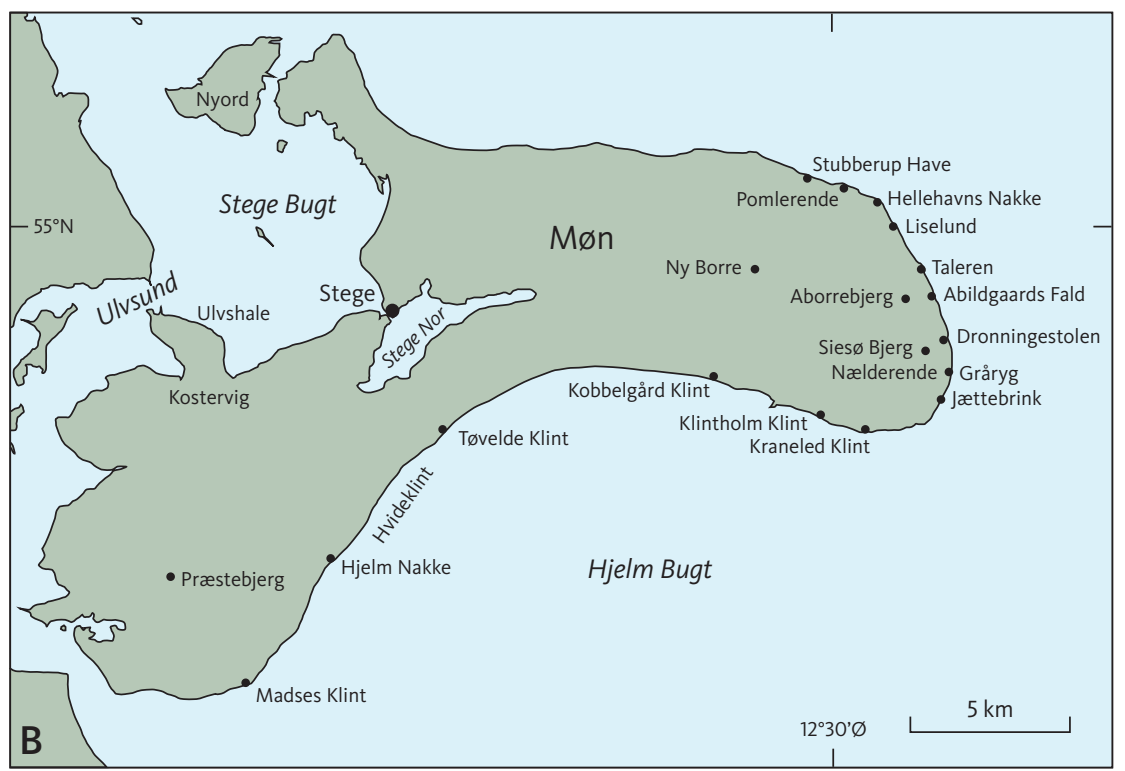

Fig. 6 (fortsættes) A: Skematisk stratigrafisk log af kvartære interglaciale, glaciale og holocæne enheder repræsenteret på Møn-kortbladet. B: Beliggenheden af geografiske lokaliteter med reference til geologiske typelokaliteter.

Fig. 6 (continued) A: Schematic stratigraphic log of the Quaternary interglacial, glacial and Holocene deposits occurring in the Møn map sheet area. B: Locations of geographic names with reference to geological type localities.

smeltevandssand (DS), smeltevandssilt (DI) og smeltevandsler (DL), og senglaciale jordarter: ferskvandsgrus (FG), ferskvandssand (FS), ferskvandsler (FL) samt skrivekridt (SK). En samlet oversigt over jordarter og symboler kan ses i Pedersen et al. (2015), appendiks 2.

Den kvartærgeologiske stratigrafi er baseret på litteratur, data og undersøgelser fra kystprofiler langs Møns syd-, øst- og nordkyster og fra få profiler i grusgrave samt på karteringen (Fig. 6A). Desuden udgør tværprofiler vist på det geologiske kort et væsentligt bidrag til forståelsen af den glaciale stratigrafi. En korrelation af formationerne med tværprofilerne er optegnet på Fig. 25. Ved udarbejdelsen af profilerne er anvendt boredata fra GEUS Borearkiv og Jupiter database (Gravesen \& Fredericia 1984). Et oversigtskort over vigtige geologiske lokaliteter på Møn kan ses på Fig. 6B.

Ældre kvartære aflejringer: Saale, Eem, Tidlig Weichsel og Tidlig Mellem Weichsel (MIS 6, 5e, $5 a-5 d, 4)$

Spredte forekomster af aflejringer fra Saale og Eem, Marine Isotope Stage (MIS) 6 og yngre, er truffet i klinterne (Fig. 6A). De indgår i de stærkt deformerede glacialtektoniske enheder som fragmenter og flager. Selv om de således ikke findes faststående, er det sandsynligt, at de har været udbredt på dele af Møn.

\section{Saale (MIS 6)}

Lag af moræneler under Eem-lagene ved Kraneled, Hellehavn Nakke og Stubberup Have (de to sidstnævnte lokaliteter med hver to lag) betragtes som værende fra Saale (Fig. 8; Hyde 1986). En del andre lokaliteter indeholder formodentlig også Saale-moræneler, selv om den omfattende glacialtektoniske påvirkning kan gøre tolkningen usikker (Puggaard 1851; Hintze 1937; Hyde 1986;
Houmark-Nielsen 1994). Lagene af moræneler er mindre end $3 \mathrm{~m}$ tykke (Fig. 7) og er antagelig fra Sen Saale (Warthe). Den glacialtektoniske påvirkning og deformation af både Saale- og Eem-lagene skete i Mellem eller Sen Weichsel (Berthelsen 1973; Aber 1979; Pedersen \& Gravesen 2009; Houmark-Nielsen 2010).

\section{Eem (MIS 5e)}

Danmark var i Eem-mellemistiden omgivet af hav, og det antages, at Eem-havet nåede ud over dele af Møn (Seidenkrantz et al. 2000), selv om en præcis udbredelse er vanskelig at fastlægge på grund af de senere

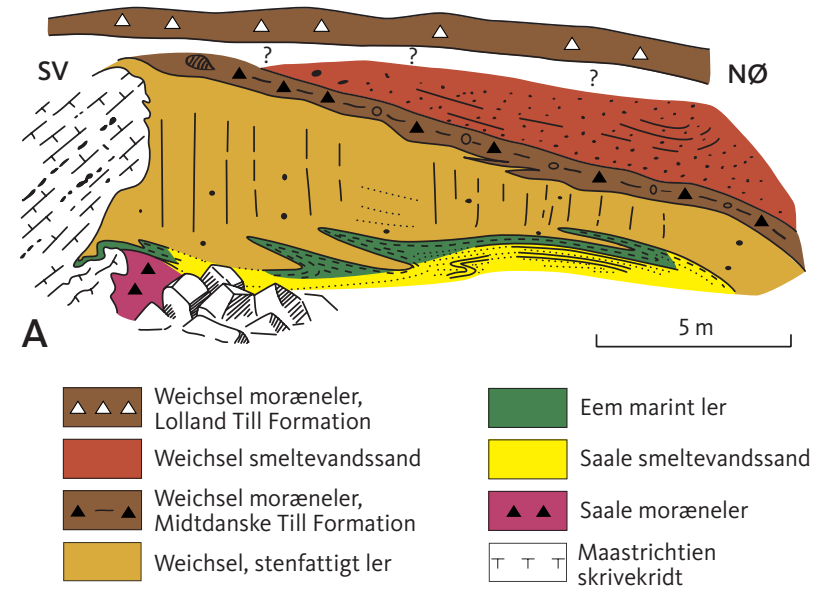

Fig. 7 Eem-aflejringer ved Hjelm Nakke. A: Feltskitse af Saale-, Eem- og Weichsel-lagene ved Hjelm Bugt fra Berthelsen et al. (1977). B: Smeltevandsler og -sand (af Saale-alder?) overlejret af marint Eem-ler. Foto: Tove Stockmarr (1996).

Fig.7. Eemian deposits at Hjelm Nakke. A: Field sketch of the Saalian, Eemian and Weichselian deposits after Berthelsen et al. (1977). B: Clay and glaciofluvial sand (Saalian?) overlain by marine Eemian clay. Photo: Tove Stockmarr (1996). 


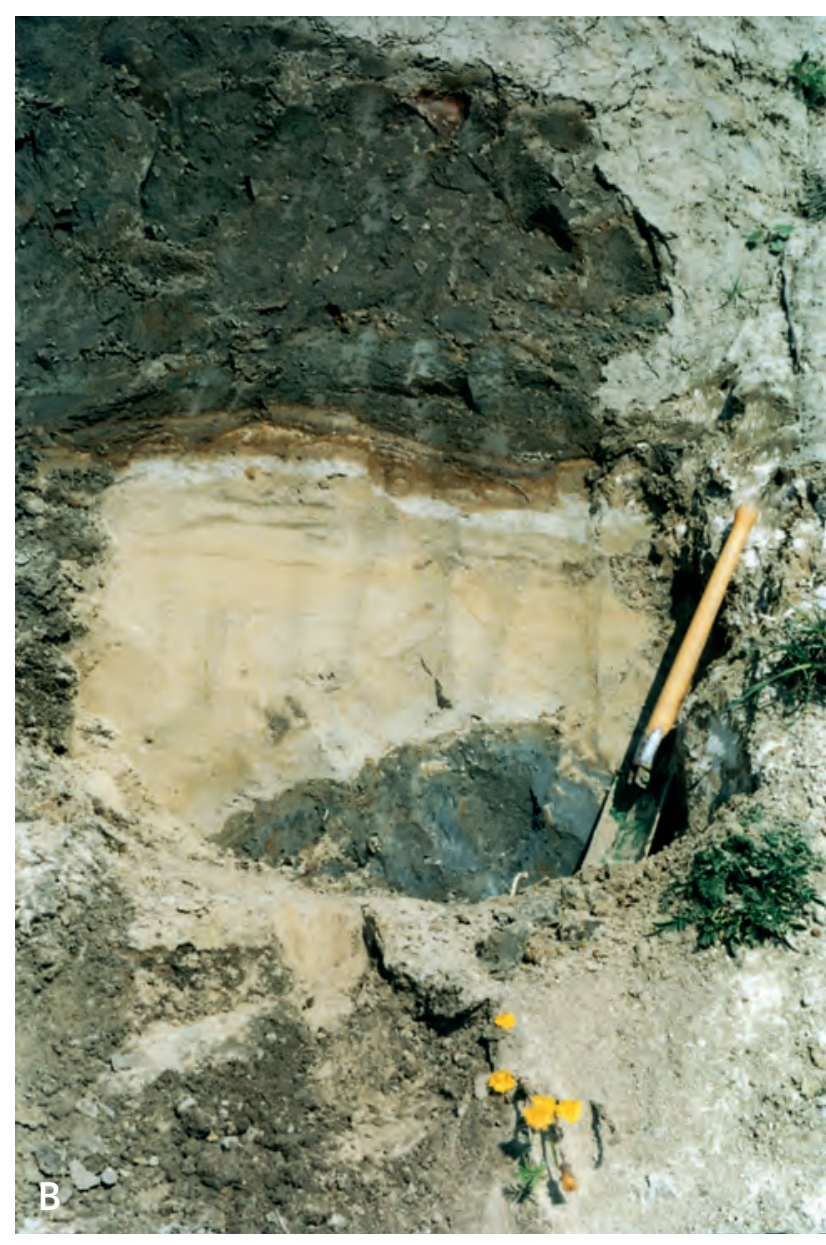

Fig. 7 (fortsættes) Eem-aflejringer ved Hjelm Nakke. A: Feltskitse af Saale-, Eem- og Weichsel-lagene ved Hjelm Bugt fra Berthelsen et al. (1977). B: Smeltevandsler og -sand (af Saale-alder?) overlejret af marint Eem-ler. Foto: Tove Stockmarr (1996).

Fig.7. (continued) Eemian deposits at Hjelm Nakke. A: Field sketch of the Saalian, Eemian and Weichselian deposits after Berthelsen et al. (1977). B: Clay and glaciofluvial sand (Saalian?) overlain by marine Eemian clay. Photo: Tove Stockmarr (1996).

glaciotektoniske påvirkninger af aflejringerne. Eemhavet er påvist fra Nordsøen gennem de danske farvande til langt ind i Østersøen mod øst, med formodet passage i Karelen i Finland og videre til Hvidehavet mod nordøst i Tidlig Eem (Knudsen et al. 2011). Selve den tidlige Eem-transgression i Østersøen ser ud til at være sket fra øst, med de ældste marine aflejringer i den Finske Bugt og yngre aflejringer i Østdanmark, Holland og Tyskland (Kristensen et al. 2000).

Den dominerende aflejring på Møn er marint, grønligt til grønsort ler (Cyprina ler), som skønsmæssigt er op til $2 \mathrm{~m}$ tykt (Fig. 7), men de fleste steder kun omkring $0,5 \mathrm{~m}$. De glacialtektoniske påvirkninger gør imidlertid denne vurdering usikker.

Marine fossiler er fundet i sand- og lerlag på nordkysten ved Øksnehøj/Orebjerg, ved Pomlerende og Stubberup Have og flere steder på Møns Klint, især i faldene, men også på ryggenes sider, f.eks. ved Hundevangsfald, Hvidskudsnakke, Lille Stejleberg, Store Stejlebjerg, Grårygfald, Fruerstuefald, Nælderende, Sandfaldet, Skrædderrenden, Maglevandsklinten/faldet, Dronningestolen, Vitmunds Nakke, Søndre Hylledalsklint, Taleren og Jydeleje Fald (Puggaard 1851; Madsen et al. 1908; Ødum 1933; Hintze 1937; Hansen \& Nielsen 1960; Hyde 1986). Desuden findes Eem-aflejringer i Kraneled Klint øst for Klintholm på Møns sydkyst (Houmark-Nielsen 1994) og på to lokaliteter i klinten mellem Hjem Nakke og Hvideklint (Fig. 7; Berthelsen et al. 1977; Stockmarr 1996). Der er desuden under de marine lag i bl.a. Store Stejlebjerg fundet gytje og sand med ferskvandsmollusker og plantefossiler fra en mellemistid (N. Hartz i Hintze 1937). Denne Eem-lagfølge fra ferskvands- til marine lag kan genfindes på andre lokaliteter i Østersøen (Kristensen et al. 2000; Knudsen et al. 2011).

Makrofossiler er både fundet i fint sand og fedt ler. Marine mollusker bærer ofte præg af påvirkning fra de glacialtektoniske episoder, men ligger øjensynligt in situ i leraflejringerne. Antallet af arter (Ødum 1933; Hintze 1937) er beskedent $i$ forhold til den omfattende liste over marine Eem-fossiler i Madsen et al. (1908).

De fossilholdige lags litologi, fossiler og alder har været diskuteret, men undersøgelser af foraminiferer har demonstreret en marin Eem-fauna ved Hjem Bugt, Kraneled og Pomlerende (V. Madsen i Hintze 1937; Berthelsen et al. 1977; J. Frederiksen i Hyde 1986; P. Kristensen i Houmark-Nielsen 1994), hvilket således underbygger tilstedeværelsen af makrofossiler fra et Eem-hav. Stedvis optræder også ler og sand mellem to lag af moræneler, hvor alle lag indeholder foraminiferer fra Eem, hvilket viser, at disse lag er omlejret (Konradi 1973).

Foraminifererne i Eem-aflejringerne har vist sig at tilhøre en boreo-lusitansk, kystnær fladvandsfauna (Berthelsen et al. 1977), som kan sammenlignes med faunaer fra andre lokaliteter i den vestlige del af Østersøen og i Nordsøen (Konradi 1976; Knudsen 1991), som har levet i havvand med lidt højere temperaturer og saltholdighed end i dag (Houmark-Nielsen 1994).

Dateringer af Eem-aflejringer fra Klintholm-Kraneled ved hjælp af optisk stimuleret luminiscens (OSL) og termoluminiscens (TL) har givet aldre, der er væsentligt yngre end forventet for Eem (yngre end 115000 år før nu). En nærmere diskussion af eventuelle årsager kan ses i Houmark-Nielsen (1994, 2008, 2010). Aminosyredateringer på udvalgte mollusker (Arctica islandica, Turritella communis og Nassa reticulata fra Klintholm, Arctica islandica og Turritella communis fra Stubberup Have og Turritella communis fra Hjelm Nakke (Petersen 1984; Miller \& Mangerud 1985; Houmark-Nielsen 1994, 2008)) understøtter, at aflejringerne fra disse klintprofiler er af Eem-alder. 

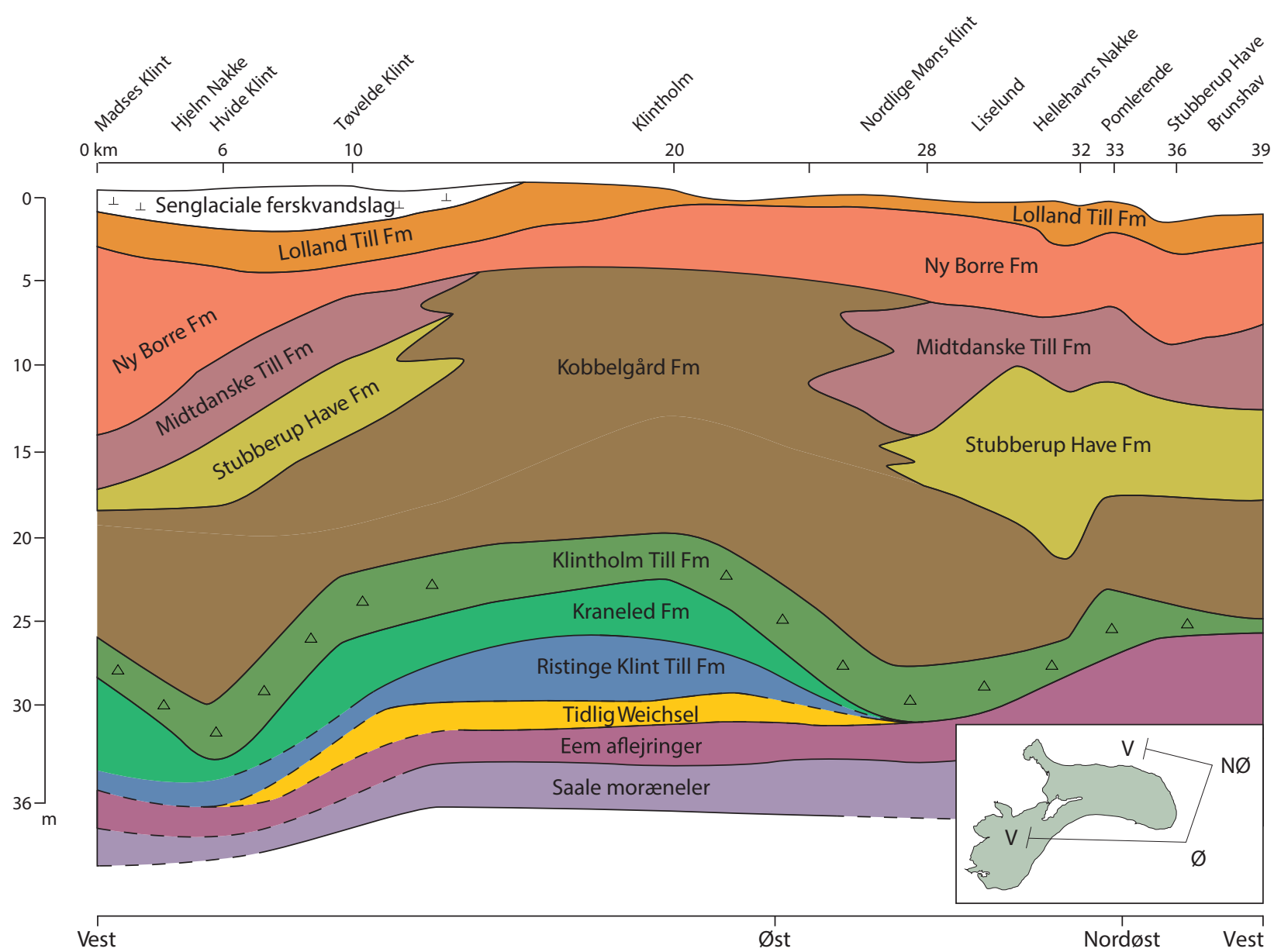

Fig. 8 Sammensat længdeprofil med tykkelser og horisontal udbredelse af de litostratigrafiske enheder på Møns syd-, øst- og nordkystklinter baseret på udvalgte vertikale logs. Indekskortet viser, hvor profilet ændrer retning. Bemærk forskellen på vertikal og horisontal skala. Baseret på Houmark-Nielsen (2010) og Gravesen et al. (2017).

Fig.8. Composite section showing the thicknesses and horizontal distribution of the lithostratigraphical units along the south, east and north coast cliffs of Møn based on selected vertical logs. The index map shows where the section changes orientation. Note different horizontal and vertical scales. Based on Houmark-Nielsen (2010) and Gravesen et al. (2017).

\section{Tidlig Weichsel og tidlig Mellem Weichsel (MIS 5a-5d, MiS 4)}

I Tidlig og tidlig Mellem Weichsel var Møn formodentlig isfrit og forholdene domineret af jordflydning og transport og aflejring i floder, dog med begrænset udbredelse. Omlejrede Eem-makrofossiler findes i disse lag (Houmark-Nielsen 1994), der vurderes til at være mellem 2 og 20 m tykke.

\section{Mellem og Sen Weichsel (MIS 3 og 2)}

De glaciale enheder, der har den største udbredelse inden for kortbladet, er aflejret i Mellem Weichsel (for 74 00029000 år siden) i den sidste del af den seneste istid, og i Sen Weichsel (for 29000 til ca. 11700 år siden, Fig. 6A). Enhederne repræsenterer kun dele af de nævnte tidsafsnit.

På trods af en god blotningsgrad er en opstilling og beskrivelse af nye formelle litostratigrafiske enheder og beskrivelse af de eksisterende samt påvisning af deres udbredelse en vanskelig opgave på grund af de omfattende glacialtektoniske forstyrrelser af aflejringerne. Imidlertid er de geologiske profiler med litologi, dannelse og alder i en del af klinterne velbeskrevet i videnskabelige publikationer fra de senere år, f.eks. Houmark-Nielsen (1994); Gravesen et al. (2017), og i rapporter og upublicerede specialeafhandlinger. Desuden har hydrogeologisk kortlægning (Rambøll 2006, 2007) bidraget til forståelsen af den geologiske opbygning og lagenes rumlige udbredelse i det indre af Møn, hvor der kun er få daglokaliteter. Disse informationer i kombination med kartering og undersøgelse af kystprofiler, profiler i råstofgrave, boredata og geofysik har bidraget til at underbygge opstillingen eller genbeskrivelsen af formationer fra Mellem og Sen Weichsel. Alle aldersangivelser er baseret på Houmark-Nielsen et al. (2017).

Ud fra udvalgte logs fra kystklinterne er der udarbejdet et længdeprofil, som kan følges fra Madses Klint langs Møns sydøst- og sydkyst til østkysten langs Møns Klint og videre mod nordøst til Hellehavn Nakke for at 
slutte på nordkysten ved Brunshoved (Fig. 8). Profilet viser den samlede litostratigrafiske opbygning med de forskellige enheders vertikale og horisontale udbredelse. De litologiske enheder og deres opdeling i formationer er beskrevet nedenfor.

\section{Ristinge Klint Till Formation (MIS 3)}

Navn og historie. Formationen har sit navn efter Ristinge Klint på Langeland. Det er en klassisk lokalitet, der har bidraget til forståelsen af Danmarks geologiske opbygning (Madsen et al. 1908; Madsen 1916). Andersen (1945) og Berthelsen (1973) kaldte morænelerenheden for den Gammel Baltiske Till. Houmark-Nielsen (1987) opstillede formelt formationen og gav en detaljeret beskrivelse af dens dannelseshistorie. Han påviste blandt andet, at moræneleret, der indeholder fingrus med en baltisk proveniens, blev aflejret i forbindelse med et isfremstød fra sydøst (Sjørring et al. 1982). På Møn er formationen ved Klintholm blevet betegnet som "Grey-red till, Unit 4" af Houmark-Nielsen (1994).

Typelokalitet. Typelokaliteten er Ristinge Klint på Langeland (Houmark-Nielsen 1987).

Litologi. Formationen består af moræneler med en grå eller rødgrå farve, og den rødlige farve skyldes et højt indhold af baltiske sandsten og kalksten fra Nedre Palæozoikum. Dens nedre del består ofte af båndet, gråt og hvidligt, glacialtektonisk udvalset moræneler med et højt indhold af opbrudt, shearet og foldet skrivekridt (Fig. 9; Banham 1977; Pedersen 1988). Den øvre del af moræneleret er rødgråt med rødligt sand og sandsten, som ofte kan findes på stranden foran klinterne. Et indhold af fingrus og klaster viser en baltisk dominans (Berthelsen et al. 1977; Hyde 1986; Houmark-Nielsen 1994; Stockmarr 1996; Smed 2010). I formationen findes undertiden omlejret Eem-materiale. På det nordøstlige Møn er der i klintprofilerne målt en till fabric, som viser en bred spredning omkring en østlig retning med et svagt til moderat dyk mod øst (50 målinger i Hyde 1986). Bortset fra, at moræneleret også her er påvirket af senere glacialtektonisk dislokation, viser målingerne en veldefineret isstrømsretning fra øst mod vest. Denne proveniens understøttes af fingrustællingen med $25 \%$ kalksten, hvoraf $2 / 3$ er palæozoiske, et lavt flintindhold (<5\%) og op til $15 \%$ sedimentære gruskorn, overvejende af sandsten (Hyde 1986). Jordartssymboler: ML, MS.

Grœenser og tykkelse. Ved Klintholm er den nedre grænse en glacialtektonisk inkonformitet på ældre, formodentlig Tidlig eller tidlig Mellem Weichsel-aflejringer. Ved Hvideklint og Hjelm Nakke hviler formationen ofte på skrivekridt. Den øvre grænse mod Kraneled Formationen er sedimentær og erosiv.

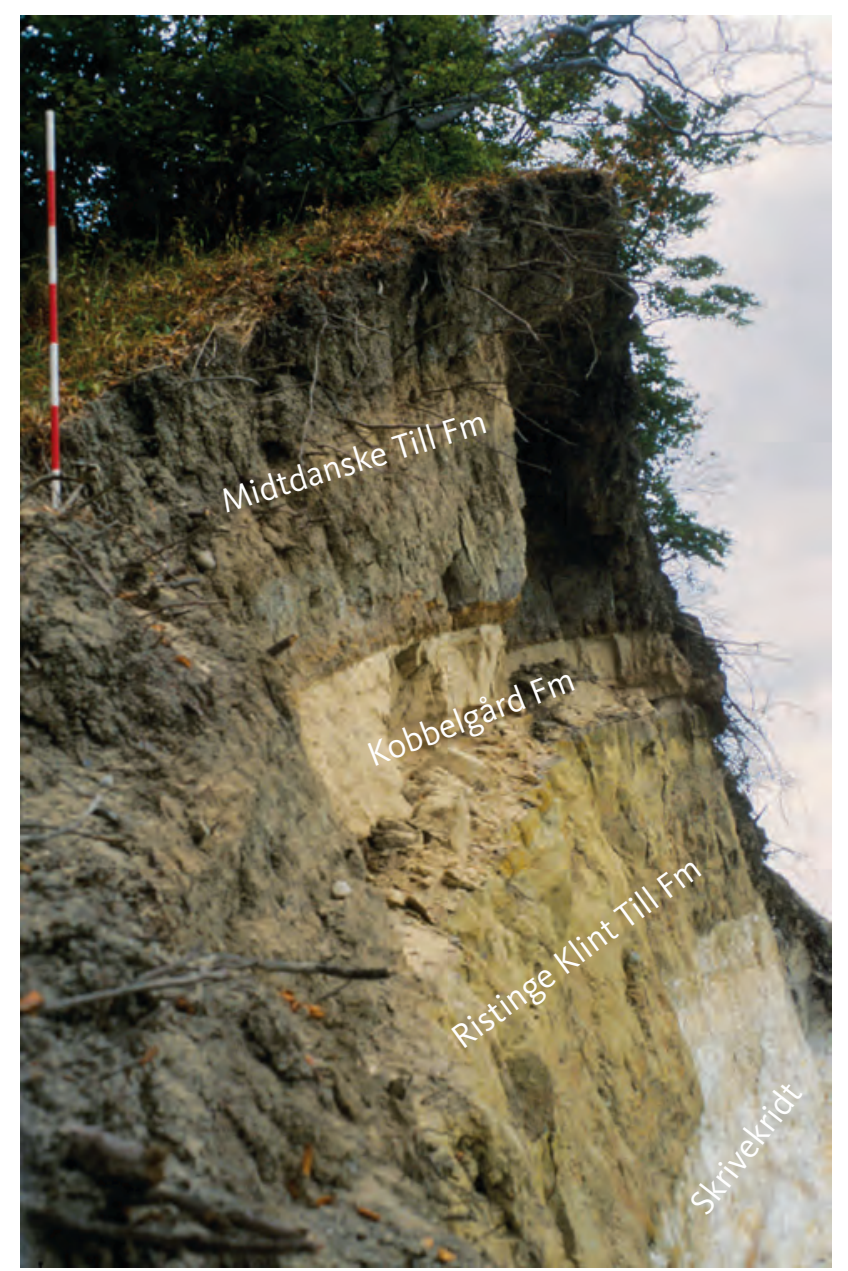

Fig. 9 Rødbrunt moræneler tilhørende Ristinge Klint Till Formationen ved Store Stejlebjerg. Formationen hviler på en inkonformitet på toppen af skrivekridt fra Møns Klint Formationen. Her i den sydlige del af Møns Klint overlejres Ristinge Klint Till Formationen af ler og fint sand tilhørende Kobbelgård Formationen. På toppen af lagserien findes moræneler fra den Midtdanske Till Formation. Landmålerstokkens enheder er $20 \mathrm{~cm}$ brede.

Fig. 9. Red-brown clayey till of the Ristinge Klint Till Formation at Store Stejlebjerg, Møns Klint. The formation rests unconformably on top of the Cretaceous chalk of the Møns Klint Formation. Finegrained lithologies of the Kobbelgård Formation overlie the Ristinge Klint Till Formation. At the top, clayey till of the Mid Danish Till Formation is present. For scale, the units on the ranging pole are 20 cm wide.

Formationens tykkelse er antagelig få meter ved Hvideklint - Hjelm Nakke, $4 \mathrm{~m}$ ved Klinthavn, $1 \mathrm{~m}$ ved Høje Møn, $3 \mathrm{~m}$ ved Hellehavn Nakke og $2 \mathrm{~m}$ ved Pomlerende (Hyde 1986; Houmark-Nielsen 1994; Stockmarr 1996).

Udbredelse og korrelation. Formationen er truffet på en række lokaliteter som ved Hjelm Nakke - Hvideklint (antagelig), Høje Møn, Klintholm, Hellehavn Nakke og Pomlerende, og dette antyder, at formationen har en større udbredelse på det sydlige og østlige Møn. 
Formationen har antagelig udbredelse i store dele af Danmark (Houmark-Nielsen 1987, 2007).

Alder. Formationen er aflejret i forbindelse med Ristinge Isfremstødet, som foregik for mellem ca. 55000 og 50000 år siden (Houmark-Nielsen 2010; HoumarkNielsen et al. 2017).

Aflejringsmiljø. Moræneleret er dannet som en bundmoræneaflejring. Indholdet af baltisk fingrus og klaster samt de glacialtektoniske strukturer viser, at bevægelsen af gletsjeren skete fra sydøst mod nordvest (Houmark-Nielsen 1999; Smed 2010). Denne isstrøm kaldes for Ristinge Isfremstødet (Det Gammelbaltiske Isfremstød, Houmark-Nielsen 1987; Houmark-Nielsen et al. 2017).

\section{Kraneled Formation (MIS 3)}

Ny formation
Navn og historie. Kraneled Formationen har navn efter lokaliteten Kraneled øst for Klintholm på sydlige Møn (Fig. 6B). Houmark-Nielsen (1994) betegnede den som "Glaciofluvial and lacustrine deposits, Unit 5", mens den i Houmark-Nielsen \& Kjær (2003) blev angivet som "Klintholm Beds" og i Houmark-Nielsen et al. (2017) som "Klintholm".

Typelokalitet - og profil. Typelokaliteten er ved Kraneled Klint øst for Klintholm (Fig. 10; Houmark-Nielsen 1988, 1994). Typeprofilet ses i Houmark-Nielsen (1994, fig. 5, Unit 5).

Litologi. Den nedre del består af krydslejret og imbrikeret sand og grus. Den øvre del er opbygget af krydslejret sand, som fortsætter i finkornet sand og horisontalt lamineret ler (Fig. 10). Der kan være få planterester. Jordartssymboler: DL, DS, DG.

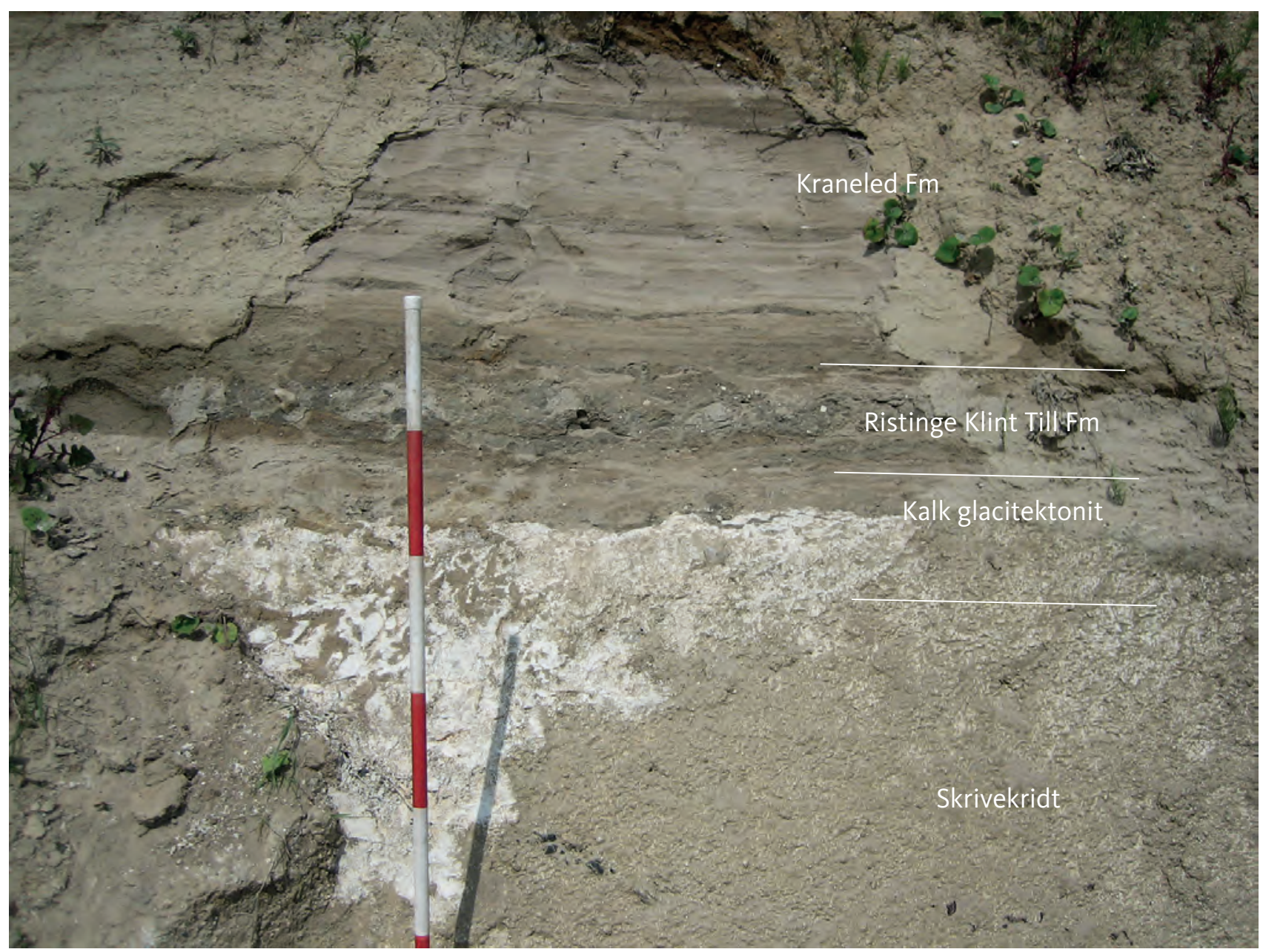

Fig. 10 Finkornede smeltevandsaflejringer tilhørende Kraneled Formationen, hvilende på Ristinge Klint Till Formationen. En skrivekridt-glacitektonit ses ved formationens basis langs toppen af skrivekridtet. Klinten ved Kraneled, Klintholm.

Fig. 10. Fine-grained meltwater deposits of the Kraneled Formation resting on the Ristinge Klint Till Formation. Between the till and the underlying chalk, a chalk-g/acitectonite occurs. Kraneled cliff, Klintholm. 
Grænser og tykkelse. Den nedre grænse til Ristinge Klint Till Formationen er en skarp, erosiv grænse. Den øvre grænse er en gradvis sedimentær overgang til Klintholm Till Formationen.

Formationens tykkelse er omkring $4 \mathrm{~m}$ ved Klintholm og $2 \mathrm{~m}$ ved Tøvelde Klint, men større på det vestlige Møn (omkring $7 \mathrm{~m}$ i boringer).

Udbredelse og korrelation. Blotningsgraden er ikke god, så det er vanskeligt at fastslå formationens udbredelse. Den træffes i Hjelm Bugt og på Vestmøn.

Undersøgelser ved boringer på Kriegers Flak i Østersøen øst for Møn viser en interstadial søaflejring fra et tidsrum (for 40 000-35 000 år siden) antagelig svarende til Kraneled Formationen (Anjar et al. 2010, 2012). Samtidige aflejringer findes også inden for det store issøområde ved Brorfelde, hvor der i tykke sandlag er fundet stødtænder af mammut, som er dateret til ca. 44000 år før nu (Selsing 1982).

Interstadiale aflejringer på Sejerø er dateret til omkring 36000 år før nu, hvilket placerer dem før Klintholm Till Formationen og antagelig samtidig med lagene fra Kraneled Formationen. Planteindholdet i de lakustrine aflejringer på Sejerø peger på et åbent, træløst land med tundravegetation (Kolstrup \& Houmark-Nielsen 1991; Bennike et al. 2007). Den finkornede del af Kraneled Formationen kan repræsentere det samme aflejringsmiljø som på Møn under Sandnæs Mildningen.

Alder. Formationen har en alder på ca. 45 000-35 000 år før nu (Houmark-Nielsen et al. 2017) og er således formodentlig dannet under den første fase af Sandnæs Mildningen.

Aflejringsmiljø. De nederste, grovkornede lag er glaciofluviale aflejringer, som antageligt er afsat i en smeltevandsflod i et periglacialt område. Fortsættelsen opad peger på dannelse i et lakustrint aflejringsmiljø. Landskabet må forventes at have været åbent med beskeden tundravegetation under arktiske forhold.

\section{Klintholm Till Formation (MIS 3)}

Justeret formation

Navn og historie. Formationen har navn efter den lille by Klintholm på sydkysten af Møn. Den er beskrevet af Houmark-Nielsen (1994) som "Thick grey diamicton" og af Krüger og Kjær (1999) som "Unit 6". Sidenhen er till-aflejringen blevet betegnet som Klintholm Till (Houmark-Nielsen \& Kjær 2003; Houmark-Nielsen 2008, 2010; Houmark-Nielsen et al. 2016).

Typelokalitet og -profil. Typelokaliteten og typeprofilet er Kraneled øst for Klintholm, mens et referenceprofil ses ved Kobbelgård vest for Klintholm (Fig. 11; HoumarkNielsen 1988, 1994, fig. 5, unit 6).

Litologi. Klintholm Till Formationen består af gråt, massivt, siltet og sandet moræneler med et moderat indhold af spredte klaster (Fig. 6, 11). Øverst kan der optræde mørkebrunt, massivt moræneler, der stedvis er lagdelt. Der træffes stedvis omlejrede skaller eller skalfragmenter af marine mollusker fra Eem. Jordartssymboler:

\section{ML, MS.}

Grœenser og tykkelse. Formationens tykkelse er ca. 2,6 m ved Madses Klint, 3,6 m ved Hjelm Nakke - Hvideklint, $4 \mathrm{~m}$ ved Tøvelde Klint, 3-5 m ved Klintholm, $3 \mathrm{~m}$ ved Møns Klint, ca. 1,5 m ved Hellehavn Nakke og 1,8 m ved Stubberup Have (Hyde 1986; Houmark-Nielsen 1994; Stockmarr 1996; Gravesen et al. 2017).

Klintholm Till Formationens nedre grænse er en gradvis overgang fra leret moræneler til sand og mudder $\mathrm{i}$ Kraneled Formationen, men denne grænse er undertiden også en glacialtektonisk inkonformitet. Den øvre grænse er gradvis fra moræneler til mudder i Kobbelgård Formationen.

Udbredelse og korrelation. Klintholm Till Formationen har stor udbredelse fra Møn til Falster (Korselitse) og videre over Sydsjælland (Houmark-Nielsen 2010).

Alder. Klintholm Till Formationen er aflejret under Klintholm Isfremstødet, som har en alder på ca. 35000 32000 år før nu (Houmark-Nielsen 2010; HoumarkNielsen et al. 2017).

Aflejringsmiljø. Formationens morænelersaflejringer er afsat af en gletsjer, som har bevæget sig fra sydøst mod nordvest. Dette kan demonstreres ved fingrustællinger og 'klast fabric' orienteringsmålinger samt glacialtektoniske strukturer. Smed (2010) har analyseret klastindholdet ved stentælling, og dette viser, at en del af gletsjerbevægelsen har været omtrent fra nordøst mod sydvest gennem Sverige, hvorefter retningen ændredes til vestlig mod Danmark (se også Ukkonen et al. 2007). Aflejringen anses for at være for at være sket langs bunden af gletsjeren (bundmoræneaflejring). Isfremstødet betegnes af Houmark-Nielsen et al. (2017) som Klintholm Isstrømmen.

\section{Kobbelgård Formation (MIS 3) \\ Ny formation}

Navn og historie. Kobbelgård Formationen er navngivet efter Kobbelgård klint, som ligger ved Hjelm Bugt på det sydlige Møn, hvor der er truffet interstadiale lakustrine aflejringer samt glaciolakustrine og -fluviale aflejringer. 


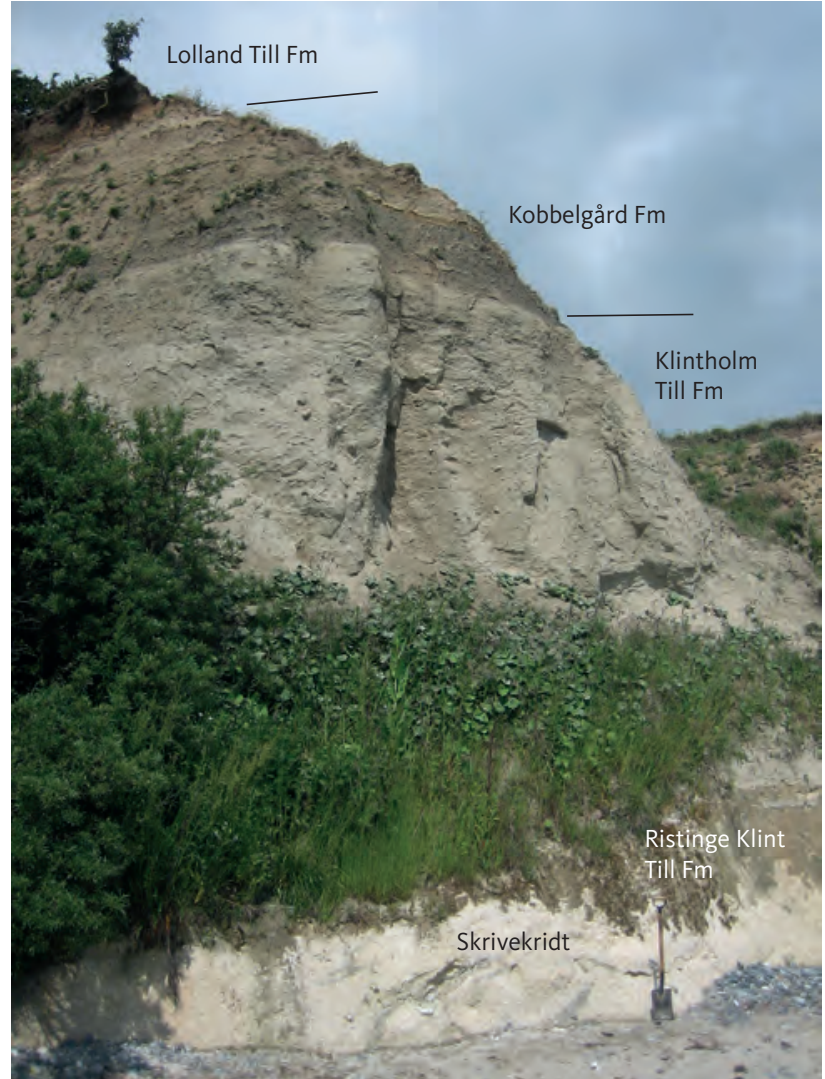

Fig. 11 Gråt moræneler tilhørende Klintholm Till Formationen i klinten ved Kraneled, Klintholm. I profilet ses desuden aflejringer af skrivekridt og Ristinge Klint Till, Kobbelgård og Lolland Till Formationerne.

Fig. 11. Grey clayey till of the Klintholm Till Formation at Kraneled cliff, Klintholm. The section also contains deposits of chalk as well as deposits of the Ristinge Klint Till, Kobbelgard and Lolland Till Formations.

Aflejringerne er især godt undersøgt omkring Klintholm Havn i de to klinter ved Kobbelgård og Kraneled (Houmark-Nielsen 1988, 1994, 2003, 2010; Krüger \& Kjær 1999; Houmark-Nielsen et al. 2016), hvor en lagfølge, som også omfatter Klintholm Till og Kraneled Formationerne (Fig. 8), er detaljeret beskrevet og tolket ud fra aldersbestemmelser, sedimentologi og indholdet af plante- og dyrefossiler.

Den nedre del af leraflejringerne er kendt fra en række tidlige undersøgelser på Møn (f.eks. Puggaard 1851; Hintze 1937; Hansen \& Nielsen 1960; Berthelsen et al. 1977) som en leraflejring med et beskedent klastindhold ("Stenfattigt ler", Hyde 1986). Et karakteristisk sprækkesystem ("søjleforkløftning", Berthelsen et al. 1977) har givet ophav til navnet 'elefantfodleret' på grund af, at uderoderede og ofte foldede partier af leret har lighed med en elefants fødder. Ved Klintholm er lagene beskrevet som "Lower lake sediments, Unit 7" af Houmark-Nielsen (1994) og som en del af "Upper Kobbelgård Beds" i Houmark-Nielsen et al. (2016).
Den øvre del af formationen omfatter overvejende den fossilrige del af søaflejringerne ved Klintholm, som består af ler, silt og diamikte aflejringer. De er beskrevet af Houmark-Nielsen (1994) som "Upper lake sediments, Unit 8", "Upper Kobbelgård beds " og "Kobbelgård Beds" (Houmark-Nielsen \& Kjær 2003; Houmark-Nielsen 2010). Aflejringerne er også beskrevet af Krüger \& Kjær (1999).

Typelokalitet og profil. Typelokaliteten for Kobbelgård Formationen er ved Kobbelgård Klint vest for Klintholm Havn og Kraneled Klint øst for, hvor der er opmålt flere delprofiler (se Houmark-Nielsen 1994 fig. 5, Unit 7, Unit 8; Houmark-Nielsen 1988, 1994; Krüger \& Kjær 1999).

Litologi. Formationen består nederst af ler/mudder med tynde sandlag og mange spredte klaster (Fig. 12), og leraflejringen er gennemsat af talrige sprækker. Ved basis findes stedvis krydslejret og horisontalt lagdelt sand, undertiden med omlejrede skaller fra Eem-aflejringer.

Leret er fedt og siltet, kalkholdigt og mørkegråt, med tynde sandlag og ofte spredte klaster. Indholdet af silt og ler er 90-94\%, resten er sand og fint grus (Hyde 1986). Fingrusindholdet er helt domineret af palæozoiske kalksten (Hyde 1986). Foruden sprækkesystemer er der kun fundet strukturer i form af en vanskeligt genkendelig og utydelig lagdeling i leraflejringerne. Der er spredte planteaflejringer i form af blade og plantedetritus. Desuden er der fundet pollen fra en arktisk fauna (Kolstrup \& Houmark-Nielsen 1991).

Formationens øvre del består af en række vekslende, massive ler- og siltlag samt diskontinuerlige lag af finkornet sand med indslag af lerede diamikte lag mod toppen (Fig. 13). Lagene indeholder fragmenter af planter inkl. blade og finkornet detritus, og der er beskrevet en omfattende terrestrisk mikro- og makroflora (Kolstrup \& Houmark-Nielsen 1991; Bennike et al. 1994, 2007). Klaster og fingrus i de diamikte aflejringer er domineret af palæozoiske kalksten og skifre. De øverste lag indeholder imidlertid en blanding af lokale og baltiske bjergartsfragmenter. Jordartssymboler: DL, DI, DS, ML.

Groenser og tykkelse. Formationens nedre grænse til Klitholm Till Formationen er oftest gradvis. Den øvre grænse til den Midtdanske Till Formation er en glacialtektonisk inkonformitet. Kobbelgård Formationens tykkelse kan nå helt op på 15 m ved Klintholm, men varierer ved andre klinter med følgende ca.-værdier: Madses Klint: 7,5 m, Hjelm Nakke - Hvideklint: 12,5 m, Tøvelde Klint: 7,5 m, Møns Klint: $12 \mathrm{~m}$, Liselund: $5 \mathrm{~m}$, Hellehavn Nakke: 11 m, og Stubberup Have: 7 m (Ødum 1933; Hintze 1937; Hyde 1986; Houmark-Nielsen 1988, 1994; Stockmarr 1996; Houmark-Nielsen et al. 2016; Gravesen et al. 2017). 


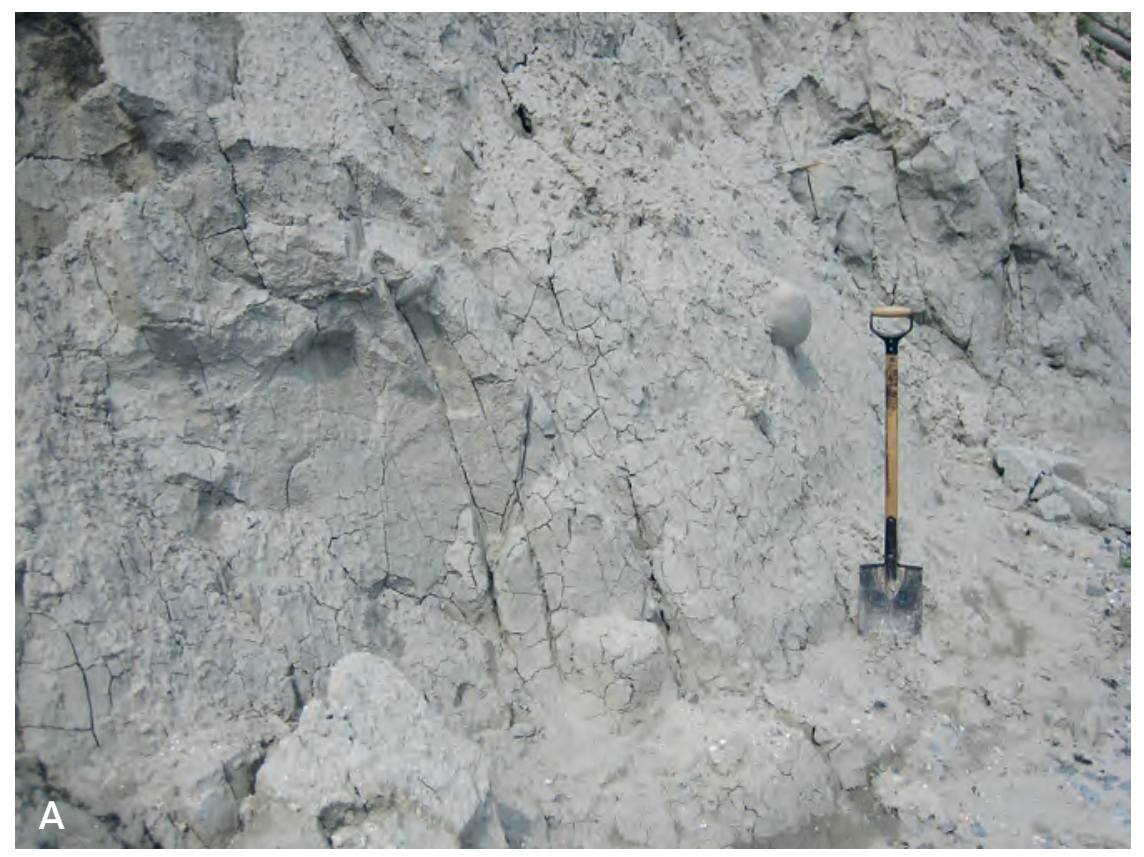

Fig. 12 Lakustrine aflejringer af gråt, siltholdigt ler med få gruskorn og sten tilhørende Kobbelgård Formationen. A: Typisk glaciolakustrint ler med få spredte dropsten. Klinten ved Liselund. B: Ler ved foden af jordskredskomplekset neden for Liselund.

Fig. 12. Lacustrine deposits of grey, silty clay with scattered pebbles of the Kobbelgård Formation. A: Typical glaciolacustrine clay with widely spaced dropstones. B: Clay at Liselund in the dislocation horizon at the toe of a landslide.

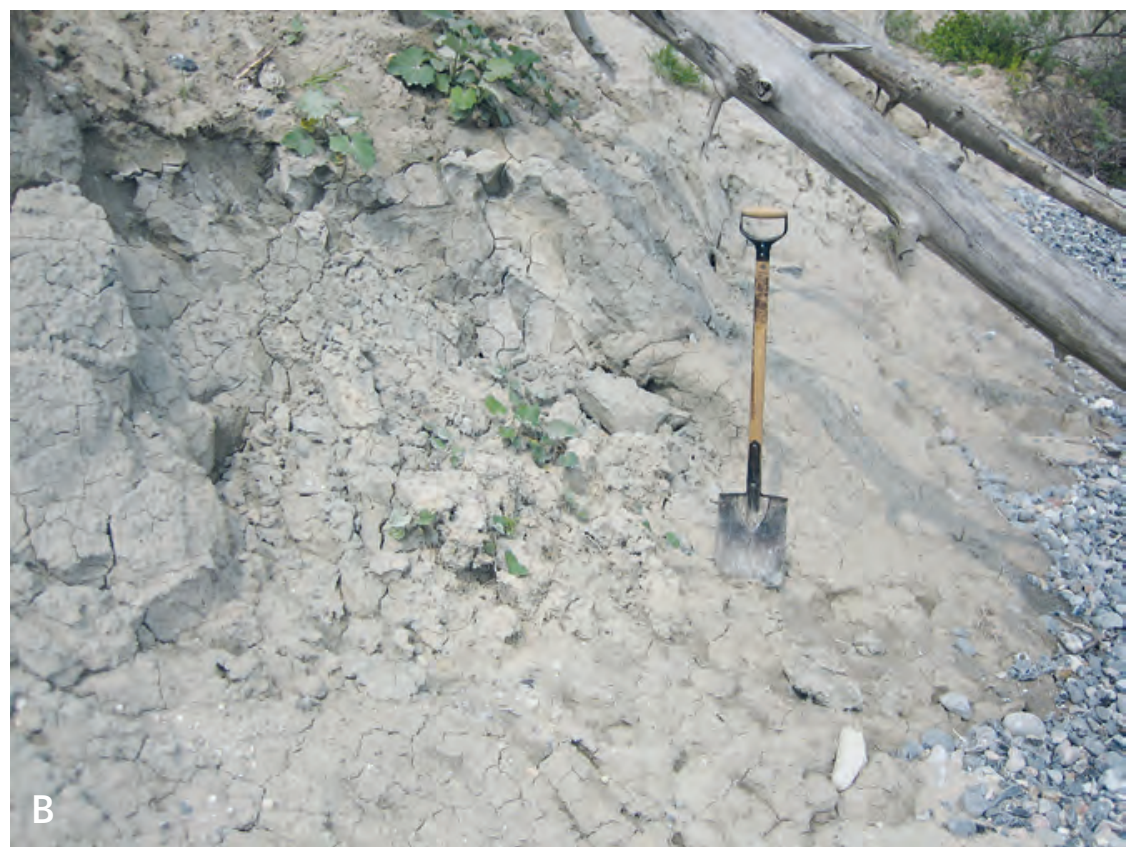

Udbredelse og korrelation. Formationen har stor udbredelse på det sydlige, østlige og nordøstlige Møn. Den øvre fossilrige del træffes især på sydkysten. Dele af formationen er sandsynligvis samtidige med aflejringer på Kriegers Flak (Anjar et al. 2010, 2012). Desuden findes formationen langs Falsters østkyst, bl.a. ved Korselitse (Houmark-Nielsen 2010; Gravesen et al. 2017).

Alder. Aflejringerne er fra Mellem Weichsel, MIS 3. Formationen hviler på Klintholm Till Formationen, som har en alder på 35 000-32 000 år før nu (Houmark-Nielsen et al. 2017).

Der er foretaget en række ${ }^{14} \mathrm{C}$-, OSL- og TL-aldersbestemmelser på plantemateriale og sedimenter fra Kobbelgård
Formationen, som giver en spredning over den sidste del af Mellem Weichsel. Formationen er således dateret til 35 000-20 000 år ved OSL-metoden og mellem 37 00025000 år ved ${ }^{14} \mathrm{C}$-metoden (Houmark-Nielsen 2010).

Dateringerne fra Klintholm-området antyder tilsammen, at det sandsynlige aldersinterval ligger mellem 32000 og 28000 år før nu (Houmark-Nielsen \& Kjær 2003; Houmark-Nielsen 2008, 2010; Houmark-Nielsen et al. 2016; Houmark-Nielsen et al. 2017).

Formationen har en alder på ca. 32 000-28 000 år og repræsenterer en lakustrin aflejring fra den sidste del af Sandnæs Mildningen (Houmark-Nielsen et al. 2017).

Aflejringsmiljø. Ved slutningen af den kolde periode for 


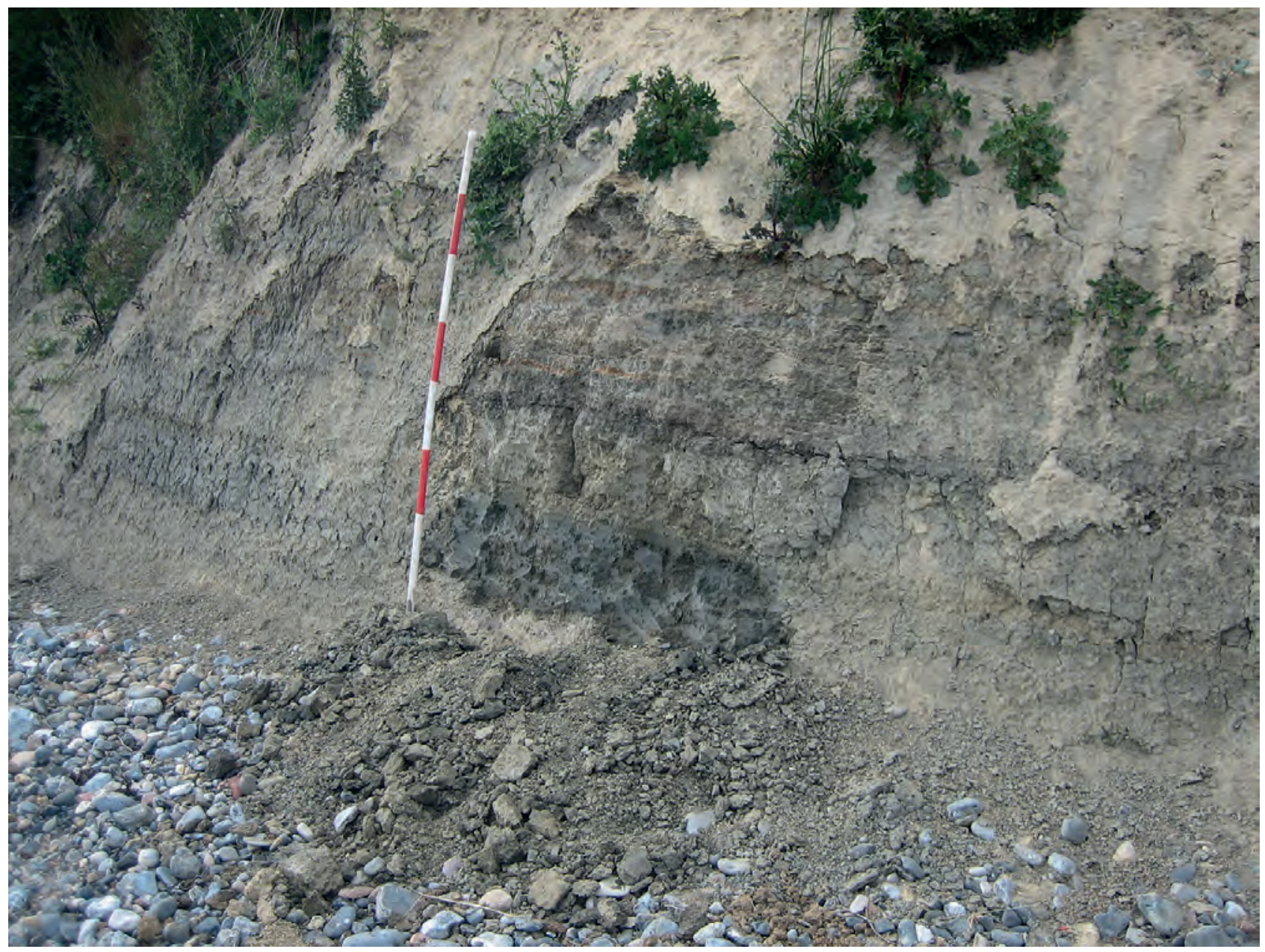

Fig. 13 Gråt, siltet og fedt, lagdelt ler tilhørende Kobbelgård Formationen. Klinten ved Kobbelgård, Klintholm. Landmålerstokkens enheder er $20 \mathrm{~cm}$ brede.

Fig. 13. Grey, silty and fine-grained, horizontally laminated clay of the Kobbelgård Formation. Kobbelgård cliff, Klintholm. For scale, the units on the ranging pole are $20 \mathrm{~cm}$ wide.

ca. 32000 år siden, da Klintholm Isfremstødet, som aflejrede Klitholm Till Formationen, smeltede væk, blev der dannet en stor iss $\emptyset$, der var udbredt over hele den sydlige, østlige og nordlige del af Møn og måske endog over et større område omkring Østersøen, hvilket også er blevet foreslået af Hansen (1965) og Houmark-Nielsen (1994). I starten blev der aflejret sand og grus, hvor smeltevand strømmede ind i søen. Derefter var der udstrakt aflejring af ler og silt, og isflager bragte klastmateriale ud i søen, der blev aflejret som dropsten. I det vegetationsløse landskab blev finkornet sand blæst ud i søen og aflejret i tynde lag. I takt med, at klimaet blev varmere, og tilførsel af smeltevand fra den baltiske is blev formindsket, blev søen gradvis mindre. Efterhånden bredte en arktisk vegetation sig omkring søen med græs og urter samt enkelte små træer som fyr og birk.

I den sidste del af perioden for ca. 30 000-28 000 år siden var søen sandsynligvis indskrænket til at dække et område omkring Klintholm. Mudder (ler, silt og fint sand) blev aflejret fra suspension, mens de diamikte lag er dannet ved mudderstrømme, der er gledet ud i søen, eller som stammer fra isflager. Også vindblæst fint sand og silt er påvist (Houmark-Nielsen 1994; Krüger \& Kjær1999). Vegetationen omkring søen var subarktisk uden træer, men med urter og mange buske. Det stadigt varmere subarktiske klima medvirkede til, at plantevækst bredte sig i og omkring søen. Flodsystemer omkring søen aflejrede lateralt herfor krydslejrede, finkornede banker, og floder førte sandet og gruset materiale ud i søen (Stubberup Have Formationen).

Fund af en mammuttand ved Slotshøj, Stege Nor (Aaris-Sørensen et al. 1990) kan indikere tilstedeværelsen af en større græsslette omkring søen. På dette tidspunkt har større græs- og urtestepper med mammutter og andre større dyr eksisteret i Danmark (Aaris-Sørensen et al. 1990) og det sydlige Sverige (Berglund et al. 1976; Ukkonen et al. 2007). 


\section{Stubberup Have Formation (MIS 3)}

Ny formation

Navn og historie. Formationen har navn efter den nordlige del af Møns Klint fra området ved Stubberup Have.

Typelokalitet og -profil. Typeprofil og -lokalitet er Stubberup Have (Fig. 14; Hyde 1986).

Litologi. Formationen består af sand og grus samt undertiden sten (Fig. 8, 14). Sedimentære strukturer forekommer som ribber og storskala krydslejring, horisontal lagdeling og grovkornede kanaler med grus og sten, som skærer ned i de underliggende sandlag. Finkornet, velsorteret sand og silt med klatrende ribber træffes også.

Grcenser og tykkelse. Tykkelsen af Stubberup Have Formationen varierer en hel del (Fig. 8). Følgende er registreret i klinterne: Madses Klint: 1,3 m, Hjelm Nakke - Hvideklint: 4,5 m, Tøvelde Klint: 5 m, Møns Klint: 1,4 m, Liselund: 10 m, Hellehavn Nakke: 11 m og Pomlerende:
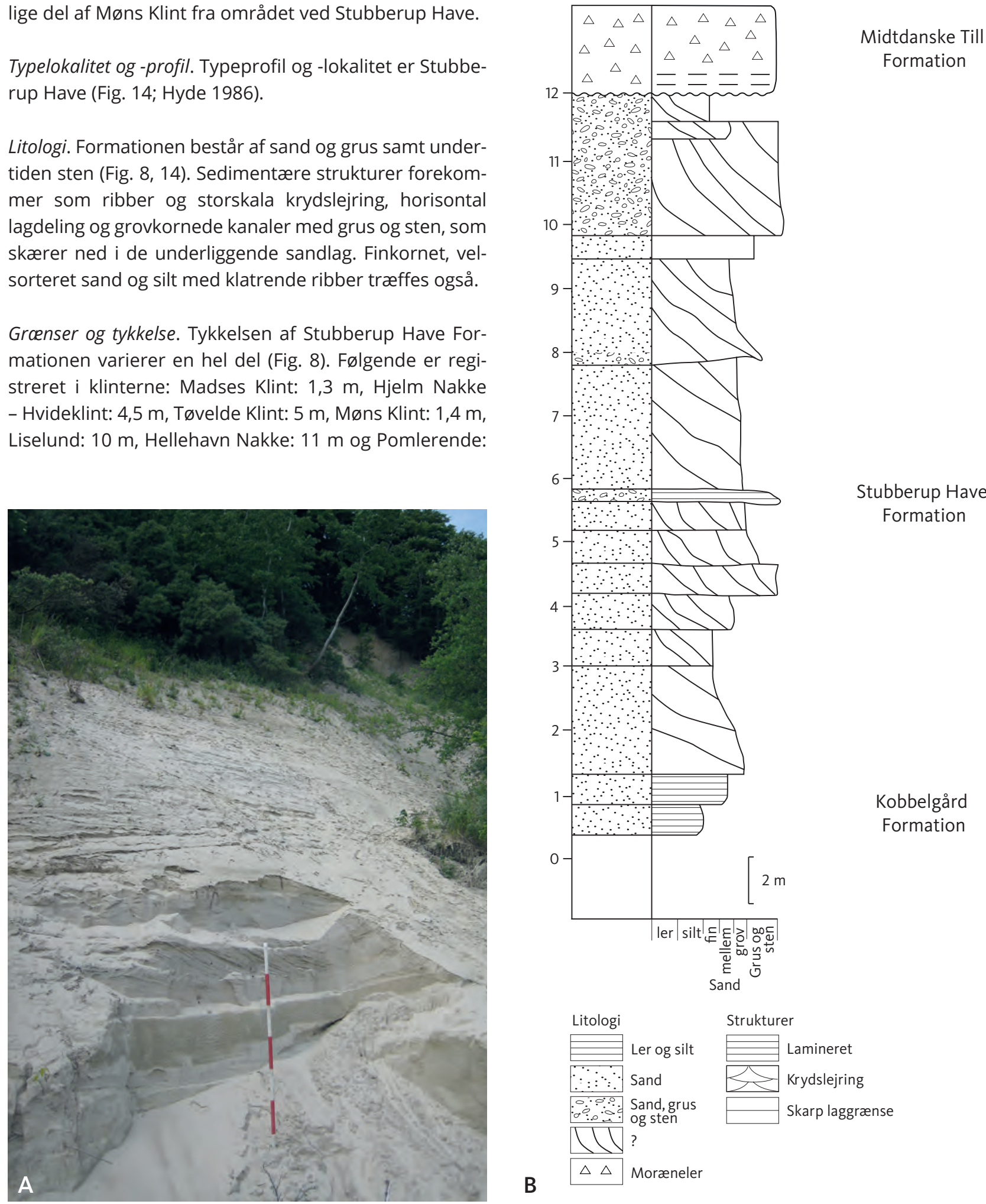
Formation

Stubberup Have Formation

Kobbelgård Formation

B

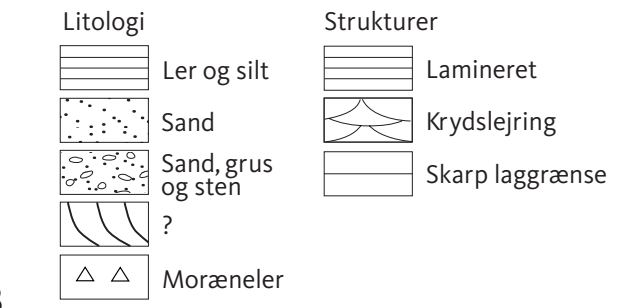

Fig. 14 A: Mellem- og grovkornet, krydslejret sand tilhørende Stubberup Have Formationen. Klinten ved Stubberup Have, typelokalitet for formationen. Landmålerstokkens enheder er $20 \mathrm{~cm}$ brede. B: Sedimentologisk log for Stubberup Have Formationen.

Fig. 14. A: Medium- and coarse-grained, cross-bedded sand of the Stubberup Have Formation at the cliff of Stubberup Have, the type locality for the formation. The units on the ranging pole are $20 \mathrm{~cm}$ wide. B: Sedimentological log of the Stubberup Have Formation. 


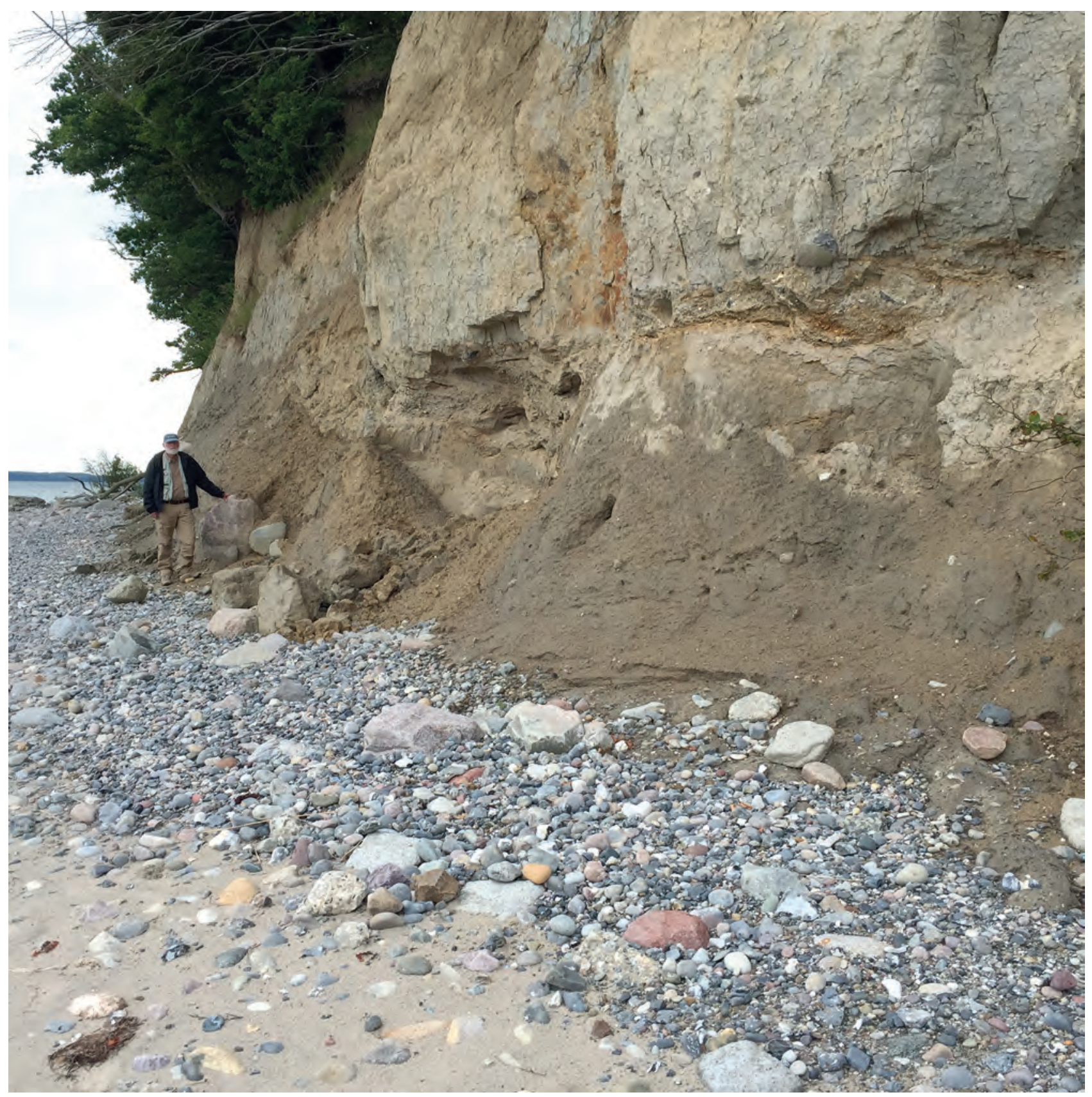

Fig. 15 Gråt moræneler tilhørende den Midtdanske Till Formation. Madses Klint.

Fig. 15. Grey clayey till of the Mid Danish Till Formation, Madses Klint.

mindst 3 m (Hintze 1937; Hyde 1986; Stockmarr 1996; Gravesen et al. 2017). Enkelte boringer peger på en tykkelse på op til 20 m, hvor lagene dog kan være glacialtektonisk forstyrrede.

Formationen har en skarp, nedre sedimentær grænse til Kobbelgård Formationen (Fig. 8). Mod vest fra Tøvelde og Klintholm klinterne til Madses Klint er grænsen til Kobbelgård Formationen formodentlig sammenflettet. Den øvre grænse til den Midtdanske Till Formation er er en skarp glacialtektonisk inkonformitet.
Udbredelse og korrelation. Stubberup Have Formationen er udbredt på store dele af Møn.

Alder. Stubberup Have Formationens alder er formentlig delvis den samme som Kobbelgård Formationens (32 000-28 000 år; Houmark-Nielsen et al. 2017).

Aflejringsmiljø. Aflejringsmiljøet var en slette med flettede floder, som har dannet små ribber og større banker. Der har også stedvis været lakustrine forhold med aflejing af fint sand og silt under stor materialetilførsel. 


\section{Midtdanske Till Formation (MIS 2)}

Navn og historie. Den Midtdanske Till Formation (Mid Danish Till Formation) blev opstillet af Houmark-Nielsen (1987) for den litologiske enhed af moræneler, der dækker Danmark fra landets østlige grænse mod vest til Hovedopholdslinjen i den centrale del af Jylland. Formationen har typelokalitet i Ristinge Klint på Langeland, hvor den danner en ca. 15 m tyk, homogen litologisk enhed i de flager, som indgår i det glacialtektoniske kompleks i Ristinge Klint. Baggrunden for opstillingen af formationen findes i Houmark-Nielsen (1987).

Typelokalitet og referenceprofil. Typelokalitet og -profil er Ristinge Klint på Langeland (Houmark-Nielsen 1987). Referenceprofilet på Møn er ved Madses Klint (Fig. 15).

Litologi. Formationen består af massivt, kalkholdigt moræneler. Der er ofte et højt indhold af kalkklaster. Kalkindholdet i de glacialtektonisk påvirkede dele af moræneleret klassificerer disse dele som glacitektoniter (Pedersen et al. 2018). Jordartssymbol: ML.

Groenser og tykkelse. Midtdanske Till Formation har på Møn en tykkelse på op til 10 m, men tykkelsen varierer i øvrigt meget. I klinterne træffes følgende tykkelser: Madses Klint: 3,5 m, Hjelm Nakke - Hvideklint: 6 m, Tøvelde: 4 m, Møns Klint: 9 m, Liselund: 3 m, Pomlerende: varierende tykkelse, Stubberup Have: 5,5 m og Brunshoved: 8 m. (Ødum 1933; Hansen \& Nielsen 1960; Berthelsen et al. 1977; Hyde 1986; Stockmarr 1996; Gravesen et al. 2017).

Formationen overlejrer Stubberup Have Formationen med en skarp grænse, almindeligvis med en glacialtektonisk inkonformitet (Fig. 6), og overlejres af Ny Borre Formationen med en skarp sedimentær grænse.

Udbredelse og korrelation. Formationen findes på hele Møn undtagen i Klintholm-området.

Alder. Alderen er ca. 23 000-20 000 år før nu (HoumarkNielsen et al. 2017). Formationen er aflejret under det sidste glaciale maksimum i Weichsel ('Late Glacial Maximum', LGM).

Aflejringsmiljø. Den Midtdanske Till Formation er en bundmoræne (lodgement till) aflejret af en gletsjer. Glacialtektoniske retningsindikatorer, klastindhold og fingrustællinger viser, at gletsjeren har bevæget sig fra nordøst mod sydvest (Berthelsen et al. 1977; Aber 1979; Hyde 1986; Stockmarr 1996; Smed 2010).

Formationen er aflejret under den maksimale udbredelse af den Skandinaviske Iskappe i sidste del af Weichsel-istiden. Hovedopholdslinjen for dette isfremstød var beliggende $100 \mathrm{~km}$ syd og vest for Møn i et strøg fra Flensborg og nord om Hamburg til Brandenburg, hvorfra den drejede syd om Berlin og ind i det nordlige Polen, den såkaldte Brandenburg Israndslinje (Smed \& Ehlers 2002; Ehlers et al. 2004).

\section{Ny Borre Formation (MIS 2) \\ Ny formation}

Navn og historie. Formationen er opkaldt efter landsbyen Ny Borre syd for Borre på Østmøn. Formationen inkluderer de overfladenære glaciofluviale og -lakustrine sand- og grusaflejringer, som kan træffes over store dele af Møn. Disse lag har ikke tidligere været navngivet. Der indvindes sand og grus fra formationen i bl.a. Ny Borre grusgrav.

Typelokalitet og -profil. Typelokaliteten findes i den aktive grusgrav i Ny Borre. Typeprofilet kan ses på Fig. 16, der viser en lagfølge af sand med indhold af både grov- og finkornede aflejringer.

Litologi. Formationen består af lagdelte silt-, sand- og gruslag med stor udbredelse på Møn. Kornstørrelsen i formationen kan variere en hel del alt efter den sammenhæng, som lagene findes i. Den nederste del består af finkornet og mellemkornet sand samt silt i vekslende lag med linser af grovere sand. Undertiden indgår lerlag. Lagene hælder stedvis og kan være dele af kanaler eller større, hældende forsæt, som viser en strømretning
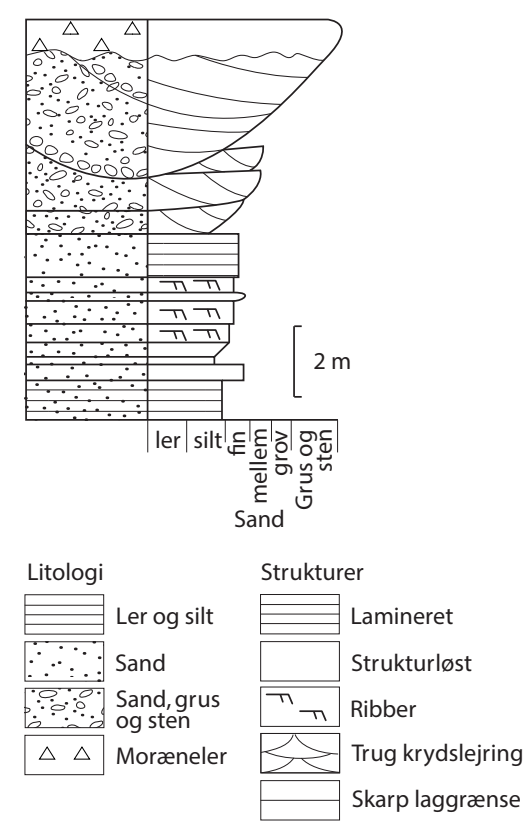

Fig. 16 Sedimentologisk log af Ny Borre Formationens fluvialelakustrine sekvens på typelokaliteten i Ny Borre grusgrav.

Fig. 16. Sedimentological log of the fluvial-lacustrine sequence of the Ny Borre Formation at the type locality in the Ny Borre gravel pit. 


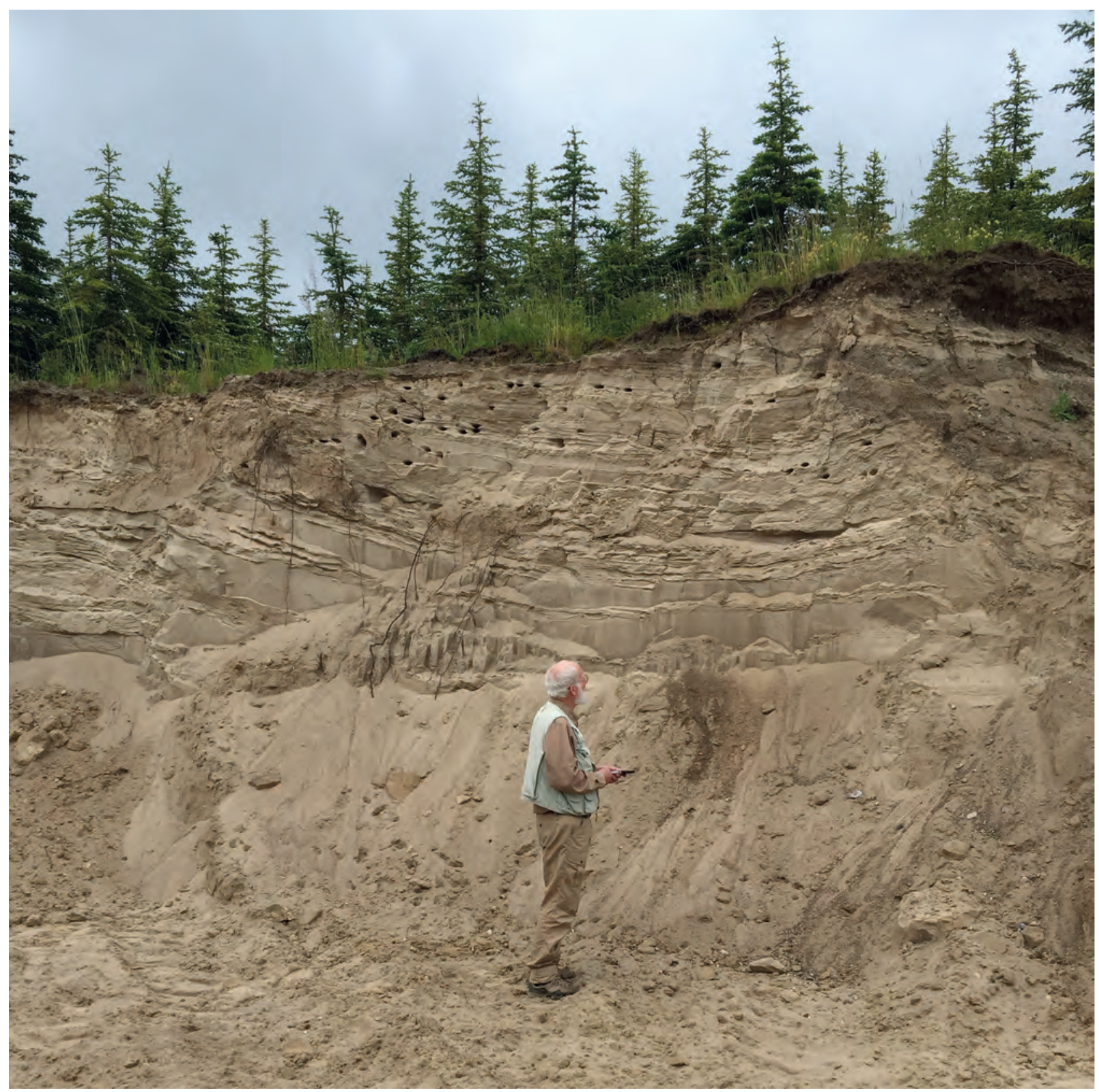

Fig. 17 Hældende, vekslende silt-, sand- og gruslag i en lakustrin lagfølge fra Ny Borre Formationen. Ny Borre grusgrav.

Fig. 17. Inclined, alternating silt, sand and gravel layers in a lacustrine sequence of the Ny Borre Formation. Ny Borre gravel pit.

fra syd og sydvest (Fig. 17). Den øvre del, som har størst udbredelse, består af krydslejret, grovere sand med gruslag, som forefindes i større kanalstrukturer. Jordartssymboler: DS, DG, DI, FS, FG.

Granser og tykkelse. Formationens nedre grænse mod den Midtdanske Till Formation er skarp og overvejende sedimentær. Den kan ses ved de samme lokaliteter som den øvre grænse.

Formationens øvre grænse til Lolland Till Formationen er ligeledes skarp og ofte en glacialtektonisk inkonformitet. Grænsen kan træffes i en række kystklinter, bl.a. i
Madses Klint, Hjelm Nakke, Hvideklint, Tøvelde, Møns Klint og i klinterne nord for Høje Møn (Liselund, Stubberup Have og Pomlerende). Formationens tykkelse varierer 5-10 m på store dele af øen, men kan være tykkere i de store kanaler. På typelokaliteten i Ny Borre grusgrav er tykkelsen ca. 6 m (Storstrøms amt 2004; Region Sjælland 2012). Variationen af formationens tykkelse i klinterne, hvor den er overlejret af Lolland Till Formationen, er: Madses Klint 12 m, Hvide Klint: 6 m, Tøvelde: 1,5 m, Møns Klint: 5,5 m, Liselund: mindst 4,5 m, Pomlerende: op til 3 m og Stubberup Have: 5,5 m (Hintze 1937; Hyde 1986; Stockmarr 1996). 
Udbredelse og korrelation. Formationen er udbredt på store dele af Møn og ses på det geologiske kort i overfladen eller lige under Lolland Till Formationen. Dette kan også ses i Rambøll (2006). Formationen følger her en række dalstrukturer fra nord til syd omfattende Borre Sømose, Maglemose, Klostervig lavningen omkring Stege Nor, Røddinge lavningen og Fanefjord, som alle er tunneldale eller afvandingskanaler fra smeltningen af den Ungbaltiske Is. I en formodet tunneldal fra Kobbelgård til Stege Nor træffes Råbylille Ås, og i Fanefjord tunneldalen findes Fanefjord Ås (Smed 2014). I begge tunneldale træffes en del af formationens sedimenter. I hatformede bakker på det sydvestlige Møn træffes formationen også (Berthelsen 1980).

Alder. Ny Borre Formationen anses for at være aflejret under fremrykningen af den Ungbaltiske Is. Disse begivenheder antages at have foregået for 19 00018000 år siden (Houmark-Nielsen et al. 2017).

Aflejringsmiljø. Formationen repræsenterer flere forskellige successive aflejringsmiljøer dannet af smeltevand fra den Ungbaltiske Is, nemlig et glaciofluvialt aflejringsmiljø, hvor sand og grus aflejredes på dal-sandurer, der udvikledes i en række store afvandingskanaler eroderet ned i den Midtdanske Till Formation, og et glaciolacustrint miljø, hvor smeltevandsaflejringerne blev aflejret i mere eller mindre isdæmmede langsøer vinkelret på isranden. Sand- og gruslag er også aflejret i overfladenære åse og hatformede bakker.

\section{Lolland Till Formation (MIS 2)}

Navn og historie. Lolland Till Formation er opkaldt efter Lolland i det sydøstlige Danmark og blev opstillet i forbindelse med beskrivelsen af kortbladet Sakskøbing (Pedersen et al. 2015). Det moræneler, som dækker landskaberne i den sydøstlige del af Danmark, bliver traditionelt henført til den bundmoræne, som blev afsat af det Ungbaltiske Isfremstød. Denne aflejring af moræneler har i det sydlige og centrale Østjylland navnet Østjylland Till Formation (East Jylland Till Formation, Houmark-Nielsen 1987), mens aflejringer fra det yngre genfremstød, der afsluttede isdækket over Danmark, benævnes Bælthav Till Formation.

Typelokalitet og referenceprofil. Typelokaliteten for Lolland Till Formationen er grusgraven ved Birket på Lolland (Pedersen et al. 2015). På Møn findes et referenceprofil ved Kobbelgård (Fig. 18; Houmark-Nielsen 1994).

Lolland Till Formationen udgør sammen med Ny Borre Formationen de dominerende litologier på Møns landområde, nemlig omkring 80 \% af dæklagene. Formationen kan være vanskeligt tilgængelig på grund af sin beliggenhed øverst i de relativt høje kystprofiler.
I kystklinterne draperer formationen alle andre aflejringer og ligger i en række af kystprofilerne inkonformt over de andre glacialtektonisk forstyrrede aflejringer.

Litologi. Formationen består af siltet, brunt til gulbrunt moræneler (Fig. 19). Leret kan være massivt/kompakt, men også optræde med en svagt udviklet horisontal lagdeling. Klastindholdet er forholdsvis lavt, men der findes dog en del kalkklaster (Houmark-Nielsen 1994; Smed 2010; Gravesen et al. 2017). Lag af moræneler med meget højt indhold af kalk kan klassificeres som glacitektonit (Banham 1977, Pedersen 1988), som beskrevet i Pedersen et al. (2018). Fingrusanalyser fra en række lokaliteter (Hyde 1986; Houmark-Nielsen 1994) viser, at palæozoiske kalkkorn almindeligvis dominerer over kretasiske kalkkorn. Jordartssymboler: ML, MS.

Grœenser og tykkelse. Den nedre grænse er den glacialtektoniske inkonformitet ved formationens sål. Den hviler for det meste på Ny Borre Formationen, men i Klintholm-området på Kobbelgård Formationen (Fig. 8). Den øvre grænse er på store dele af Møn også landskabets overflade, men formationen er f.eks. ved Tøvelde Klint og Hjelm Nakke overlejret af Sen Weichselferskvandsaflejringer og stedvis af holocæne marine aflejringer, i begge tilfælde med skarpe grænser.

Generelt varierer formationens tykkelse fra 1 til 3 m, men boredata viser, at den kan være tykkere, selv om glacialtektoniske forstyrrelser kan spille en rolle. I klinterne er målt følgende tykkelser: Madses Klint: 2 m, Hvideklint: 2 m, Tøvelde klint: 2,8 m, Klintholm: 0,8 m, nordlige Møns Klint: 0,8 m, Stubberup Have: 2 m, Liselund: 1,5 m, Pomlerende; 0-2 m, Hellehavn Nakke: 2 m og Brunshoved: mindst 2 m (Hyde 1986; Gravesen et al. 2017). Tynde lag af formationen er også fundet på den hatformede bakke Præstebjerg på det sydvestlige Møn (Berthelsen 1980). Formationen findes ikke på de højeste dele af Møns Klint.

Udbredelse og korrelation. Lolland Till Formation er udbredt over hele Lolland, Falster og Møn samt på øerne i Smålandsfarvandet.

Alder. Lolland Till Formation har en alder på 18000 til 17000 år før nu (Noe-Nygaard et al. 2017).

Aflejringsmiljø. Under Nordøstisens tilbagesmeltning blev Møn, Falster, Lolland og Smålandsfarvandet efterladt som et småbakket morænelandskab. Dette moræneplateau blev efterfølgende overskredet af den Ungbaltiske Is, der fra den nordøstlige del af Østersøen spredte sig mod vest.

Analyser af klast fabrics og glacialtektonisk deformation samt et højt indhold af palæozoisk kalk viser, at moræneleret er aflejret af en gletsjer, som har bevæget sig fra sydøst mod nordvest (Hyde 1986). 


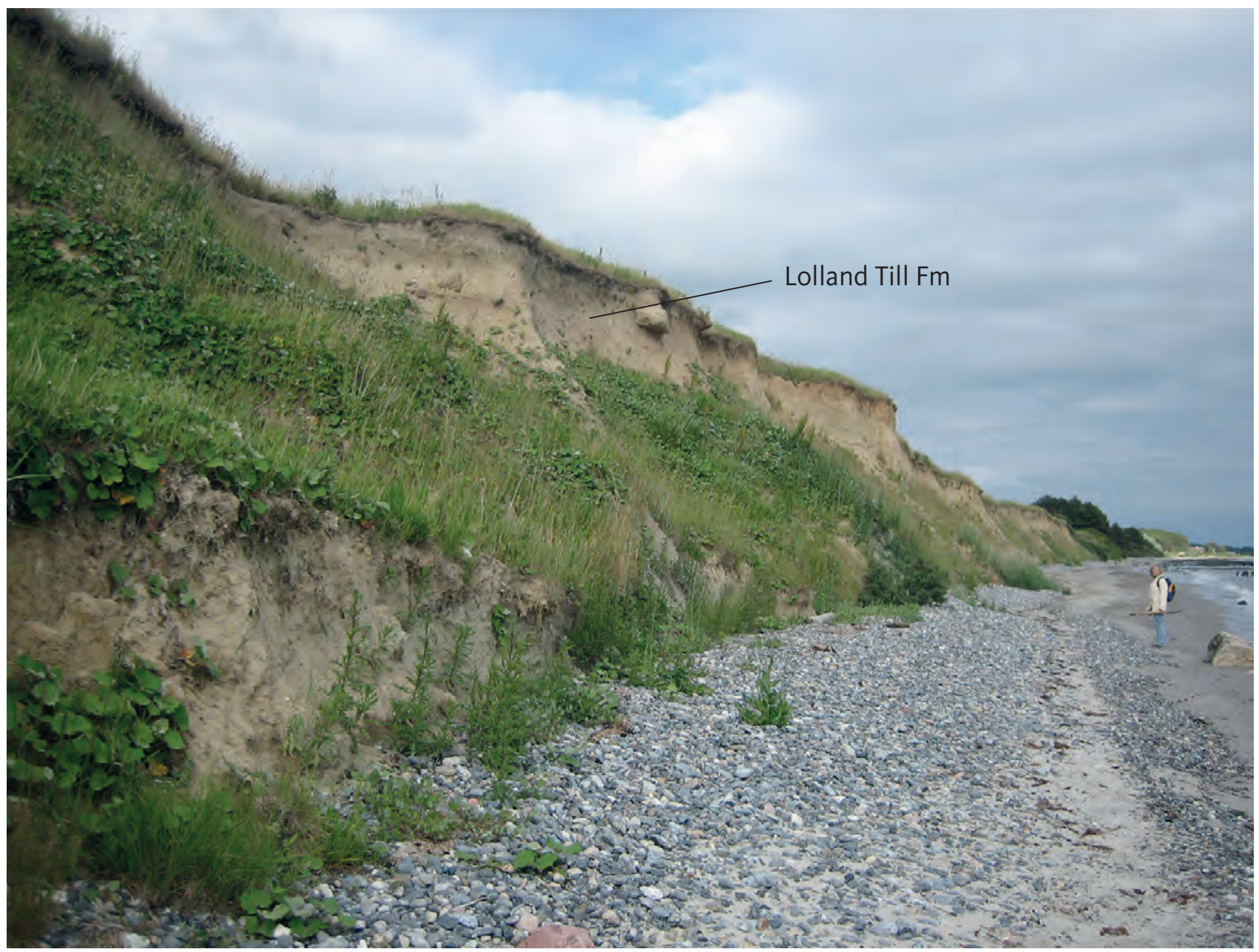

Fig. 18 Gråbrunt moræneler fra Lolland Till Formationen i klinten ved Kraneled, Klintholm.

Fig. 18. Greyish brown clayey till of the Lolland Till Formation in the uppermost part of the cliff at Kraneled, Klintholm.

Med det Ungbaltiske Isfremstød skete der under fremrykningen en spredning af den frontale del af ismassen, som resulterede $i$ en isbevægelse ud mod dens sider, dvs. isfremstød mod den centrale del af Danmark på nordsiden og mod Nordtyskland på sydsiden. På Lolland medførte dette, at den isstrøm, som først var rettet fra øst mod vest, drejede med uret og skred frem mod nordvest. I det afsluttende stadie drejede isbevægelsens retning endda op mod nordnordvest (Pedersen et al. 2015). Isfremstødet mod nordvest og nordnordvest ophørte ved den Østjyske Israndslinje i den centrale del af Djursland, hvor gletsjerens afsmeltning gav ophav til den ekstramarginale Tirstrup Hedeslette (Pedersen \& Petersen 1997). Fra denne stationære linje smeltede isen tilbage med oscillerende bevægelser. Oscillationen medførte bl.a. Bælthav Isfremstødene, hvor en serie lokale israndslinjer er kortlagt (Milthers 1948). På Møn gav dette fremstød kun ophav til en aflejring af moræneler, mens den på dele af Lolland og Falster gav ophav til opsplitningen af Lolland Till Formationen i to enheder af moræneler adskilt af et tyndt lag smeltevandssand.

\section{Sen Weichsel (Senglacial, MIS 2)}

Aflejringer fra den sidste del af Sen Weichsel (Senglacial) kendes især fra to lokaliteter på Møns sydkyst: Hjelm og Tøvelde, hvor ferskvandslagene omfatter store dele af det senglaciale tidsafsnit: Ælldste Dryas, Bølling, Ældre Dryas, Allerød og Yngre Dryas (Kolstrup 1982; NoeNygaard \& Heiberg 2001). Aflejringerne er dannet mellem 17000 og 11700 år før nu. Tøvelde er en af de bedst undersøgte senglaciale lokaliteter med et næsten helt komplet senglacialt profil (Fig. 20).

Senglaciale ferskvandslag er også fundet i moser på Høje Møn (Hintze 1937), mens der ikke er tegn på marine aflejringer af denne alder på Møn. Ved Madses Klint findes lag af kalkgytje og tørv på toppen af den ungbaltiske Lolland Till Formation. Lagene er ikke dateret, men kan være senglaciale eller postglaciale (Fig. 21). Endelig træffes senglaciale aflejringer $\mathrm{i}$ bunden af Borre Sømose profilet (Mikkelsen 1949). Ferskvandssedimenterne består overvejende af ferskvandsler (TL), ferskvandssilt (TI), ferskvandsgytje (TP), ferskvandstørv (TT), vekslende lag (TV), ferskvandssand (TS) og ferskvandsgrus (TG). 


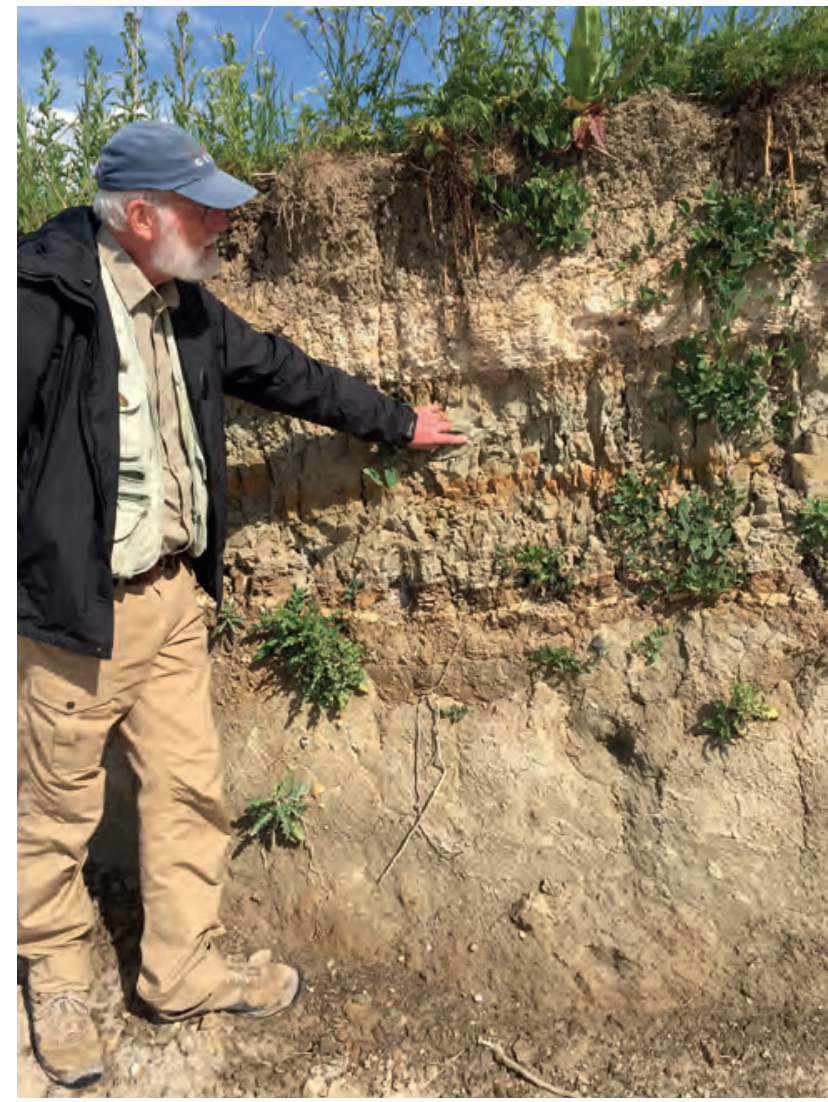

Fig. 19 Gråbrunt moræneler tilhørende Lolland Till Formationen under Sen Weichsel lakustrine aflejringer ved Tøvelde Klint. Ved toppen af de lakustrine sedimenter ses en kalkgytje.

Fig. 19. Grey-brown, clayey till of the Lolland Till Formation below Late Weichselian freshwater deposits at Tøvelde Klint. At the top of the lacustrine succession a calcareous gyttja is seen.

Tøvelde-lokaliteten er velblottet over ca. $100 \mathrm{~m} \mathrm{i}$ kystklinten ved Tøveldestenen og er sammensat af flere små søbassiner, som har udviklet sig til en sø gennem tid. Hjelm-lokaliteten har en mere begrænset udstrækning, og den ligger højt i kystprofilet og er vanskeligt tilgængelig (Heiberg 1991). De to velbeskrevne lokaliteter viser søbassiner med en omfattende ferskvandsfauna og -flora samt også terrestriske dyr, der har levet omkring søerne (Johansen 1904; Heiberg og Bennike 1997; Noe-Nygaard \& Heiberg 2001). Faunaen omfatter bl.a. terrestriske pattedyr (gnavere), padder, snegle, muslinger, insekter og planter, samt ferskvandsfisk, snegle, muslinger, insekter og planter. Den samlede tykkelse er på op til 3,8 m.

På Høje Møn er aflejringer i flere moser blevet undersøgt (Hintze 1926, K. Jessen i Hintze 1937), og i nogle af dem er der fundet en Sen Weichsel-ferskvandslagfølge af ler fra ÆEldre Dryas, gytje fra Allerød og ler fra Yngre Dryas, overlejret af lag fra Holocæn.

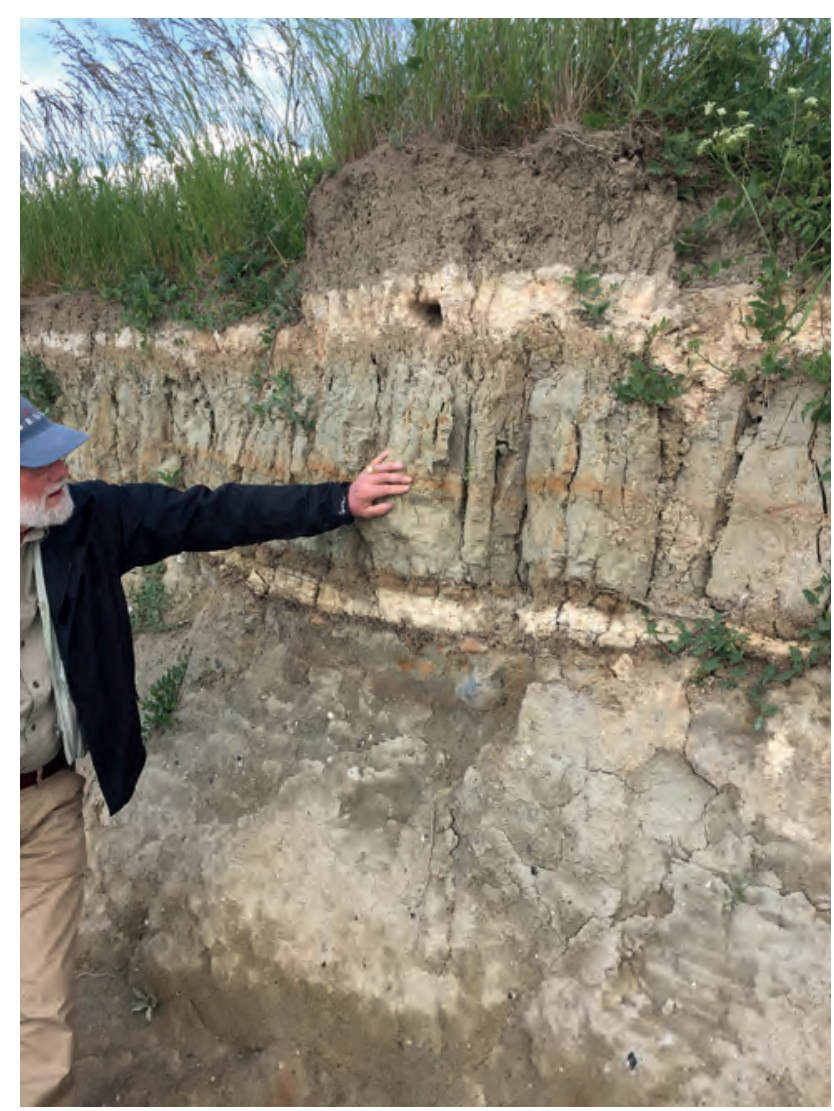

Fig. 20 Sen Weichsel - holocæne aflejringer i et søbassin ved Tøvelde, som ligger i en lavning i moræneler fra det Ungbaltiske Isfremstød.

Fig. 20 Late Weichselian - Holocene lacustrine deposits at Tøvelde, formed in a shallow depression of the till of the Young Baltic Ice Advance.

\section{Udviklingen i Sen Weichsel (Senglacial)}

I Sen Weichsel blev en stor isdæmmet smeltevandssø, den Baltiske Issø, etableret i den sydlige del af Østersøen for omkring 16000 år siden. I de mindre sølavninger på Møn ved Hjelm og Tøvelde blev der med lidt varierende udvikling dannet forskellige sedimenter, især tørv og gytje. Søbassinerne blev dannet $i$ et højtliggende landskabsparti og opstod ved smeltning af dødis efterladt fra afsmeltningen af den Ungbaltiske Is. De klimatiske forhold havde stor betydning for aflejringen i de relativt lavvandede søer, men også niveauændringer i den Baltiske Issø spillede en rolle for søernes udvikling (Kolstrup 1982; Noe-Nygaard \& Heiberg 2001; NoeNygard et al. 2017; Rosentau et al. 2017).

I Ældste Dryas indvandrede en lav tundravegetation til et landskab uden planter. I de fladbundede lavninger ved Hjelm og Tøvelde blev der aflejret sand, silt og resedimenteret moræneler med plantemateriale, som blev skyllet ud eller gled ud som flydejord fra det omgivende landskab. Plantematerialet bestod bl.a. af dværgpil, bynke, græsser og halvgræsser.

I Bølling tid blev det varmere, og planter som havtorn 


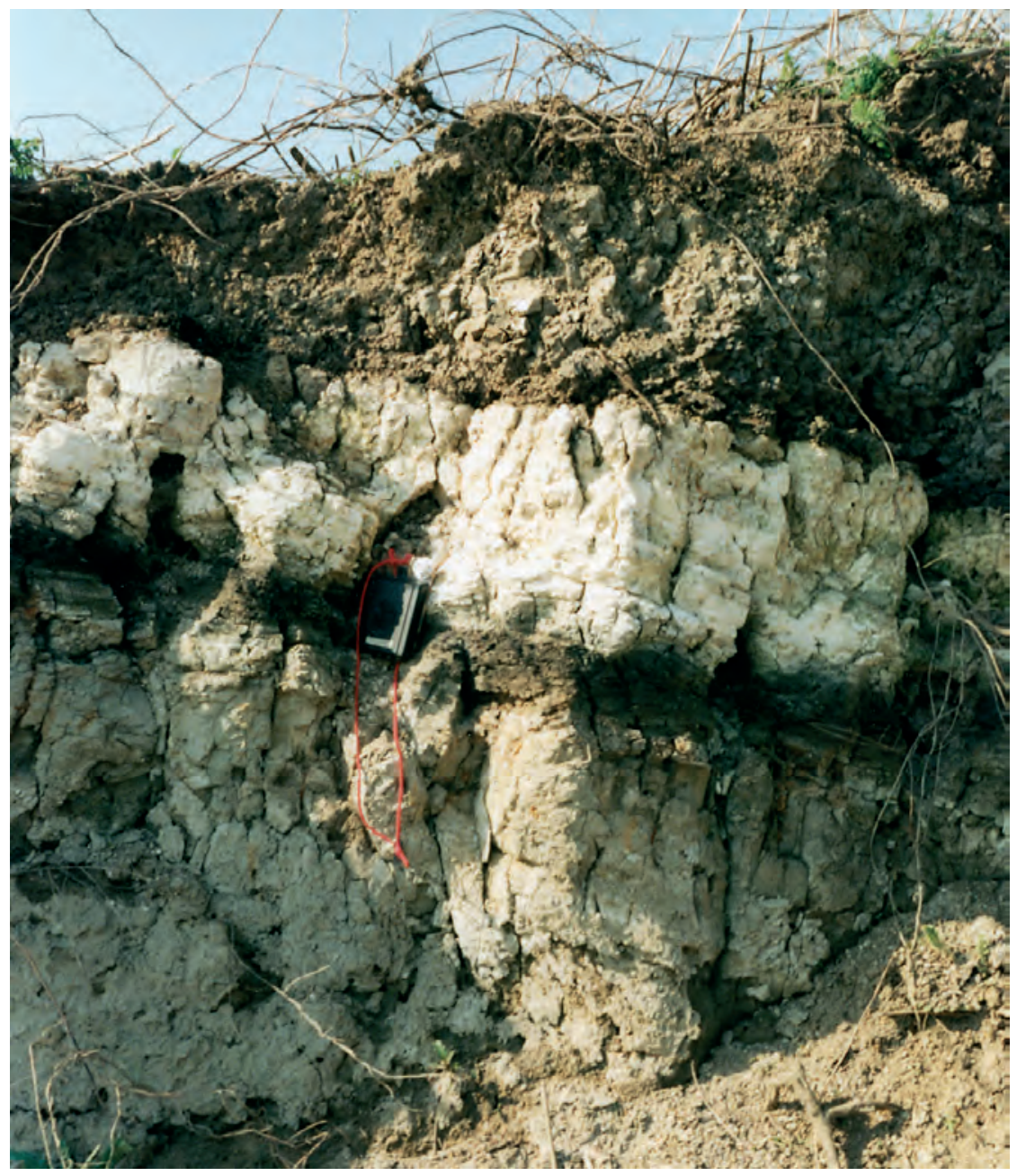

Fig. 21 Sen Weichsel ferskvandsaflejringer højt oppe i klinten ved Madses Klint, som indeholder en ca. $20 \mathrm{~cm}$ tyk kalkgytje. Foto: Tove Stockmarr.

Fig. 21: The Late Weichselian freshwater deposits high up in the section at Madses Klint, which contains a bed of $20 \mathrm{~cm}$ thick calcareous gyttja. Photo: Tove Stockmarr.

og dværgbirk indvandrede sammen med pil, Dryas og padderokke. Det højere planteindhold betød et højere humusindhold i jordbunden, og øget nedbør førte til udvaskning af kalk fra det kalkholdige moræneler og -sand ud i de lavvandede søer, som var etableret. Fiskefossiler er truffet i søerne, og landsnegle levede omkring dem. Humusholdigt sand blev aflejret i et sumpet sømiljø i den sidste del af Bølling.

I Ældre Dryas blev klimaet mere tørt og koldt, og mængden af dværgbirk faldt markant. Kalkholdigt ler med dropsten blev aflejret i søbassinerne, og der blev skyllet usorteret jordmateriale ud i bassinerne, hvor kalkudvaskningen stoppede.

I Allerød blev det betydeligt varmere end i de tidligere tidsafsnit, selv om to korte kuldeperioder indtraf. Almindelig birk indvandrede. Gytjelag og tørv blev dannet i de fladvandede søer ved tidsafsnittets begyndelse. Udvaskningen fra de kalkholdige lag af moræneler blev forøget, og det højere kalkindhold i søvandet bevirkede, at de lakustrine sedimenter blev præget af kalkgytje overvejende bestående af kransnålalger (characékalk). Disse alger kan optage $\mathrm{Ca}^{2+}$-ioner fra søvandet og udfælde søkalk. Vandspejlet i søerne varierede gennem tidsafsnittet, men mod slutningen faldt det med sumpdannelse til følge, og der blev igen aflejret alge- og detritusgytje (Fig. 20). I og omkring søerne fandtes en artsrig flora og fauna.

I det sidste Sen Weichsel-tidsafsnit, Yngre Dryas, blev det igen koldere, og aflejringerne blev mere sandede med laminerede silt- og lerlag uden characékalk, men med dropsten og talrige planterester. Søernes vandniveau var stigende gennem tidsafsnittet. Sedimentationen markerer opfyldningen af søerne med materiale fra det omgivende træløse landskab. Ved år 11700 før nu blev Sen Weichsel afløst af det generelt varmere klima i Holocæn.

Under den Baltiske Issøs forskellige faser fra Weichsel til Holocæn gennemgik farvandene omkring Møn, Fakse Bugt og Hjelm Bugt markante niveauændringer. Der blev dannet lagune-, ferskvands- og kystaflejringer samt sø- og moseaflejringer gennem Sen Weichsel (Jensen 1993; Bennike \& Jensen 1995; Jensen et al. 1997).

\section{Holocæne aflejringer (Postglacial, MIS 1)}

Det holocæne tidsafsnit (Postglacial) siden 11700 år før nu er opdelt i tidsafsnittene Præboreal, Boreal, Atlantisk, Subboreal og Subatlantisk tid (nutid). Disse enheder er bestemt på få lokaliteter, hvor profilerne ofte består af både ferskvands- og marine aflejringer. Det mest 
komplette profil findes i Borre Sømose lavningen (Fig. 22; Mikkelsen 1949), mens dele af de holocæne aflejringer er undersøgt i forbindelse med de senglaciale profiler ved Tøvelde (Noe-Nyegaard \& Heiberg 2001).

\section{Ferskvandsaflejringer}

De holocæne ferskvandsaflejringer består af fem forskellige sedimenttyper: tørv (FT), gytje (FP), ler (FL), sand (FS) og heterolitiske (FV) aflejringer. I alt dækker ferskvandsaflejringerne ca. $7 \%$ af landarealet. Ferskvandsaflejringerne af Holocæn alder består af to hovedgrupper: 1) på toppen af og mellem de marine postglaciale aflejringer og 2) i de isolerede lavninger (moser og søer) i det kuperede morænelandskab, ofte på senglaciale lag.

På Fig. 22 ses, hvordan de postglaciale lag overlejrer de senglaciale aflejringer i Borre Sømose, hvor en næsten kontinuerlig lagfølge er aflejret fra Præboreal til Subatlantikum. Det geologiske kort viser et stort antal isolerede forekomster af tørv, der er dannet i de dødishuller, som opstod ved slutningen af senglacialtiden, da resten af den sidste smeltende gletsjer forsvandt. Andre spredte ferskvandsaflejringer opstod i flade lavninger på morænefladen og i det småbakkede morænelandskab. Større søer som Røddinge, Råby og Råbylille søer groede til i Holocæn, og der blev dannet tørv som i Busemarke Mose. Det største ferskvandsbassin er Borre Sømose, som behandles nærmere i afsnittet om den holocæne udvikling. På Høje Møn er der i moser over de senglaciale lag fundet aflejringer fra Holocæn startende med Boreal (Hintze 1926, Jessen i Hintze1937).

Ferskvandsaflejringerne domineres som nævnt af tørv. Undersøgelser af tørven viser en vegetationsudvikling gennem Præboreal, Boreal, Atlantisk, Subboreal og Subatlantisk tid, som svarer til den øvrige del af det centrale og sydlige Danmark (Noe-Nygaard et al. 2017). Store dele af et bjørneskelet er fundet i Kam Mose. Bjørnen formodes at have levet i den tidlige del af Holocæn (Jessen 1929).

\section{Marine aflejringer}

De holocæne marine aflejringer udgør ca. $10 \%$ af jordarterne på land og opdeles i gytje og organisk mudder (HP), ler (HL), sand (HS) samt grus og sten i strandvolde (HG). Havaflejringer træffes mange steder langs kysterne med strandvolde som den dominerende del. Strandvoldene danner vinkelforland og krumoddesystemer på øens fremskudte kyster og pynter, som ved f.eks. Hårbøllebro. Ulvshale er en stor strandvoldsslette, hvor der under de grovkornede strandvolde ligger omkring 7,5 m marint sand med postglaciale skaller og højt indhold af organisk materiale. Nyord er formodentlig dannet som et tilgroningsforland beskyttet af den tilknyttede knold af $20 \mathrm{~m}$ tykt moræneler (Fig. 23). Knolden er antagelig dannet af glacialtektonisk opskudte flager af moræneler. På mange grovkornede forstrande og strandvolde dominerer flint, som stammer fra skrivekridtklinterne. På stranden for foden af Møns Klint kan træffes flere generationer af strandvolde (Fig. 24). Strandvolde kendes også fra nordkysten af Møn og ud mod Gyldenløves Flak (Andersen 1936). Tykke havaflejringer er dannet under havstigningerne i Atlantisk tid (Littorinahavet). De er især fundet i Borre lavningen i form af cardiumgytje (efter muslingen Cardium edule; Mikkelsen 1949). Den hævede havbund fra Littorinahavet, som ligger i kote 0 eller -1, er afgrænset fra det nuværende hav med diger og kan udgøre store, næsten vandrette flader, som ved Kostervig, hvor fladen er opdyrket.

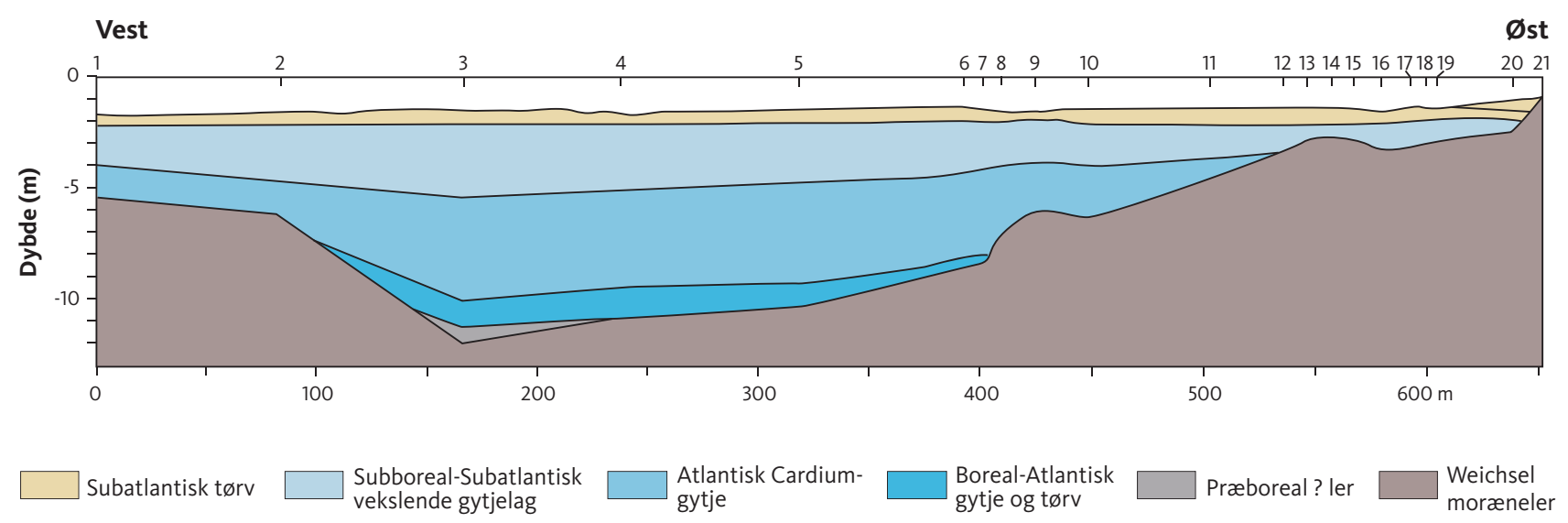

Fig. 22 Fig. 22. Profil gennem Borre Sømose, der viser udviklingen fra den allersidste del af Sen Weichsel til den sidste del af Holocæn. Tallene 1-21 angiver placeringer af korte boringer. Fra Gravesen et al. (2017), modificeret fra Mikkelsen (1949).

Fig. 22. Section through Borre Sømose showing the development from the late Late Weichselian towards the last part of the Holocene. The numbers 1-21 show the positions of shallow boreholes. From Gravesen et al. (2017), modified from Mikkelsen (1949). 


\section{Klitdannelser}

Nutidige flyvesandsdannelser (ES) i form af kystklitter findes på nordøstkysten af Ulvshale, langs kysten ved Klintholm Havn og ved Råbylille i Hjelm Bugt. Der findes også ganske få områder med flyvesand oven på ferskvandsaflejringer.

\section{Udviklingen gennem Holocæn}

I Præboreal i den første del af Holocæn steg temperaturen hurtigt. Herefter fulgte en kort kuldeperiode, inden det igen blev varmere og tørt. Græs og urter vandrede ind. I den fladvandede $s \varnothing$ ved Tøvelde blev der først aflejret algegytje med højt organisk indhold, og efter en stigning af vandspejlet blev der aflejret characékalkgytje (Mikkelsen 1949; Noe-Nygaard \& Heiberg 2001). I den kolde periode blev ler skyllet ud over gytjelagene, og nye gytjelag blev aflejret igen, da det blev varmere. Nu indvandrede bl.a. birk, fyr og asp og senere bøg, eg, elm og hassel.

I Borre Sø lavningen, der blev dannet som en U-formet smeltevandskanal ved smeltningen af den Ungbaltiske

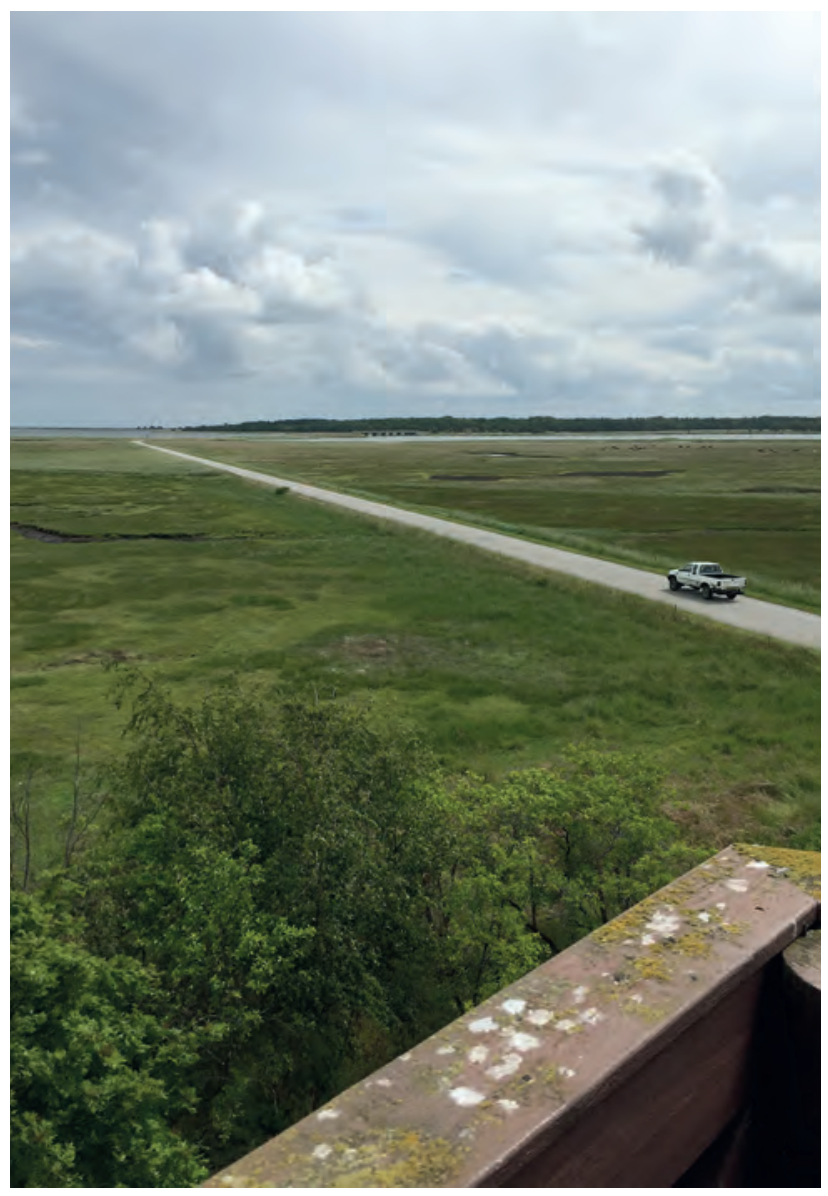

Fig. 23 Holocæn strandvoldsslette ved Nyord-Ulfshale set mod øst.

Fig. 23. Holocene plain of beach ridges at Nyord-Ulfshale. View towards east.
Is, fandtes en fladvandet sø ved overgangen til Holocæn (Fig. 22). I Præboreal og Boreal tid blev der dannet en mose med trævækst.

I Præboreal var Danmark landfast med Sydsverige og Sydengland. Denne situation fortsatte et stykke ind i Boreal tid og kaldes samlet Fastlandstiden. Den Baltiske issø eksisterede stadig ved starten af Præboreal, men den blev tappet 10300 år før nu.

I Boreal tid voksede planter ud over Tøvelde søerne, eller træer væltede ned i dem, og der blev dannet tørv, heraf en del tykke lag af sumptørv med tusinder af skaller af ferskvandssnegle og -muslinger. Søerne blev efterfølgende omdannet til lavmoser. I dette tidsafsnit blev det baltiske område igen til en stor ferskvandss $\varnothing$, Ancylussøen, der mindede om den Baltiske Issø, der havde eksisteret få tusind år forinden.

Derefter, i Atlantisk tid, blev store dele af Danmark overskyllet af Littorinahavet. På Møn blev lavtliggende områder langs kysten og gamle fjorde som Borre Sømose en del af dette hav (Fig. 22; Krog 1979). Der blev aflejret tykke marine lag af cardiumgytje, og aflejringen fortsatte op gennem Atlantisk og videre ind i Subboreal tid. Fra disse tidsafsnit kendes en omfattende flora og fauna.

I Subatlantisk tid var der afvekslende lakustrine forhold og marine fjorde, og aflejringerne ændredes i takt hermed mellem ferskvandsgytje og kalkgytje. De skiftende aflejringsforhold var også et resultat af tilstedeværelsen af tærskler og barrierer, som stedvist blev dannet foran fjordene som f.eks. i Borre Sømose i takt med, at havniveauet ændrede sig. Til sidst blev der mange steder dannet søer, som voksede til, dannede tørv og blev til moser.

De recente marine aflejringer består mest af sand, grus og sten. Ikke mindst strandvoldene er domineret af grus og sten. Havbunden og de underliggende lag omkring Møn er kortlagt i forbindelse med råstofundersøgelser efter sand, grus og stenressourcer (Fredningsstyrelsen 1977, 1986) i henholdsvis Hjelm Bugt og Fakse Bugt og sammenstillet af Jensen (1993). I farvandet mellem Falster og Møn findes Grønsunds tragtformede munding med en central rende omgivet af flak og barrer dannet af stormskabte strømme (Fredningsstyrelsen 1977). Den yngste nutidige aflejring er flyvesand, som har dannet klitter, især langs kysterne.

\section{Lagenes optræden og strukturelle forhold}

Skrivekridtets beliggenhed og fordelingen af skrivekridtlag overlejret af kvartære enheder, samt opbygningen af den kvartære lagserie og den strukturelle fordeling af de forskellige formationer er dokumenteret i fire tværsnit A-B, C-D, E-F og G-H gennem landskabet 


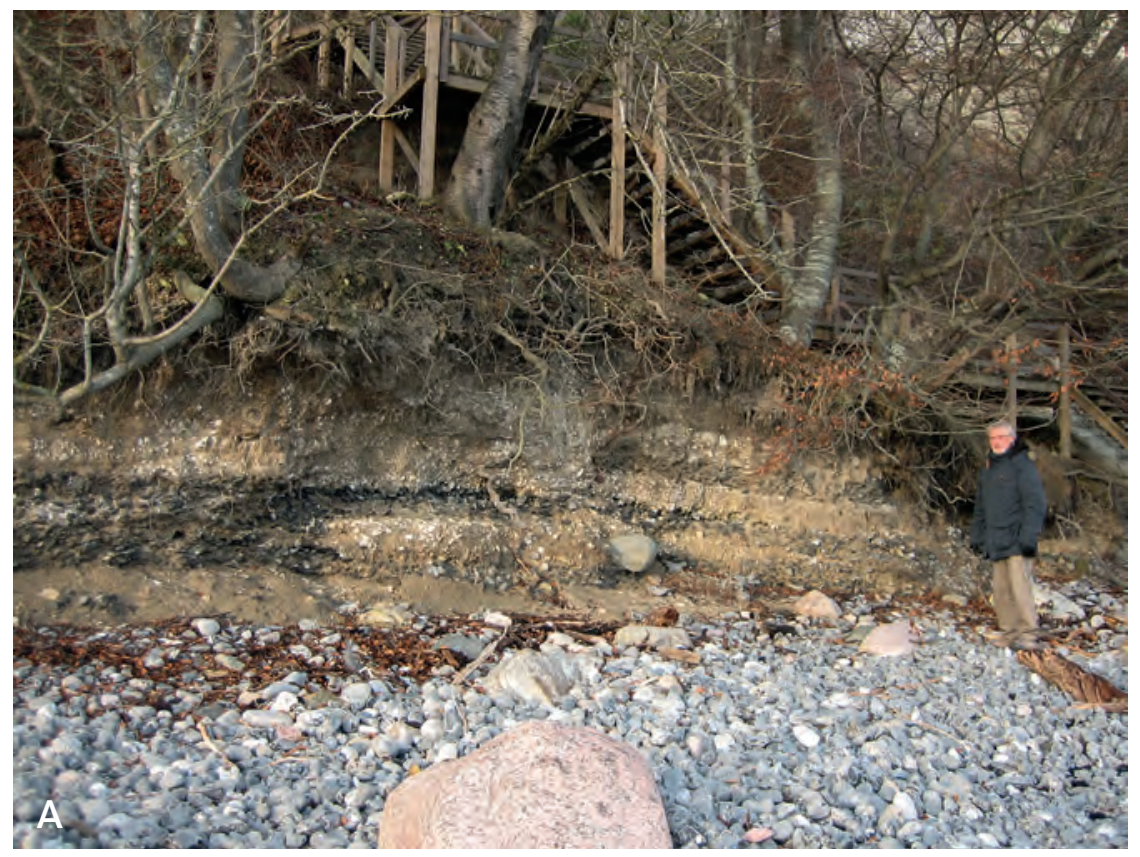

Fig. 24 Generationer af holocæne strandvolde ved Gråryg, Møns Klint. A: Overblik over lokaliteten med recente strandaflejringer i forgrunden. B: Detaljer af de ældste strandvolde.

Fig. 24. Generations of Holocene beach ridges at Gråryg close to Møns Klint. A Overview of the locality with recent beach deposits. B: Details of the oldest beach ridges.

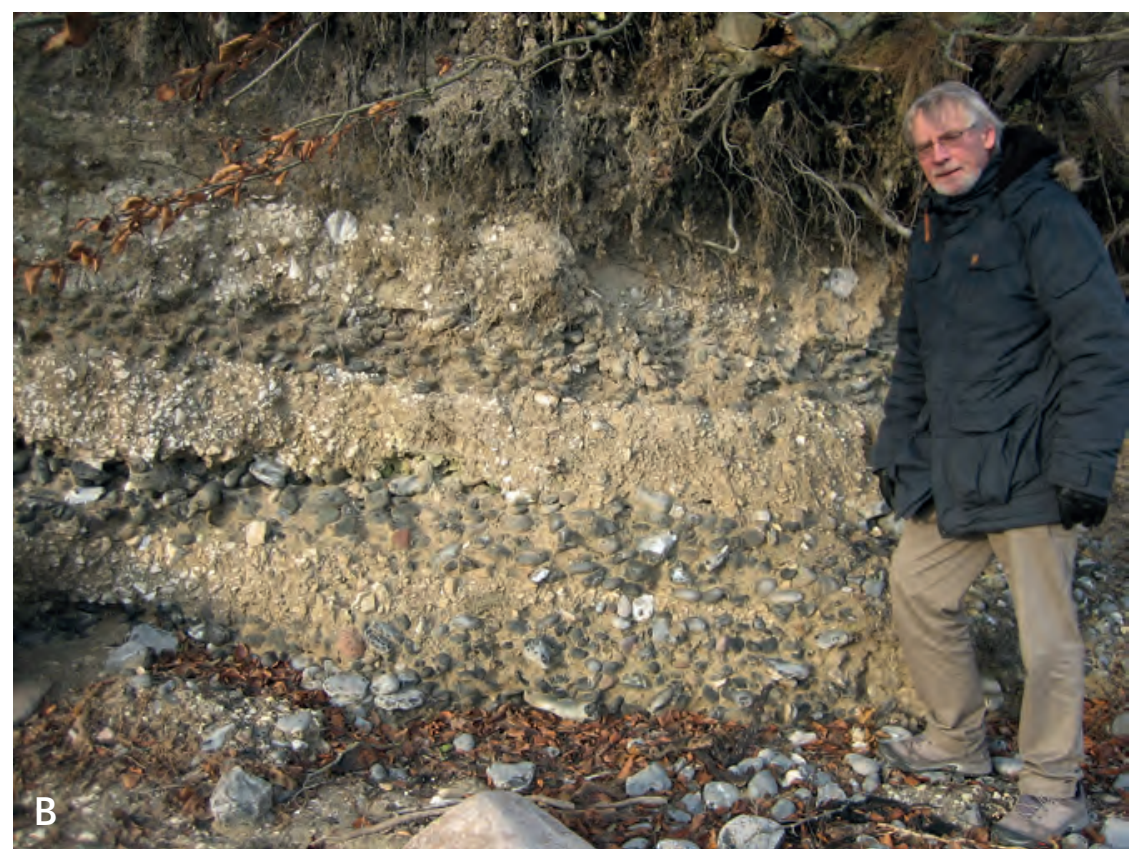

på Møn. Disse indgår på kortbladet Møn. Desuden er to kystprofiler, henholdsvis Møns Klint (historisk) og Hvideklint, medtaget i beskrivelsen. Konstruktionen af tværsnittene er baseret på boringer inden for kortbladet, som findes i GEUS' boredatabase Jupiter (Gravesen \& Fredericia 1984) samt oplysninger fra grundvandskortlægning (Rambøll 2006, 2007), råstofgrave (Region Sjælland 2012) og klintprofilerne. Den vestlige del af tværsnit G-H er vist her som et særskilt tværsnit med de nye formelle stratigrafiske enheder anført på de enkelte lag (Fig. 25). På profilerne fra kystblotningerne er der foretaget en strukturel tolkning af lagseriernes forløb i dybet.
Tværsnittene baseret på boringer repræsenterer et overblik over undergrundens opbygning fra toppen af skrivekridtet til terrænoverfladen på den indre del af Møn (Fig. 26). Møns Klint vises i Fig. 27 i en bearbejdet udgave af det klassiske profil udarbejdet af Puggard (1851). Profilet langs Hvideklint er baseret på en nyopmåling understøttet af opmålingen af Stockmarr (1996). Det er dog kun de østligste $800 \mathrm{~m}$ af kystklinten fra Hvideklint til Hjelm Nakke, som indgår i profilet (Fig. 28). 


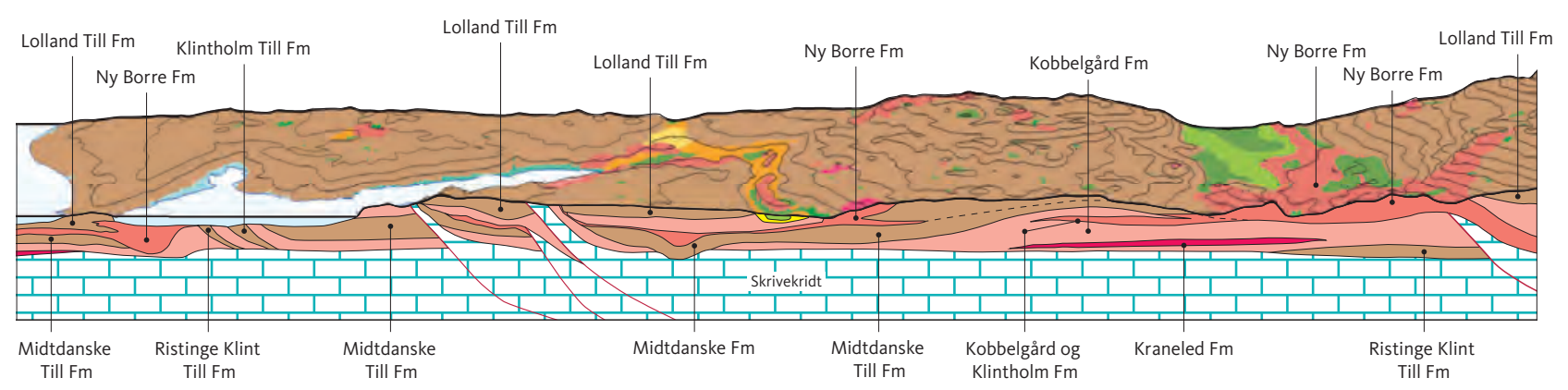

Fig. 25 Geologisk tværprofil G-H med formationsnavne for de kvartære aflejringer (sammenlign med tilsvarende profil og signaturforklaring på kortbladet). Dette og de øvrige profiler vist på kortbladet er konstrueret og tolket ved hjælp af boredata fra kortbladsområdet. De kvartære aflejringer domineres af smeltevandssand og grus (rød), smeltevandsler og silt (orange) og moræneler (brun). Tværprofilet løber øst-vest gennem midten af Møn mellem Stege og Høje Møn.

Fig. 25. Geological profile $\mathrm{G}-\mathrm{H}$, annotated with formation names and other geological units (compare with the corresponding profiles and legend on the map sheet). This and the other profiles shown on the map sheet have been constructed and interpreted based on well data from the map sheet area. Meltwater sand and gravel (red), meltwater clay and silt (orange) and clayey tills (brown) dominate the Quaternary deposits. The profile is orientated E-W through the central part of Møn from Stege to Høje Møn.

\section{De geologiske tværsnit baseret på boringer og andre kortlægninger}

\section{Tvoersnit $A-B$}

Tværsnit A-B (orienteret NV-S $\varnothing$ ) går på tværs af det vestlige Møn, fra Hvideklint mod nordvest over Nørre Frenderup til Koster Vig, over Koster halvøen til Ulvsund og videre til Gammel Kalvehave på Sjælland.

Det småbakkede morænelandskab ved Gammel Kalvehave og Koster Land er omkranset af et holocænt marint forland. Ved Damsholte krydser tværsnit A-B en dal, som løber sydvest-nordøst. Dalen er fyldt med smeltevandsler, -sand og -grus afsat af Hovedfremstødet. Den tolkes som en tunneldal (Rasmussen 1965; Smed 2014). Dette dalforløb kan følges mod nordøst ud gennem Stege Nor, men som det fremgår af tværsnit A-B, er dalens forløb delvis modificeret af det Baltiske Isfremstød. Stege Nor og bakkerne i landskabet sydøst herfor danner et sammensat parallelt dal- og bakkestrøg, som skyldes isfremstødet fra sydøst af den Ungbaltiske Is. I den sydøstligste del af tværsnit A-B findes gendeformerede, opskudte skiver af skrivekridt i Hvideklint. Skrivekridtoverfladen, som ikke er påvirket af glacialtektonisk oppresning, ligger nogenlunde horisontalt mellem kote $-20 \mathrm{~m}$ og $-30 \mathrm{~m}$ (Fig. 2), hvilket i tværsnit A-B dog kun er tilfældet ved Æbelnæs sydøst for Kostervig.

\section{Tvoersnit $C-D$}

Tværsnittet C-D, som er orienteret N-S, starter i Hjelm Bugt ved Råbylille Sø og går nordpå tværs over den østlige del af Møn, op over højdedraget ved Elmelunde og videre til nordkysten ved Nordfelt vest for Borre Sømose. Det bakkede morænelandskab udgøres af Lolland Till Formationen fra det Ungbaltiske Isfremstød, men omkring det højtliggende Elmelunde, som er presset op af glacialtektoniske skrivekridtskiver, træder smeltevandssand og grus fra Ny Borre Formationen frem i terræn. De to formationer kan følges gennem hele profilet. Mod syd træffes holocæne ferskvandsaflejringer i den $\varnothing$-V-orienterede Råbylille Sø. Den ligger i en fordybning i morænelandskabet, der kan tolkes som en del af Råbylille tunneldalen. Søen er groet til, og der er dannet tørv. Langs kysten træffes nutidigt flyvesand. Den upåvirkede skrivekridtoverflade ligger nogenlunde horisontalt i kote -30 til $-40 \mathrm{~m}$.

\section{Tvoersnit E-F}

Tværsnittet E-F, orienteret SV-NØ, går fra Stege over Damsholte, Røddinge Sø og Store Damme til Fanefjord. Steges morænelandskab består af mindre aflange bakker orienteret SV-NØ, som ligger på skiver af opskudt skrivekridt. I hele profilets længde følges en dalstruktur, som har fungeret som dræningskanal for $\mathrm{N} \emptyset$-Isens smeltevand. Dele af dalen er tolket som en tunneldal med mindre åse, bl.a. Fanefjord Ås og hatformede bakker (Rasmussen 1965; Smed 2014). Hele systemet har senere fungeret som dræningskanal for den Ungbaltiske Is bl.a. gennem Røddinge Sø kanalen, og Ny Borre Formationen blev aflejret. Røddinge lavningen er nu tilgroet, og der er dannet tørv. Fanefjord omkranses af holocænt marint sand, og ved østersøkysten findes grovkornede strandvolde.

Ved en kabelnedgravning nær transformatorstationen i den østlige udkant af Neble blev skiver af skrivekridt blotlagt i sommeren 2015 (Fig. 26). Det viser, at de skrivekridtskiver, der er antydet i den østlige tredjedel af tværsnit E-F, nok er underdrevet i profilkonstruktionen, som er udført 10 år tidligere. Som det ses i Fig. 26, når skrivekridtet helt op til overfladen. Vest for landsbyen Neble er skrivekridtoverfladen så godt som upåvirket af glacialtektonik. Den prækvartære overflade ligger nogenlunde horisontalt i en dybde omkring kote -25 til $-30 \mathrm{~m}$. 


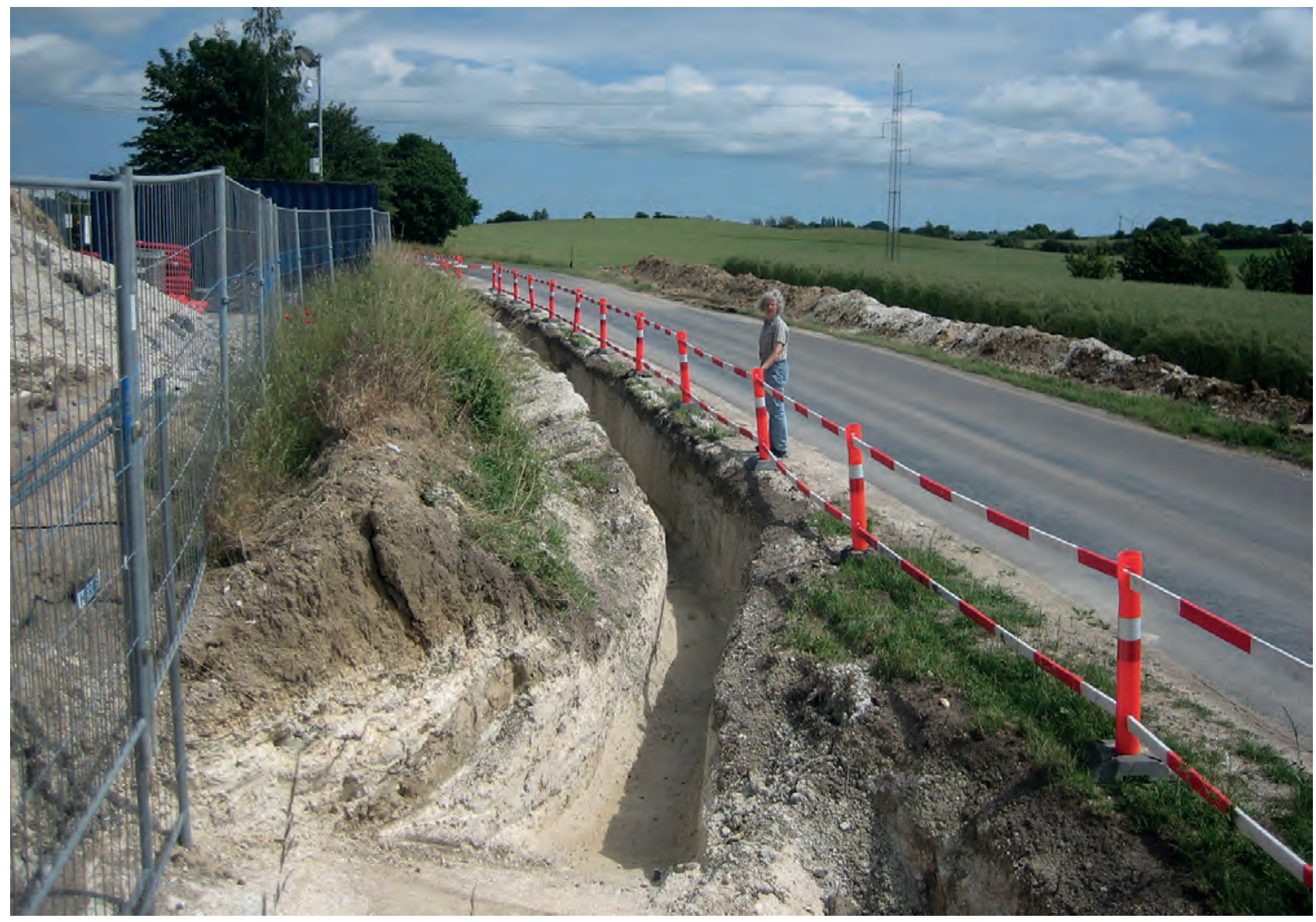

Fig. 26 Højtliggende skrivekridtskiver blottet i en udgravning ved transformatorstationen i Neble.

Fig. 26. Elevated chalk sheets exposed in an excavation at the transformer station in Neble.

\section{Tvoersnit G-H}

På langs af den centrale del af Møn findes det længste tværsnit G-H (orienteret $\mathrm{V}-\varnothing$ ), som løber fra Stege over Råbylille, Råbymagle, Borre Sømose, Busemarke, Store Klinteskov til Møns Klint ved Store Klint og Dronningestolen. Et udsnit af dette tværprofil er vist på Fig. 25, hvor Høje Møn er udeladt. De litostratigrafiske enheder, som er opstillet i denne publikation, er markeret på Fig. 25.

Mod øst i Høje Møn-området er de store skrivekridtskiver presset op til $125 \mathrm{~m}$ o.h., og der ligger et tyndt dække af glaciale, interglaciale, senglaciale og postglaciale aflejringer over skiverne. Det høje terræn afløses af den markante fordybning med Borre Sømose, som er fyldt op af senglaciale og postglaciale aflejringer. Borre Sømose fordybningen er desuden fyldt med aflejringer af sand og grus tilhørende Ny Borre Formationen og har fungeret som dræningskanal for den Ungbaltiske Is. Området syd for Elmelunde er et højere beliggende småbakket morænelandskab. I Stege Nor omkranser holocæne marine sandaflejringer havbugten.

På en del af profilet i Fig. 25 ses, hvordan de litostratigrafiske enheder antages at ligge $i$ forhold til hinanden inde på Møn, altså væk fra kystprofilerne, som de ikke direkte kan sammenlignes med på grund af det forskellige datagrundlag. Tværprofilet viser følgende formationer: Ristinge Till, Kraneled, Klintholm Till, Kobbelgård, Midtdanske Till, Ny Borre og Lolland Till Formationerne. Vest for Høje Møn ligger det meste af skrivekridtoverfladen nogenlunde horisontalt i kote -30 til $-40 \mathrm{~m}$, men kan stedvis nå op til $-20 \mathrm{~m}$. Under Høje Møns skrivekridtskiver mod øst forventes den faststående skrivekridtoverflade at ligge under kote $-100 \mathrm{~m}$. Isolerede skrivekridtlegemer af forskellige størrelser er indlejret i de kvartære aflejringer (se også Houmark-Nielsen 2003).

\section{Skrivekridtprofiler i kystklinter}

\section{Møns Klint}

Møns Klint er et imponerende kystprofil, som giver et nord-sydgående erosionssnit gennem det østlige Møns stærkt kuperede og efter danske forhold høje, stejle landskab, det såkaldte Høje Møn. I mere end 150 år har det været velkendt, at klintens morfologi skyldes dens opbygning af skrivekridtflager, som er stablet oven på hinanden (Puggaard 1851; Schou 1949; Pedersen 2000). Den strukturelle dannelse blev allerede for mere end 

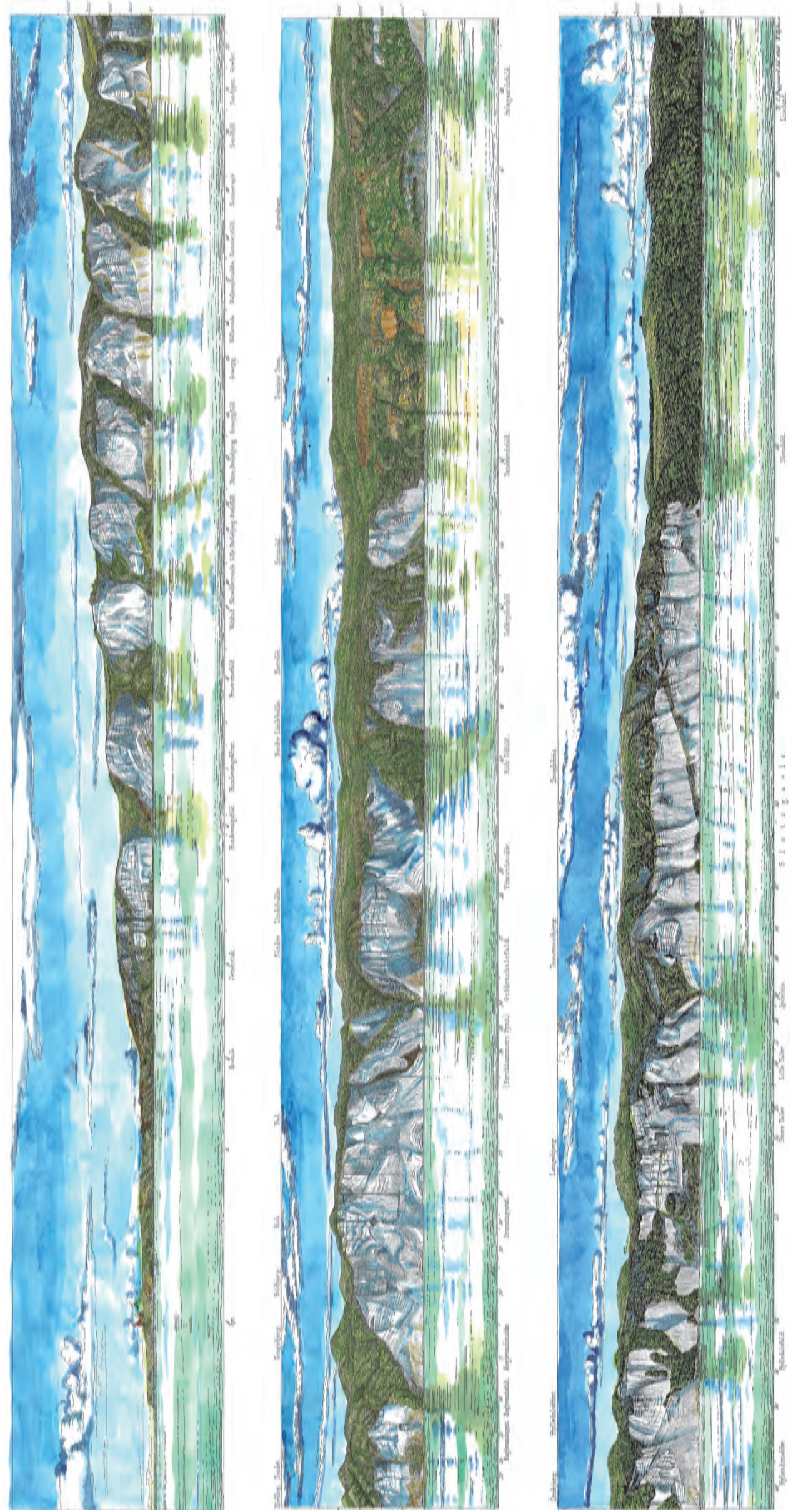

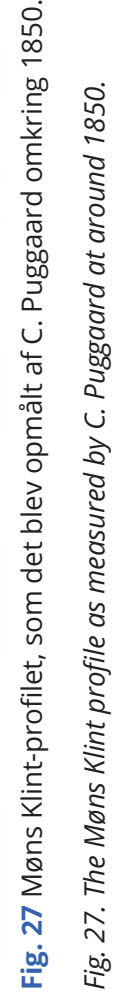



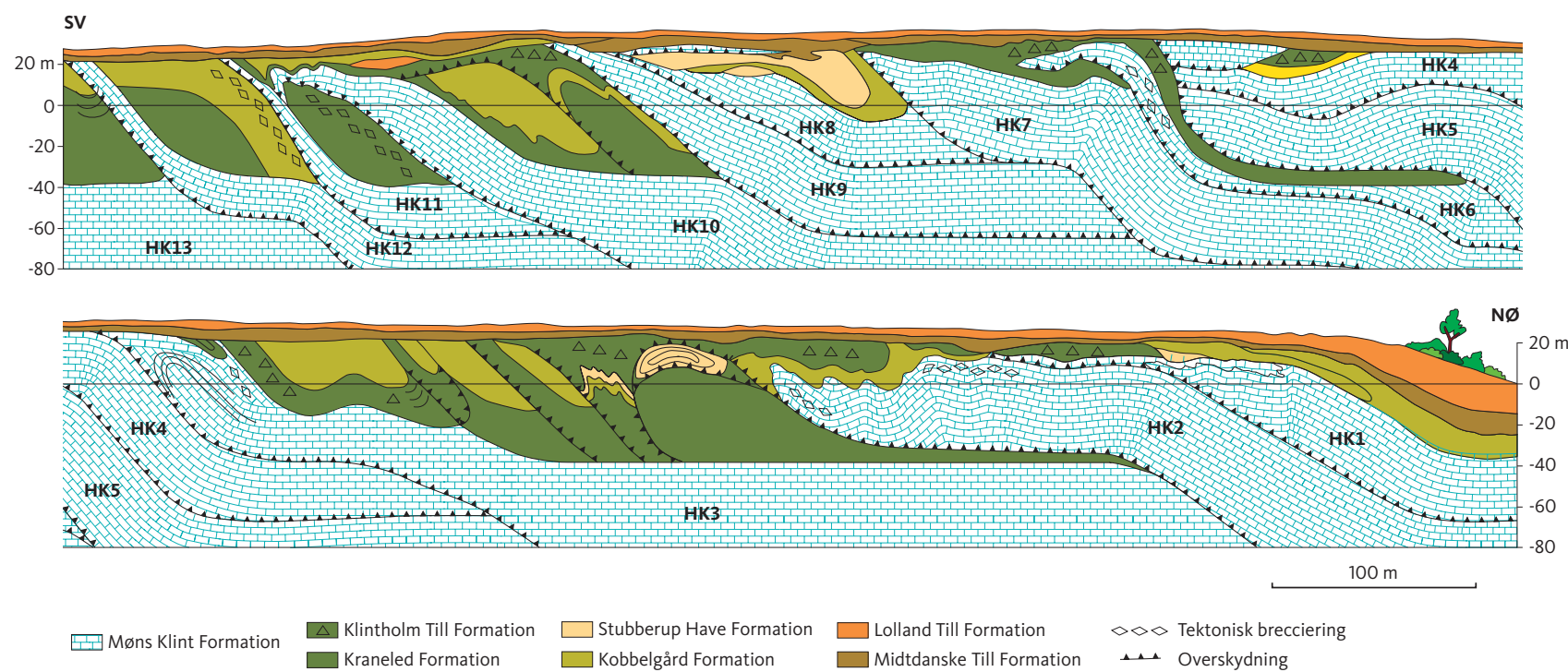

Fig. 28 Strukturen af Hvideklint baseret på nye opmålinger suppleret med informationer fra Stockmarr (1996). HK1-HK12 refererer til skrivekridtskiver nummereret fra nordøst mod sydvest. Disse betegnelser er også brugt i Fig. 29-39 fra Hvideklint.

Fig. 28. The structure of Hvideklint based on new measurements supplemented by information from Stockmarr (1996). HK1 to HK12 refer to individual chalk sheets numbered from northeast to southwest. These are also used in Figs 29-39 from Hvideklint.

100 år siden tolket som resultatet af glacialtektonik. Fra Den Skandinaviske Iskappe rykkede i sidste istid en isstrøm frem gennem Østersøen mod Kattegat. Ved isens front blev kridtskiverne med overliggende kvartære aflejringer skubbet op i glacialtektoniske komplekser på Møn og Rügen (Johnstrup 1874; Gripp 1948). Siden da har Møns Klint været betragtet som en nøglelokalitet for glacialtektonik (Fig. 27; Slater 1927; Aber et al. 1989; Pedersen 2000, 2014).

I en overordnet strukturel sammenhæng kan Møns Klint inddeles i et imbrikeret proksimalt kompleks mod syd, en antiform stak i den centrale del og lavt hældende forlandsoverskydninger i den distale del mod nord (Pedersen 2000). Desuden er især den nordlige del af klinten påvirket af overpræget deformation, som skyldes det sidste afsluttende isfremstød fra Skåne, inden isen smeltede fuldstændig væk fra Danmark for ca. 16000 år siden .

Det imbrikerede kompleks i den proksimale, sydlige del af klinten er karakteriseret af enkelte stejltstående skiver somf.eks. Hvidskud, St. Stejlbjerg og Sommerspir. Destrukturelle forhold for disse skiver er vist i blokdiagrammet på det geologiske kortblad (vignetten 'Stratigrafisk og strukturel opbygning af Møns Klint'). Det skal her bemærkes, at décollement-niveauet ligger ca. $100 \mathrm{~m}$ under havoverfladen (Fig. 42; Pedersen 2000). Det allersydligste parti er Jættebrinken, som består af tre skrivekridtskiver, der er skudt op over hinanden langs lavtliggende overskydninger og nu har en fladtliggende orientering (Fig. 27). Syd for Jættebrinken forekommer glaciale sedimenter i et hul, hvor den underliggende skrivekridtoverflade er under havniveau. Stien til stranden fra fyret på den sydlige pynt af Møns Klint går ned gennem den glaciale lagserie, som dog er skjult af tæt krat. Klintens sydlige del tolkes som det sted, hvor der var kontakt mellem den fremadskridende is og den deformerede lagpakke. Det moræneler, som er aflejret her, tolkes som tilhørende Lolland Till Formation, som ved en længerevarende aflejring af bundmoræne i den tektoniske depression bag de opskudte skiver har fået en forøget tykkelse.

Hundefangsfaldet adskiller Jættebrinken fra Hundefangsklinten længere mod nord, der er den første af de stej|tstående klinter i den proksimale zone (Fig. 27, 42). Denne zone strækker sig frem til Sommerspirpynten, hvor den brede rende Sandfaldet har fået sit navn efter den store mængde smeltevandssand, som findes her. Sandfaldet tolkes som et 'piggyback' bassin, hvor en smeltevandsflod gennemstrømmede dalen mellem Sommerspirskiven og skiven nord for Sandfaldet, mens skiverne blev bevæget fremefter af det glacialtektoniske pres. Skiven nord for Sandfaldet strækker sig fra Græderen og frem til Maglevandsfaldet (Fig. 27). Langs dens sider pålejrer sandet undersiden af Sommerspirskiven og oversiden af skiven ved Græderen. Sandet er samtidig moderat foldet $i$ en synklinal som et slæb langs overskydningen, hvilket viser, at umiddelbart efter sandet blev aflejret, blev det deformeret af de igangværende glacialtektoniske processer.

Dronningestolens strukturer tolkes som et resultat af en overskydning af flere skiver, som i deformationens tidlige fase blev placeret fladt oven på hinanden (Fig. 27 \& 42). Efterfølgende blev alle skiverne skubbet med op over en dybtliggende rampe, hvorved de blev bøjet i en hængende-blok antiklinal struktur (Pedersen 2000). Disse forhold fremgår af en detaljeret strukturel 

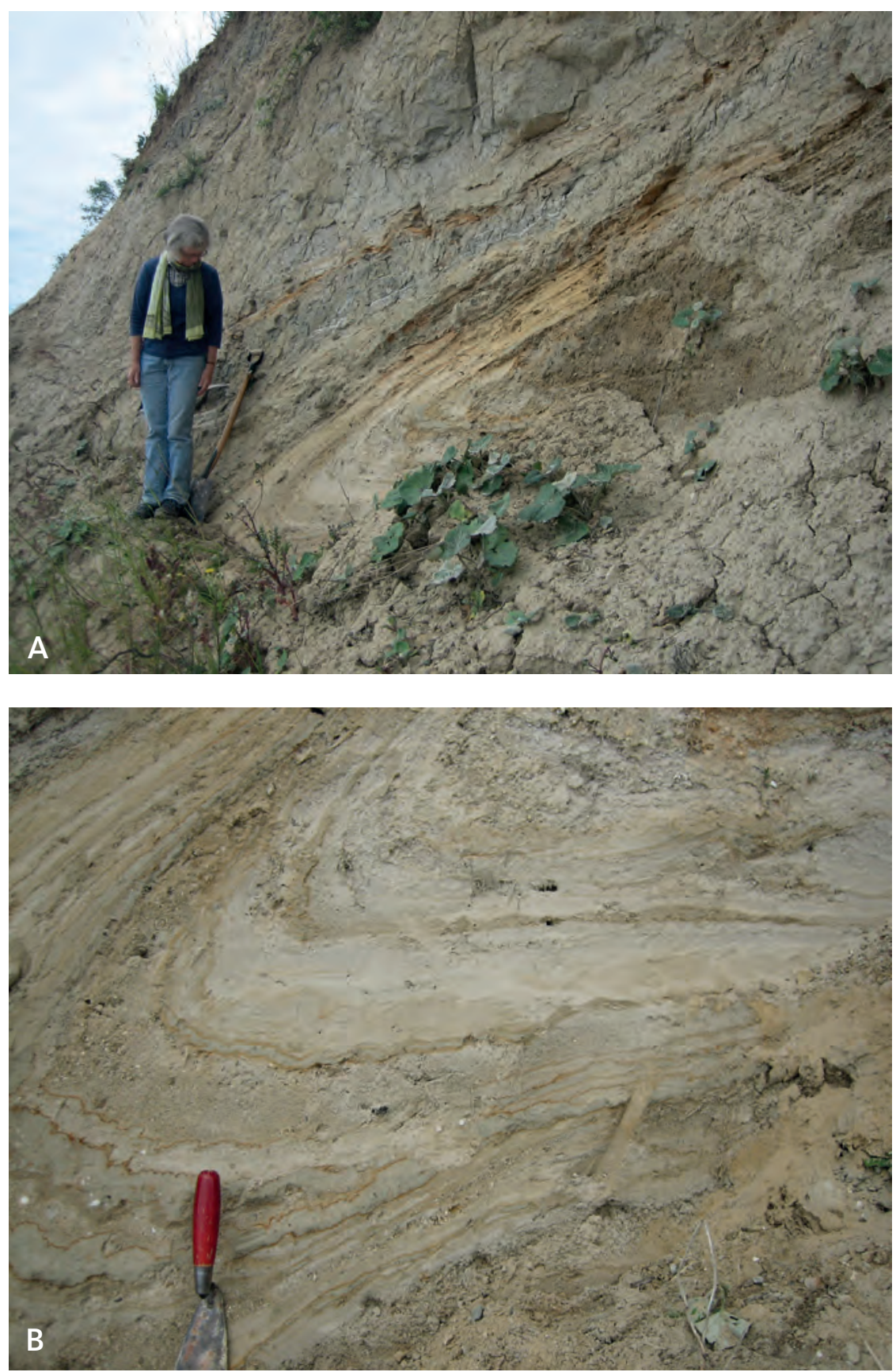

Fig. 29 Folder i Hvideklint. A: Overkippet synklinal i skive HK3 med $\varnothing$-V-orienteret foldeakse. Lyse glaciofluviale sandlag tilhørende Stubberup Have Formationen er indfoldet $i$ det mørkere Kobbelgård Formation ler. B: Næsen af den overkippede synklinal med vekslende lag af ler, silt og sand.

Fig. 29. Folds at Hvideklint. A: Overturned syncline in sheet HK3 with an E-W-oriented fold axis. The light glaciofluvial sand of the Stubberup Have Formation is folded into the darker clay of the Kobbelgård Formation. $\mathrm{B}$ : The nose of the overturned syncline includes alternating layers of clay, silt and sand. undersøgelse neden for GeoCenter Møns Klint (Pedersen 2003; Pedersen \& Gravesen 2009).

I den distale del af det glacialtektoniske kompleks har overskydningerne en moderat hældning mod syd (Fig. 27, 42). Overskydningerne går ind over forlandet, som består af ler tilhørende Kobbelgård Formationen; det fremgår af en opmåling ved Nonnebrinken-Liselund foretaget under forfatternes feltarbejde. En særlig struktur er her en 'roll-over' antiklinal, som er blottet neden for Nonnebrinken.

\section{Hvideklint}

Hvideklint er en mere end $1 \mathrm{~km}$ lang kystklint ved den vestlige del af Hjelm Bugt. Klintprofilet stryger NØ-SV og giver et erosionssnit gennem bakkelandet på den sydvestlige del af Møn (Fig. 28). Kystklinten er omkring 20 $\mathrm{m}$ høj og består af mere end 13 skrivekridtskiver med mellemlejrede glaciale aflejringer, der på lang afstand ses som en lysende hvid klintstrækning.

Opbygningen af Hvideklint og dens interne strukturers arkitektur er betinget af tre glaciodynamiske forhold: (1) Skiver af skrivekridt blev først skudt op af Hovedfremstødet fra nordøst mod sydvest. (2) Komplekset af opskudte skrivekridtskiver blev afslutningsvis deformeret af det Ungbaltiske Isfremstød fra sydøst mod nordvest. (3) Kombinationen af skrivekridt og ler medførte en intensiv brecciering og dannelse af mudderdiapirer (Aber 1979; Berthelsen 1979; Stockmarr 1996). Et 

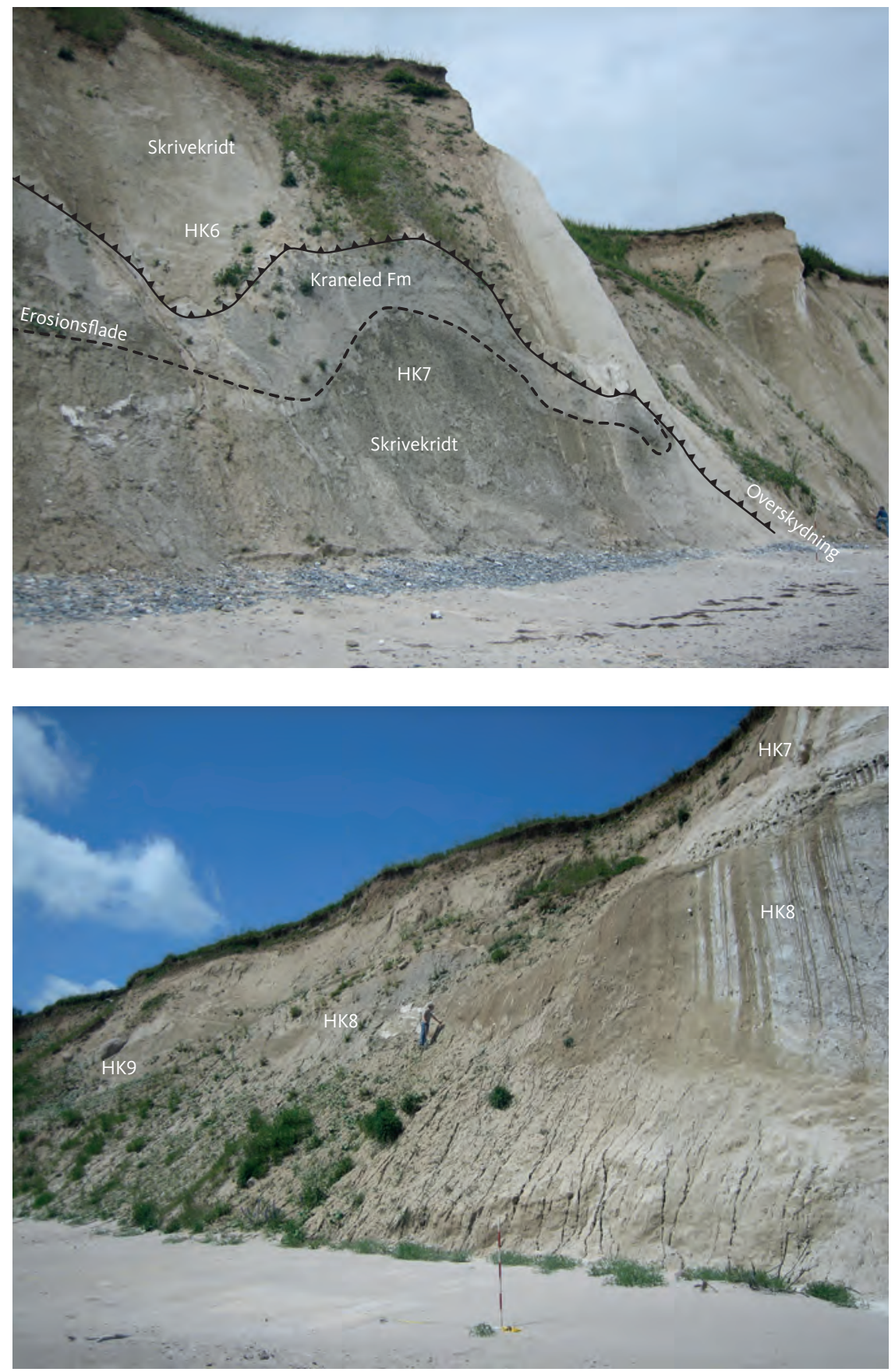

Fig. 30 Overskydning i Hvideklint, som adskiller skiverne HK6 og HK 7 med en isoklinalt foldet synklinal af ler fra Kraneled Formationen. Overskydningen kan følges gennem hele fotoet.

Fig. 30. Thrust fault at Hvideklint separating sheets HK6 and HK7 with an isoclinally folded syncline consisting of Kraneled Formation clay. The thrust fault can be traced throughout the photo.

Fig. 31 Overskydninger mellem skive HK7, HK8 og HK9 i Hvideklint med fronten af skive HK9.

Fig. 31. Thrust faults between sheets HK7, HK8 and HK9 at Hvideklint together with the front of sheet HK9. tværsnit af Hvideklints strukturer vist i Fig. 28 er baseret på opmåling af klinten, målinger af strygning og hældning for lagplaner og overskydningsplaner, måling og konstruktion af foldeakser kombineret med overvejelser relateret til skrivekridtskivernes volumen (balancerede tværprofiler, Pedersen 2005). Denne tolkning støttes af det konstruerede kort over skrivekridtoverfladens højdeforhold (Fig. 2) og tværsnit E-F på kortbladet, som begge er baseret på boredata fra især det vestlige Møn. Det tolkede tværsnit kan tillige opfattes som en model for bakkelandet omkring Hjelm og Nørre Frenderup.

Tværsnittets nulpunkt er ved en bæk, som løber ud over stranden neden for Ørbæklund. De første (nordøstlige) ca. $300 \mathrm{~m}$ af Hvideklint (HK) domineres af skrivekridtskiverne HK1 og HK2. På ryggen af HK1 forekommer de nedre kvartære enheder af Kobbelgård Formationen i en smal, overkippet synklinal. Denne foldning har tillige påvirket den øverste del af skrivekridtet i HK1, som dog ved forskydningsspænding er omdannet til en kridt-glacitektonit. Foldningen afskæres af en overskydningsflade, hvorpå den Midtdanske Till Formation hviler. På toppen overlejrer Lolland Till Formationens bundmoræne hele kystprofilet med en diskordant grænse. Overskydningsgrænsen mellem HK1 og HK2 er ikke altid tydeligt blottet, men kan identificeres ved, at den sydvestlige flanke i HK1s hængende antiklinal står næsten 

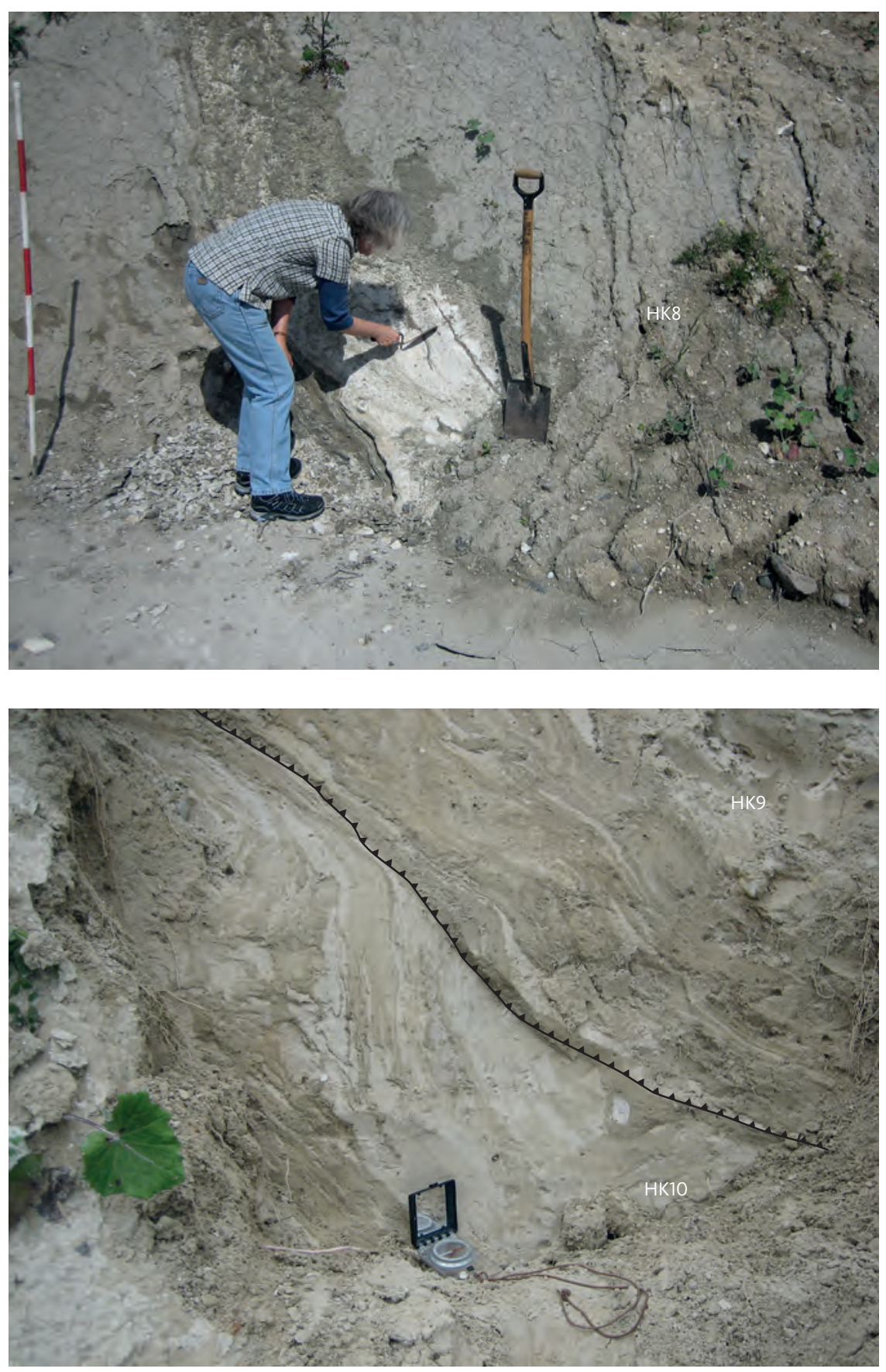

Fig. 32 Intenst deformeret skrivekridt i skive HK8 ved basis af Hvideklint, skiftendefraskrivekridt-glacitektonittilbreccierede skrivekridt-moræneaflejringer.

Fig. 32. Intensely deformed chalk in thrust sheet HK8 at Hvideklint, grading from chalk-glacitectonite to brecciated chalk-till deposits.
Fig. 33 Foldede og opskudte lag i Hvideklint, der forsætter dele af Kraneled, Klintholm Till og Kobbelgård Formationerne mellem skiverne HK9 og HK10.

Fig. 33. Folded and thrust-displaced layers at Hvideklint, representing parts of the Kraneled, Klintholm Till and Kobbelgård Formations between the sheets HKO and HK10. vinkelret på ryggen af en svagt $\mathrm{N} \emptyset$-hældende lagstilling i overfladen af HK2. Forholdene er mere vanskelige at udrede hen mod næsen af HK2, hvor glacialtektonisk brecciering bliver mere og mere fremherskende. Næsen af HK2 er skudt op langs en ca. $45^{\circ} \mathrm{N} \varnothing$-hældende overskydning, hvor Kobbelgård Formationens ler er overkippet på sydvestflanken af den opskudte hængende-blok antiklinal.

Mellem blotningen af skrivekridtet i næsen af HK2 og en anden blotning af skrivekridtet i ryggen af HK3 findes en $120 \mathrm{~m}$ lang strækning med tilskredede og tilgroede glaciale aflejringer. I den nordøstlige del af denne strækning optræder en overkippet synklinal.
Dens foldeakse har retningen $\varnothing-\mathrm{V}$ svarende til, at opskydningen er sket fra syd (Fig. 29). Synklinalen og den hermed forbundne overskydning hælder stejlt mod syd. Det er således en overpræget foldning, hvor strukturer hidrørende fra de nordøstfra opskudte skiver er redeformeret af en opskydning ved fremrykningen af den Ungbaltiske Is fra syd mod nord. Den fra syd overkippede synklinal aftegner sig tydeligt i de laminerede og tyndbænkede smeltevandssedimenter i Kobbelgård Formationen (Fig. 29).

Op mod ryggen af HK3 forekommer tre til fire imbrikerede skiver domineret af leret i Kraneled, Klintholm Till og Kobbelgård Formationerne. Da der ikke er blotninger 

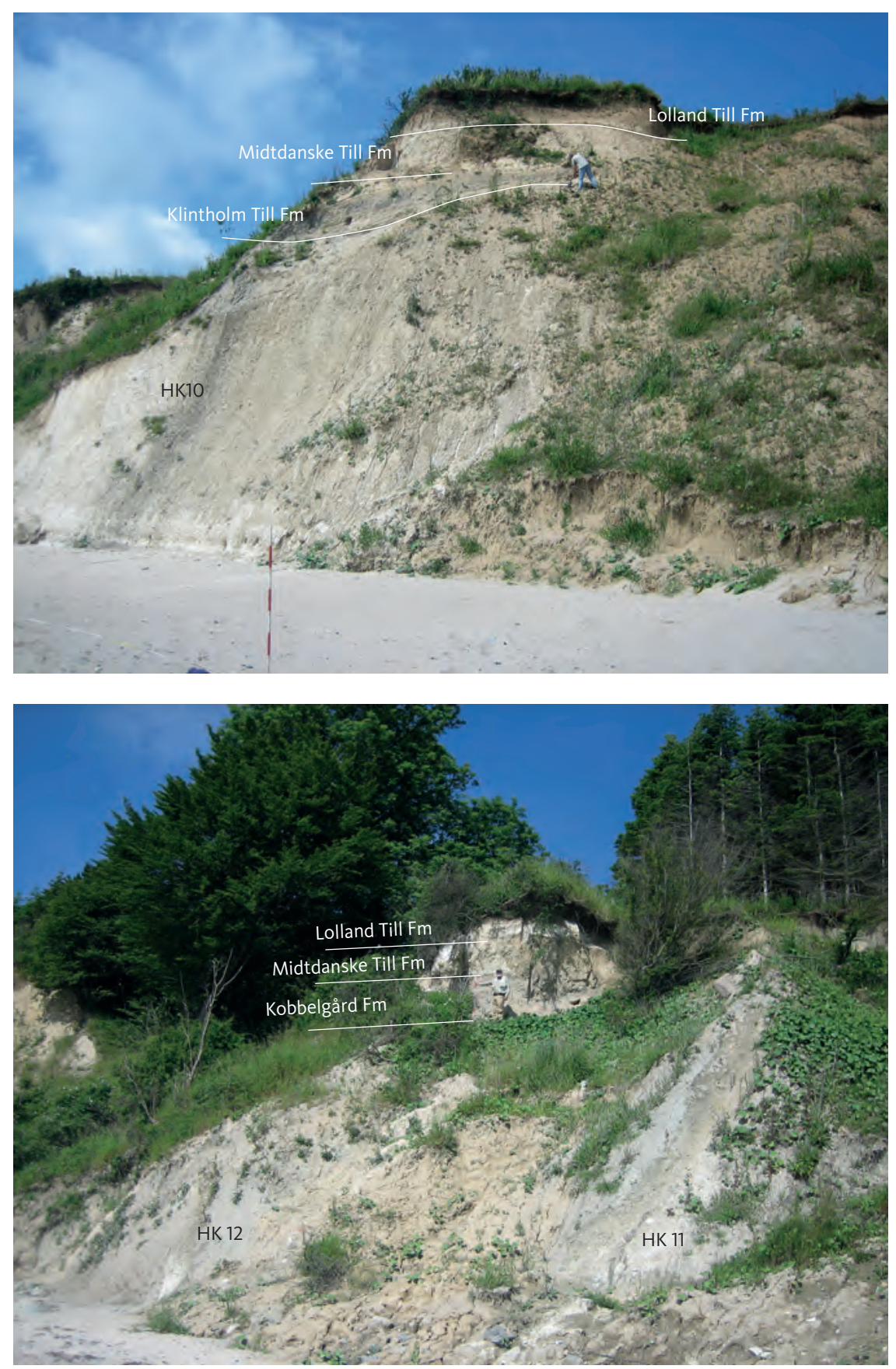

Fig. 34 Skrivekridt ved fronten af skive HK10 i Hvideklint overlejret af en serie kvartære lag omfattende Kraneled, Klintholm Till, Kobbelgård, Midtdanske Till og Lolland Till Formationerne.

Fig. 34. Cretaceous chalk at the front of sheet HK10 at Hvideklint, overlain by a succession of Quaternary deposits including the Kraneled, Klintholm Till, Kobbelgård, Mid Danish Till and Lolland Till Formations.

Fig. 35 De stejltstillede skrivekridtskiver HK11 og HK12 i Hvideklint, overlejret diskordant af den næsten horisontalt afsatte Lolland Till Formation med en linse af skrivekridt-glacitektonit. Person i midten af billedet som skala.

Fig. 35. The steeply dipping chalk sheets HK11 and HK12 at Hvideklint, truncated by the almost horizontally deposited Lolland Till Formation including a lens of chalk-glacitectonite. Person for scale in centre of photo. af skrivekridt mellem lerskiverne, er de tolket som tektonisk båret på ryggen af HK3. Bedømt ud fra profiltolkningen har skiverne deres rod langs inkonformiteten på toppen af skrivekridtet 35 m u.h. Imidlertid må det forventes, at décollement-niveauet for selve skiverne af skrivekridt ligger mindst $15 \mathrm{~m}$ dybere, svarende til skivernes maksimale tykkelse som de er blottet i klinten. På tværprofilet antydes det, at den basale décollementzone ligger i kote $-80 \mathrm{~m}$, men i denne dybde ville kun skrivekridt forskubbes hen over faststående skrivekridt.

Skrivekridtskiverne HK3, HK4 og HK5 danner et sammenhængende kompleks, der kan tolkes som en 'antiformal stack'. Det vil sige, at skiverne først er skubbet lateralt hen over hinanden, inden de sammen er skudt op over den underliggende rampe under HK5. Hen over næsen af HK4 optræder en splint af en skive, der tolkes som en opskydning af skrivekridt skubbet op fra syd.

Skrivekridtskiven HK6 er en tynd skive, der er skudt ind over den relativt tykke skive HK7. Den overskydning, som adskiller de to skiver, optræder sammen med en isoklinalt foldet synklinal af mørkt ler, der kan henføres til Kraneled Formationen (Fig. 30). Skrivekridtet i HK6 og den øverste del af HK7 er opbrudt og breccieret og kan bedst betegnes som en skrivekridt-glacitektonit. Næsen af HK7 er skudt op over ryggen af overskydningsskiven HK8, hvor flere kvartære lag er foldet i en overkippet 

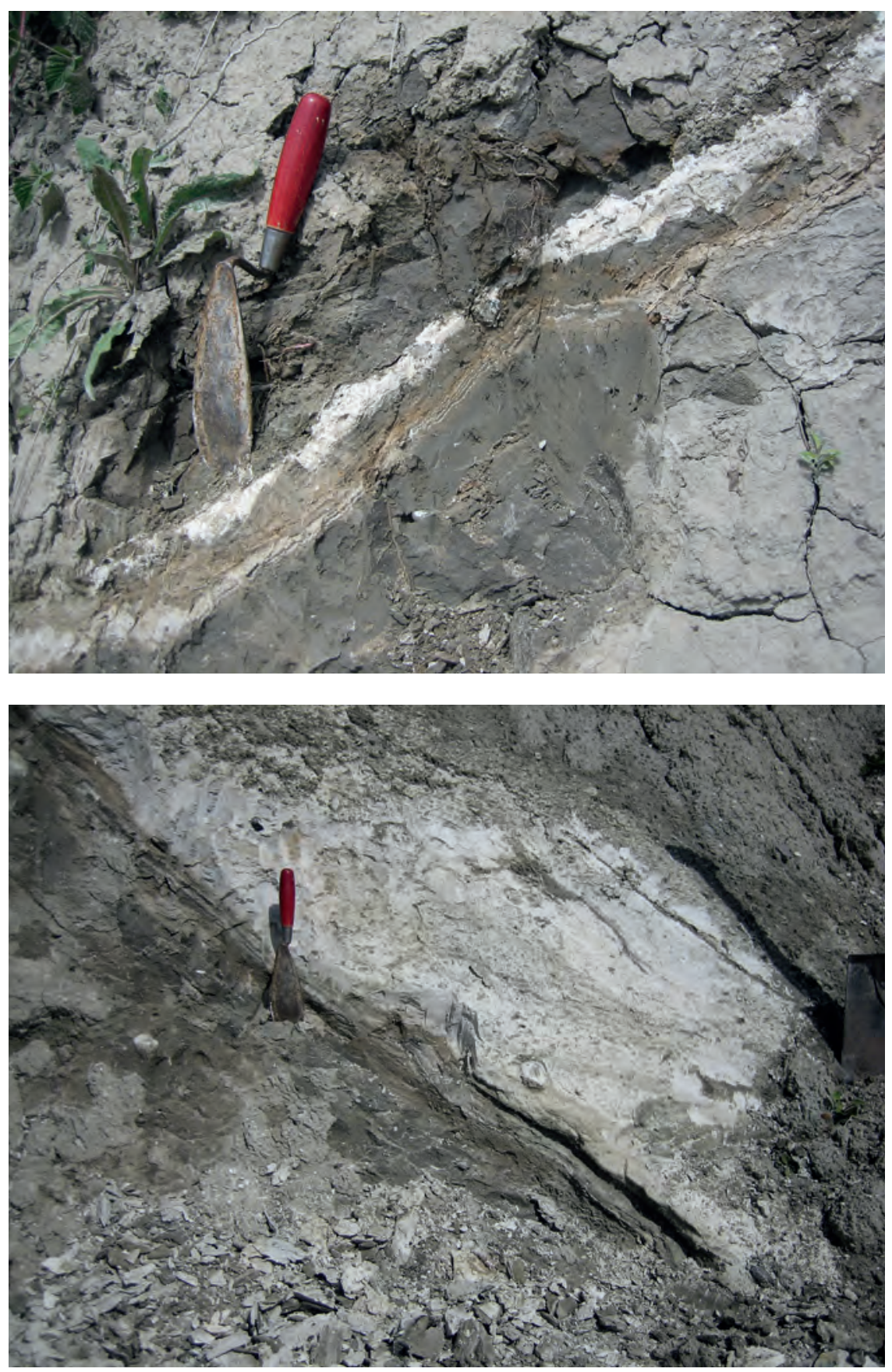

Fig. 36 Tynde lag af skrivekridt-glacitektonit i Hvideklint, skubbet op over de allerede opskudte skiver HK1-HK12. De tynde lag og slirer af skrivekridt er valset ind i mørkt ler tilhørende Kobbelgård Formationen ved sheardeformation.

Fig. 36. Thin layers of chalk-glacitectonite at Hvideklint, which were squeezed up above the existing pile of chalk sheets HK1-HK12. The thin chalk layers and lenses have been sheared into the dark clay of the Kobbelgarrd Formation.

Fig. 37 Slirer og tynde lag af ler i det overskydnings-breccierede skrivekridt i skive HK8 i Hvideklint. Den oprindelige lagdeling i skrivekridtet er ødelagt, og bjergarten er omdannet til en glacitektonit.

Fig. 37. Lenses and thin layers of clay in the chalk of sheet HK8 at Hvideklint, deformed by thrust faulting. The chalk has completely lost its primary sedimentary layering and has been transformed into a glacitectonite. synklinal under overskydningssålen af HK7. HK8 er en relativt kort skive, som blev båret på ryggen af HK9. En endnu mindre og tyndere skive af skrivekridt-glacitektonit er ved sålen af den Midtdanske Till Formation slæbt diskordant hen over næsen af HK8 og HK9. Spidsen af skrivekridtskiven HK9 er så kraftigt sheardeformeret, at den er en mellemting mellem en skrivekridt-glacitektonit og en breccieret skrivekridtmoræne (kridt-till, Fig. 31, 32).

Mellem skrivekridtskiverne HK9 og HK10 optræder to skiver med foldede og forskudte enheder af Kraneled, Klintholm Till og Kobbelgård Formationerne. Den øverste af disse skiver er foldet i en overkippet antiklinal, og langs overskydningszonen mellem de to skiver er lagene intensivt deformeret af reverse forkastninger (Fig. 33). På ryggen af HK10 optræder mørkt ler oven på skrivekridtoverfladen, som kan henføres til Kraneled og Klintholm Till Formationerne. Stærkt reverst forskudte, sandede lag består af vekslende indslag af Kobbelgård Formationen. Ved den frontale del af HK10 findes tre bundmoræner, hvor Klintholm Till Formationen er adskilt fra den Midtdanske Till Formation og Lolland Till Formationen ved sandede og lerede indslag af Kobbelgård Formationen (Fig. 34).

Skrivekridtskiverne HK11 og HK12 er to relativt tynde og stejltstående skiver (Fig. 35). På grund af sheardeformationen optræder der både lag og linser af sort ler 

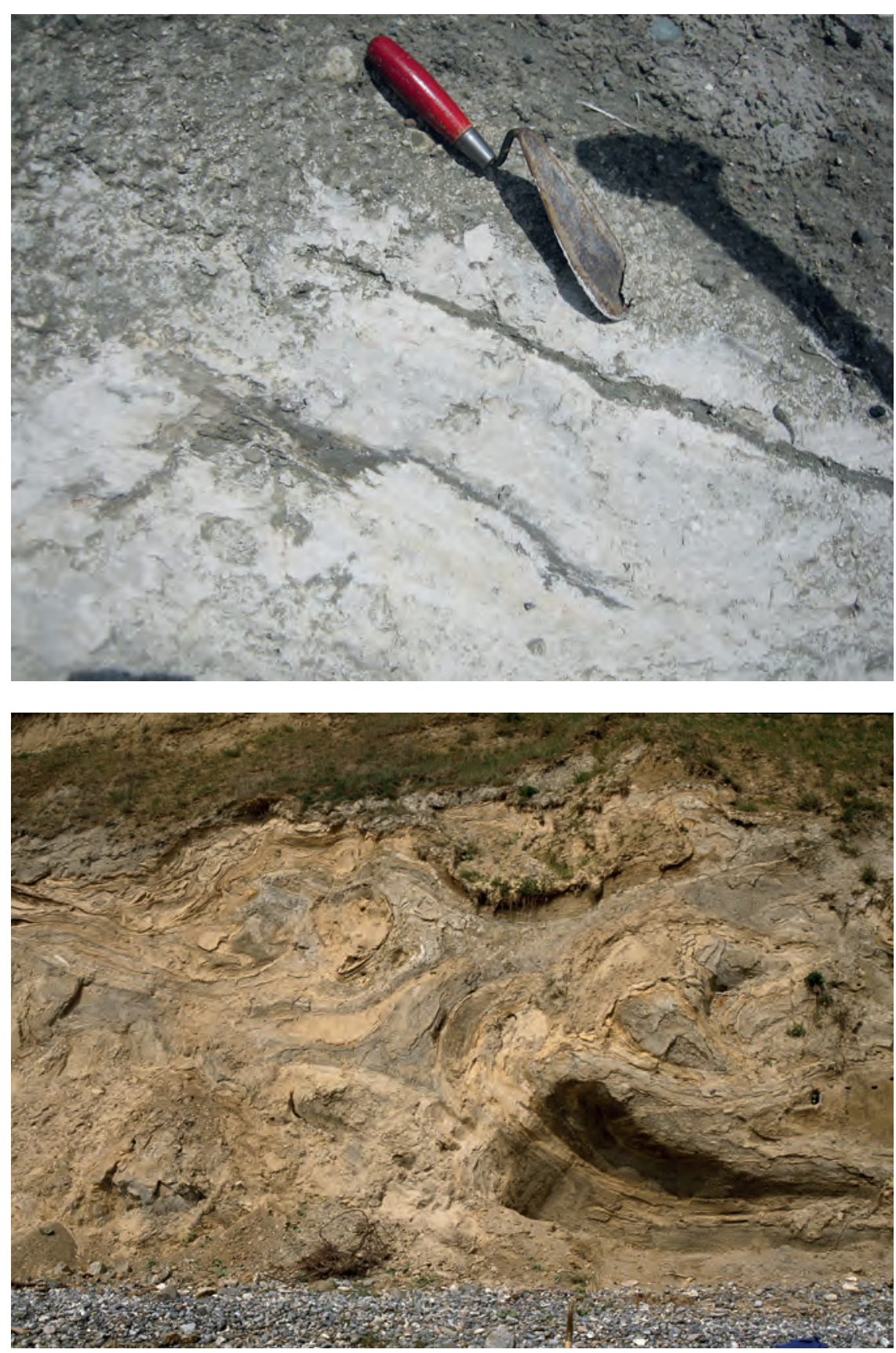

Fig. 38 Breccierede klaster af skrivekridt i leret langs sålen af overskydningsskiverne i Hvideklint. På grund af det meget store lerindhold i Kraneled og Kobbelgård Formationerne er klintens sydvestlige del ofte delvist dækkket af mudder.

Fig. 38. Brecciated clasts of chalk in mud along the sole of the thrust faults at Hvideklint. The large mud content in the Kraneled and Kobbelgaird Formations commonly blurs exposures of the south-western part of the cliff.

Fig. 39 Mudderdiapirisme i Hvideklint dannet under glacialtektonisk deformation af vandmættede leraflejringer. Blotningen er ca. $2 \mathrm{~m}$ høj. Foto: Tove Stockmarr (1996).

Fig. 39. Mud diapirism at Hvideklint formed during glacial tectonic deformation of water-saturated clay deposits. The exposure is almost $2 \mathrm{~m}$ high. Photo: Tove Stockmarr (1996). i skrivekridt og lag og slirer af skrivekridt i mørkt ler (Fig. 36, 37). Fra HK11 mod sydvest tiltager forekomsten af leraflejringer, fortrinsvis fra Kraneled og Kobbelgård Formationerne, hvilket har medført forøget nedskridning og tilmudring af kystprofilet (Fig. 38). Endnu en skrivekridtflage, HK13, er identificeret længere mod sydvest i retning mod Hjelm Nakke. Her er de tektoniske forhold dog så komplekse, at det ikke giver mening at optegne dem i et tværprofil. Et eksempel på denne kompleksitet i deformationsmønsteret ses i forekomsten af mudderdiapirer, som dannes, hvor vandmættede leraflejringer udsættes for glacialtektonisk deformation (Fig. 39).

\section{Glacialdynamisk udvikling}

Pedersen (2012a) har foreslået en glaciodynamisk sekvensstratigrafi for glaciale aflejringer $i$ et terrestrisk område, som også omfatter aflejringernes glaciale deformation både ved dannelsen af de glacialtektoniske komplekser og selve de breccierede litologier (de såkaldte glacitektoniter, Pedersen 1988, 2014; Pedersen et al. 2018).

Til en glacialdynamisk hændelse svarer en glacialdynamisk sekvens. Basis af en glacialdynamisk sekvens er det dybeste niveau, som påvirkes af den glacialdynamiske hændelse. I den komplette glacialdynamiske sekvens er det décollementniveauet for den glacialtektoniske deformation, dvs. det dybeste niveau, langs 


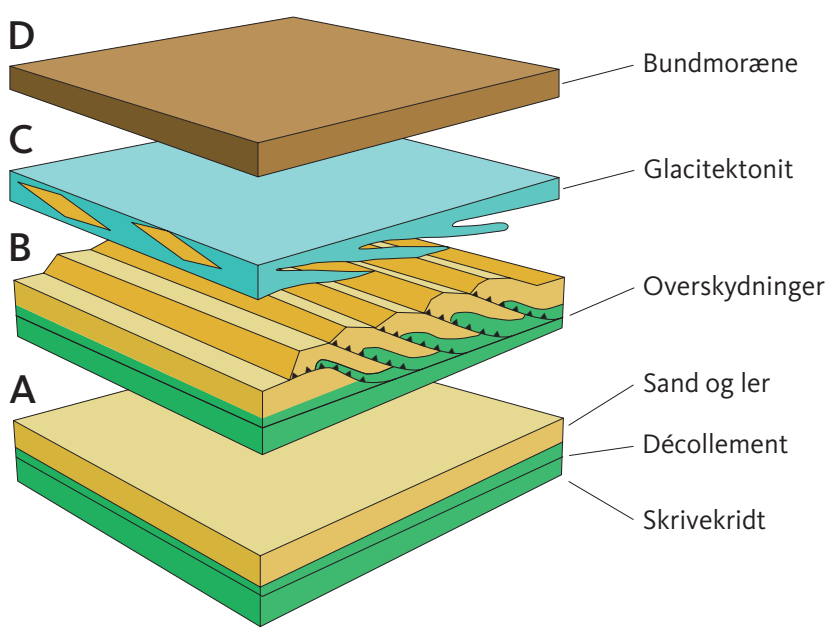

Fig. 40 Konceptuel illustration af det glacialdynamiske sekvensstratigrafiske system (fra Pedersen 2012a). A: Beliggenheden af den basale décollementzone i toppen af skrivekridtet. B: Dannelsen af imbrikerede overskydningsskiver bestående af skrivekridt og glaciale aflejringer. C: Dannelsen af glacitektonit ved sålen af den overskridende is. D: Afsluttende aflejring af bundmoræne oven på glacitektoniten.

Fig. 40. The concept of glaciodynamic sequence stratigraphy (after Pedersen 2012a). A: Location of the basal décollement zone in the upper part of the chalk. B: Formation of thrust fault imbricates consisting of chalk and glacial deposits. C: Truncation of the glacier sole during formation of glacitectonite. D: Final deposition of lodgement till above the glacitectonite.

hvilket der sker en glacialtektonisk forskydning. Herover følger de enheder, som indgår i det glacialtektoniske kompleks. De kan bestå af prækvartære formationer som f.eks. glacialt deformeret skrivekridt og præ- eller proglaciale formationer såsom smeltevandsserier. Det glacialtektoniske kompleks afskæres af en vinkeldiskordans, hvorover en glacitektonit dannes ved sålen af en bundmoræne. Toppen af den glacialdynamiske sekvens er overfladen af den bundmoræne, som blev aflejret under det isfremstød, der forårsagede den glacialdynamiske hændelse (Fig. 40). På Møn kan man skelne mellem fire glacialdynamiske sekvenser: Klintholm, Hvideklint, Møns Klint og Aborrebjerg.

\section{Klintholm Glacialdynamiske Sekvens}

Kystprofilerne øst og vest for Klintholm Havn indeholder nogle dislocerede enheder af smeltevandsler og -sand samt nogle diamikte aflejringer, der enten kan være bundmoræneler eller dropstens moræneler (se diskussionen af de diamikte aflejringers dannelse i Houmark-Nielsen 1994). Ved basis af de glaciale aflejringer forekommer skrivekridt og varierende mængder af skrivekridtskiver, der er indarbejdet i de glaciale sedimenter. Skiverne er skubbet op fra øst mod vest og overlejres diskordant af mørkegråt bundmoræneler. Denne sekvens betegnes Klintholm Glacialdynamiske Sekvens. Den glacialdynamiske hændelse skete under det tidligste (Ristinge) isfremstød i den tidlige til mellemste del af Weichsel for ca. 55000 til 50000 år siden. Klimatisk efterfølges hændelsen af Sandnæs Mildningen.

\section{Hvideklint Glacialdynamiske Sekvens}

Det glacialtektoniske kompleks på Hvideklint består af ca. 15 skiver af skrivekridt, der bærer en varierende mængde af glaciale aflejringer på ryggen over top-skrivekridt-inkonformiteten. Alle de opskudte skiver skæres af den overliggende Midtdanske Till Formation, hyppigt med en 0,5-1 m tyk, udtværet enhed af skrivekridt-glacitektonit ved bundmorænens sål. Denne sekvens betegnes Hvideklint Glacialdynamiske Sekvens, hvis årsag er det dominerende isfremstød, der med et kildeområde i det centrale Sverige spredte sig ud til Hovedopholdslinjen i Danmark, Nordtyskland og Polen m.v. (NØ-Isfremstødet). På Møn har isfremstødet retning fra nordøst mod sydvest. Foruden Hvideklints glacialtektoniske kompleks kan den anden fase af Præstebjerg bakkekomplekset inddrages i denne glaciodynamiske sekvens. Hændelsen skete i sidste halvdel af Weichsel-istiden på det tidspunkt, hvor det seneste glaciale maksimum (LGM) indtrådte.

\section{Møns Klint Glacialdynamiske Sekvens}

Det glacialtektoniske kompleks på Høje Møn er arkitektonisk opbygget som en samlet enhed, der fra syd er skubbet op mod nord. Enhedens bund befinder sig ved en décollementflade ca. 100 m u.h. (Pedersen 2000, 2003; Pedersen \& Gravesen 2009). Ved konstruktionen af dybden til décollementfladen er principperne for balancerede glacialtektoniske tværprofiler benyttet som beskrevet af Pedersen (2005, 2006). Over décollementfladen kan skrivekridtet ikke betragtes som faststående. Selve det glacialtektoniske kompleks har en klassisk opbygning i en proksimal, central og distal del fra syd mod nord. Toppen af skrivekridtskiverne og de mellemlejrede glaciale aflejringer er afskåret af Lolland Till Formationens bundmoræne, der hyppigt har en medslæbt sål af skrivekridt-glacitektonit. Denne sekvens betegnes her som Møns Klint Glacialdynamiske Sekvens. Den tilhørende glacialdynamiske hændelse tilskrives den hurtigt fremadskridende Ungbaltiske Is for ca. 18000 år siden. Denne hændelse er tillige ansvarlig for fase 3 og måske 4 i Præstebjerg bakkekomplekset (se kapitlet Landskabets udformning og dannelse nedenfor). Det er den glacialdynamiske dannelse af Møns Klint, der er ansvarlig for den overordnede udformning af hele Møn og specielt kysten ud mod Hjelm Bugt (Fig. 41) samt den overprægede deformation af Hvideklint. 


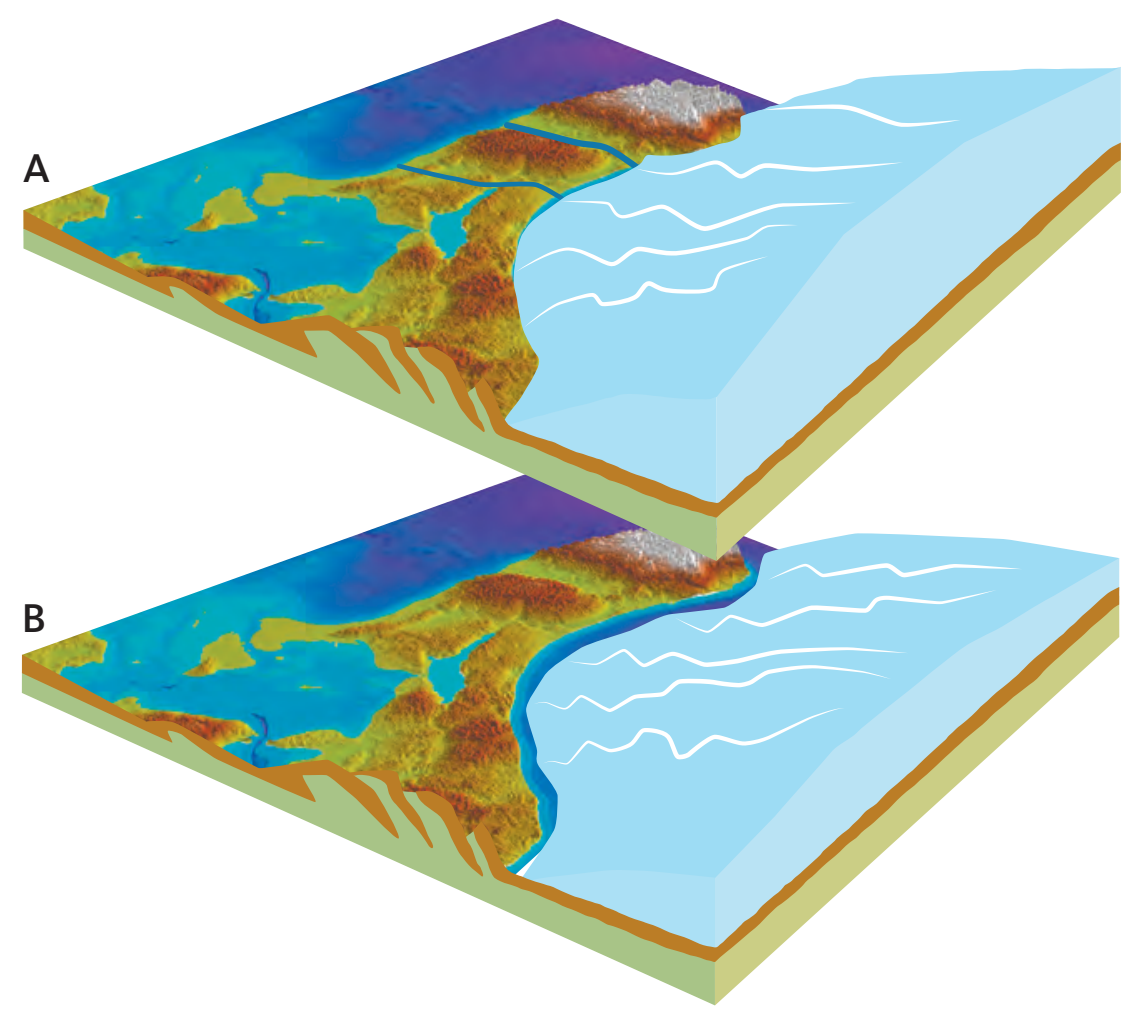

Fig. 41 Blokdiagrammer af Møns landskabsdannelse foran den Ungbaltiske Is. A: Den Ungbaltiske Is i loben i Hjelm Bugt. B: Blotning af det buede bakkeforløb på Møn under afsmeltningen af den Ungbaltiske Is. Bemærk, at bakkerne skæres af smeltevandsstrømme fra gletsjerranden langs sydkysten af Møn.

Fig. 41. Block diagrams showing the formation of Møn's hilly landscape in front of the Young Baltic Ice. A: The Young Baltic Ice occupying the depression in Hjelm Bugt. B: Exposure of an arcuate, hilly landscape during meltback of the ice. Note that the hills are cut by valleys formed by meltwater spillways from the adjacent ice margin along the south coast of Møn.

\section{Aborrebjerg Glacialdynamiske Sekvens}

Den nordlige halvdel af det glacialtektoniske kompleks på Møns Klint er overpræget af en glacialtektonisk opskydning fra nordøst (Fig. 42; Pedersen 2000). Det bedste eksempel på dette er overskydningen af skrivekridtskiven ved Vitmunds Nakke, som tydeligt er skubbet op fra nordøst mod sydvest, og som også fortsætter Lolland Till Formationen og den Midtdanske Till Formation samt ældre glaciale enheder. Ved en analyse af dobbeltfoldningens struktur ses det, at netop Aborrebjerg danner kulminationen af en fold på en fold (Fig. 43). Sekvensen er derfor benævnt Aborrebjerg Glacialdynamiske Sekvens.

Opskydningen svarer til et recessivt isfremstød fra området nordøst for Møn. Herfra må den Ungbaltiske Is under sin tilbagesmeltning have rykket en 'piedmont'-formet istunge frem. En sydvestrettet isfront herfra dislocerede de allerede forskubbede kridtskiver. Ifølge de gængse modeller for tilbagesmeltningen af den Ungbaltiske Is (Houmark-Nielsen 2010, HoumarkNielsen et al. 2017) må dette genfremstød være foregået for ca. 16000 år siden.

\section{Landskabets udformning og dannelse}

\section{Geomorfologisk beskrivelse}

Den følgende geomorfologiske beskrivelse er baseret på det geologiske kort og en højdemodel over Møn (Fig. 44).

\section{Glacialtektonisk parallelbakket landskab}

Det mest karakteristiske ved Høje Møn er de langstrakte, parallelle bakkerygge adskilt af langstrakte snævre dalstrøg. Bakkeryggene består af de glacialtektonisk opskudte skrivekridtskiver, og talrige steder i Store Klinteskov træder skrivekridtet frem i overfladen, hvilket især er tydeligt efter kraftigt stormvejr, hvor rodvæltere giver et indsyn i skovbundens bestanddele. I den sydlige del af Klinteskovens bakkekompleks er ryggenes retning $\emptyset$ Ø-V. Karakteristiske eksempler herpå er Gråryg med den langstrakte Nælderende nord for Gråryg. Længere mod nord begynder strygningen at dreje mod ØS $\varnothing-V N V$, som det er tilfældet med det dalstrøg, hvori Siesøerne ligger, og den nordfor beliggende bakkeryg Siesø Bjerg. Den ås, der går ind i skoven fra Dronningestolen, kan ligeledes betragtes tilhørende det omtrent $\emptyset$-V-strygende bakkesystem. Længere mod nord ændrer bakkeryggene markant retning til $S \varnothing-N V$. Enkelte af bakkeryggene længst ude mod klinten drejer helt op til retningen SS $\varnothing$-NNV, og den samme retning kan følges i sølavningerne fra Hunesø til Liselund.

Ud fra den glacialtektoniske tolkning af Møns Klint komplekset kan bakkerne klassificeres som sammensatte rygge. Andringerne i deres retning er tolket som resultatet af et istryk først fra sydsydøst, som tilskrives den Ungbaltiske Is. Dette tidligste kompleks af bakkerygge blev mod slutningen af istiden overpræget af et isfremstød fra Skåne, som med retning fra nordøst har 
Taglagt vifte

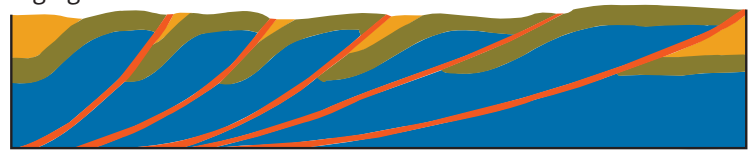

Antiform stak
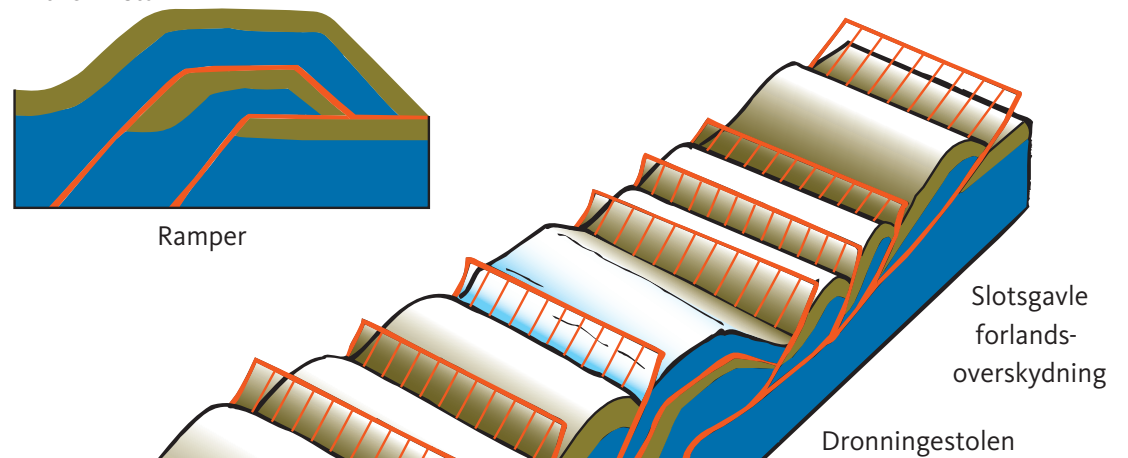

antiform stak

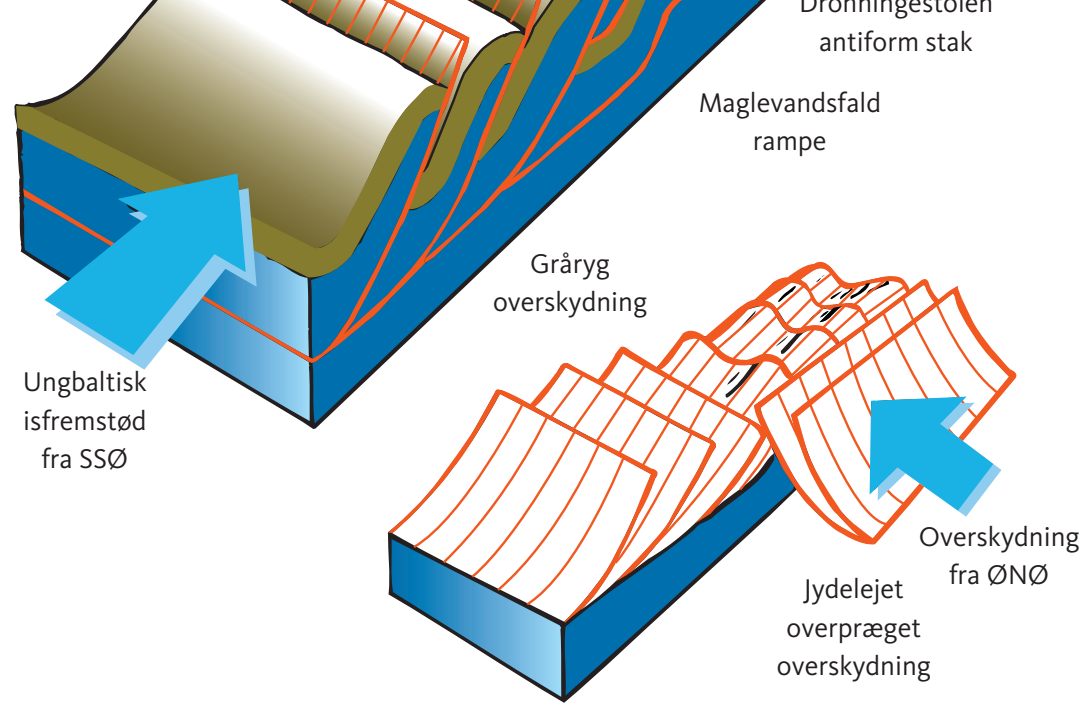

Fig. 42 Møns Klints strukturelle udvikling (efter Pedersen 2000). Blå: skrivekridt. Brun og orange: glaciale aflejringer. Røde linjer: overskydninger. Blå pile: istryksretninger fra henholdsvis SS $\varnothing$ og $\varnothing N \varnothing$.

Fig. 42. The structural evolution of Møns Klint (after Pedersen 2000). Blue: chalk. Brown and orange: glacial deposits. Red: thrust faults. Blue arrows show the directions of ice push from the SSE and ENE, respectively.
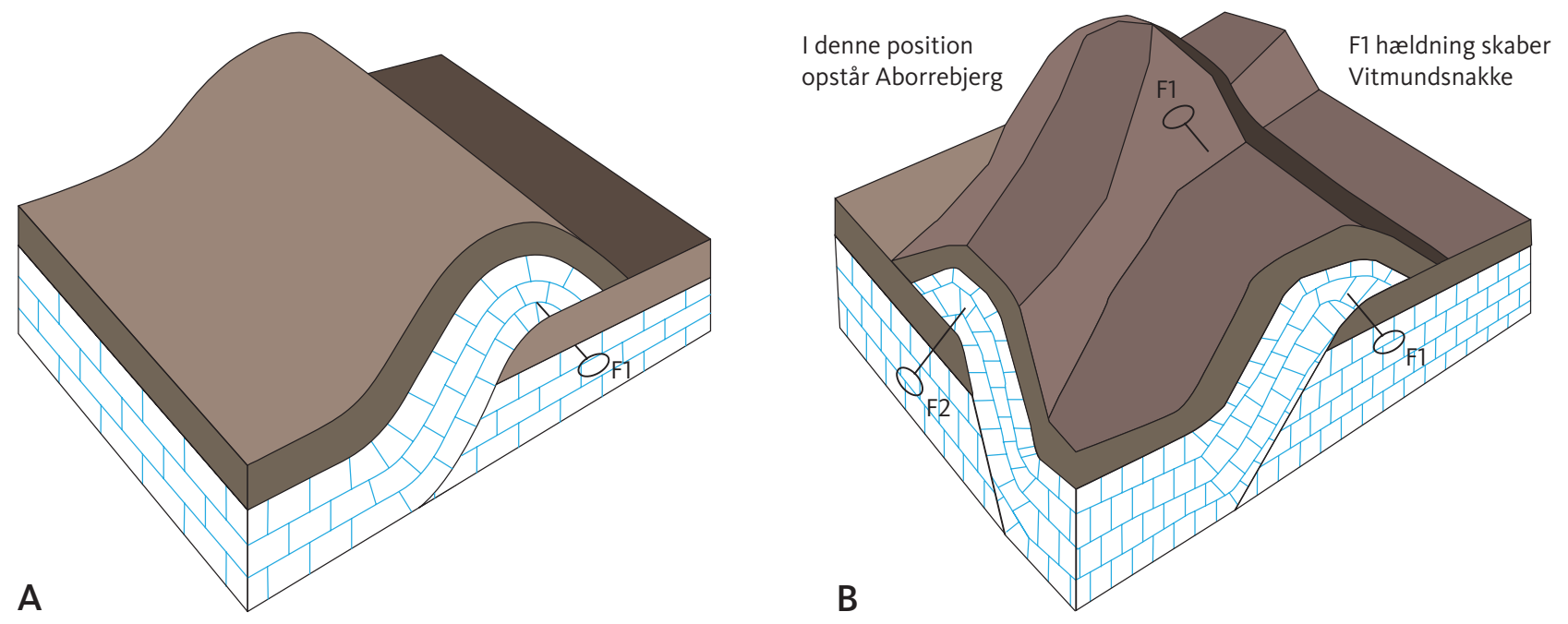

Fig. 43 Dannelsen af Aborrebjerg og Vitmunds Nakke. Aborrebjerg er det højeste punkt på Møn. At netop dette punkt er så højt, tolkes som resultatet af to forskellige hændelser: A: Opskydning af skrivekridtskiver fra syd under det Ungbaltiske Isfremstød (F1). B: Forkastning forårsaget af genfremstød af is akkumuleret i det sydlige Sverige (F2).

Fig. 43. Formation of Aborrebjerg and Vitmunds Nakke. Aborrebjerg is the highest point of Møn and was formed during two separate events: A: Superimposed thrust fault deformation by the Young Baltic Ice Advance from the south (F1). B: Superimposed faulting by the latest ice advance from southern Sweden (F2). 


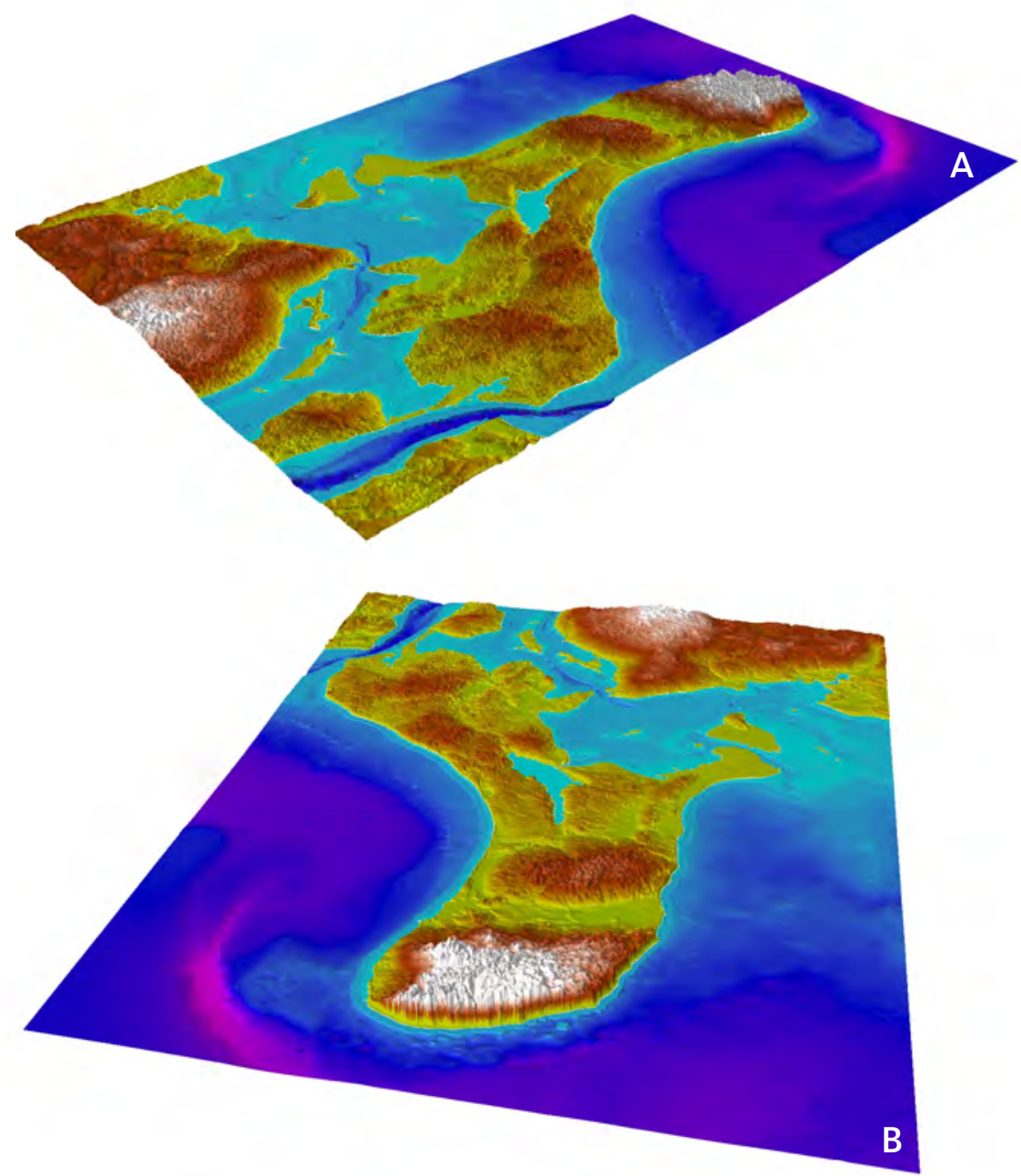

Fig. 44 Geomorfologiske højdemodeller af Møn. A: Møn set mod nord. B: Møn set mod vest. Gul-grøn: 0-25 m o.h. Brun: 25-50 m o.h. Hvid: højder over $50 \mathrm{~m}$ o.h.

Fig. 44. Geomorphological elevation model of Møn. A: Viewed towards north. $B$ : Viewed towards west. Yellow-green: 0-25 $m$ a.s.l. Brown: 25-50 $m$ a.s.I. White: above $50 \mathrm{~m}$ a.s.l. overpræget og til en vis grad reorienteret de allerede anlagte rygge (Pedersen 2000). En Ø-V-gående orientering af bakkerygge genfindes i det glacialmorfologiske landskab omkring Stege Nor. Selve noret kan betragtes som et morfologisk element, der følger bakkeryggens retning. De steder, hvor landskabets højeste toppe rager op, tolkes som resultater af, at skiver af skrivekridtunderlaget her allerede var skubbet op fra nordøst.

\section{Moraneplateauer}

Omkring 70 \% af jordarterne på Møns overflade består af moræneler, som altovervejende kan henføres til Lolland Till Formationen. Bortset fra Store Klinteskov og enkelte andre højere bakkepartier kan denne landskabstype med et morænedække karakteriseres som et moræneplateau dannet af en bundmoræne, der giver landskabet en flad, udjævnet terrænform med spredte afløbsløse lavninger. De skyldes dødishuller efter bortsmeltede isskiver og isklumper, der har været indarbejdet og begravet i moræneleret under det Ungbaltiske eller tidligere isfremstød (Fig. 45).

Under dækmoræneleret ligger en enhed af smeltevandssand, Ny Borre Formationen. I landskabet træder dette sand frem i dalstrøg, som det tydeligt ses i dalene øst og vest for Stege Nor. Fra Stege Nor og sydvestover er sandet udbredt i lavningen omkring Damsholte og Røddinge Sø og i dalstrøget ud mod Fanefjord.

\section{Hatformede bakker og overpragede åse}

På den vestlige del af Møn forekommer en del bakker, som kan tolkes som hatformede bakker eller åse, der har været overskredet af senere isfremstød end dem, der oprindeligt var årsag til pro- og inglaciale aflejringer. De proglaciale smeltevandsaflejringers dannelsesdynamik og deres efterfølgende deformation langs randzonen af isen gennemgås i følgende afsnit. De inglaciale aflejringer er dannet i tunneldale under isen eller i store isdæmmede søer med vandspejl på højde med isoverfladen, men med kanter og bund gennem isen relateret til sprækkezoner $\mathrm{i}$ ismassen. Efter isens tilbagesmeltning står disse aflejringer frem i landskabet som sand- og grusbakker, der i den ældre geologiske litteratur omtales som hatformede bakker (Berthelsen 1980). Det er uvist, hvor mange af Vestmøns bakker der kan betragtes som hatformede bakker, men en af dem, Præstebjerg, har været genstand for grusgravning, og 


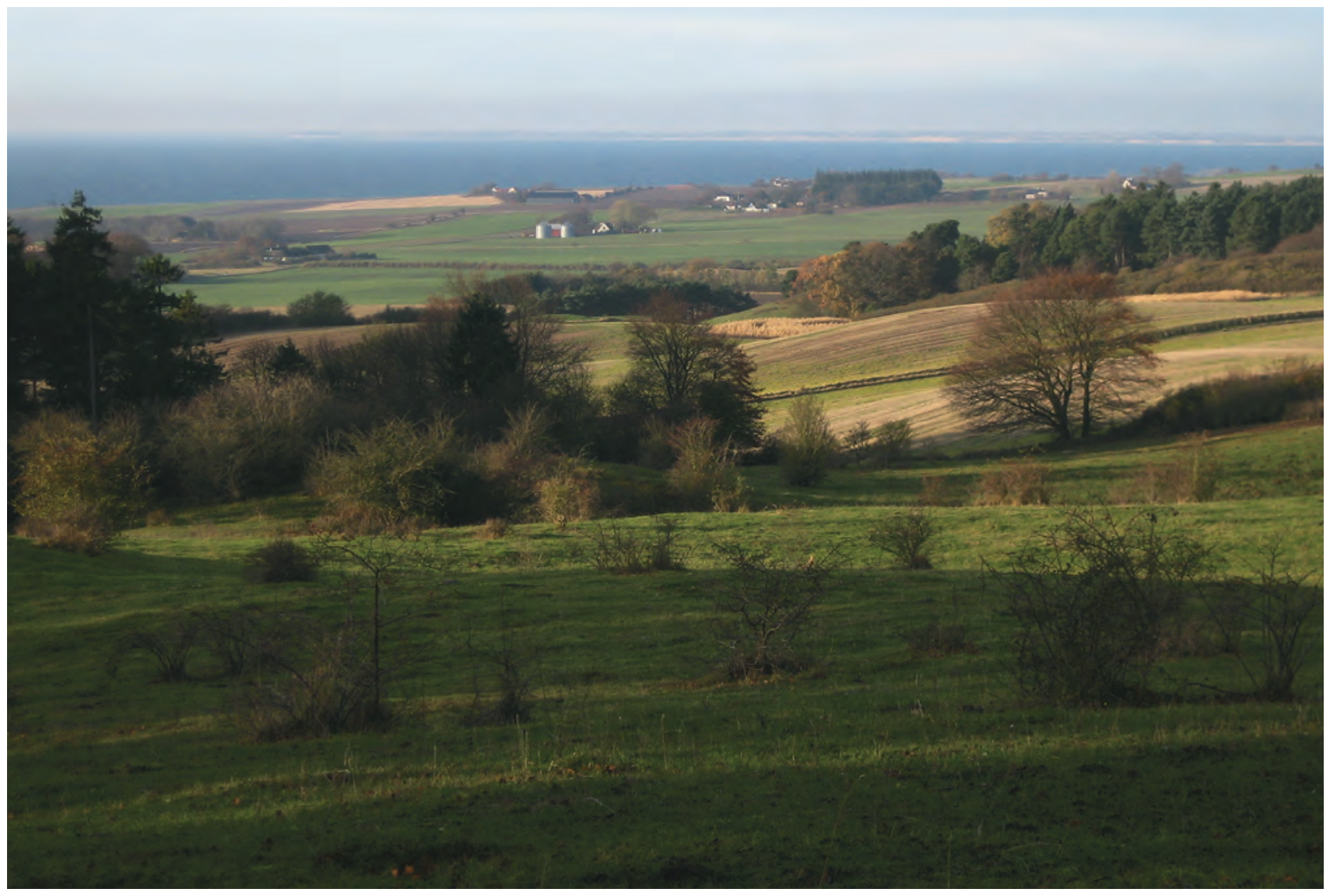

Fig. 45 Grænsen mellem det højtliggende landskab Høje Møn og det lavere småkuperede bundmorænelandskab set mod sydvest. I horisonten på den fjerne side af Hjelm Bugt anes de hvide klinter i Hvideklint.

Fig. 45. The boundary between the elevated landscape of Høje Møn and the landscape towards the west of the lower, undulating till plain. The white cliffs of Hvideklint can just be seen in the horizon on the far side of Hjelm Bugt.

under udvindingen af sand og grus kunne bakkens indre struktur studeres (Fig. 46; Berthelsen 1980).

Kriteriet for en hatformet bakke er, at den står frem som en isoleret hat i landskabet. Det er også en fordring, at lagene inde i bakken skal være deformerede og stejlt skråtstillede (denne fordring tilskrives Berthelsen (1980), som her har set bort fra talrige ikke dislocerede hatformede bakker f.eks. på Langeland). Berthelsens (1980) undersøgelse af Præstebjerg demonstrerer, hvor komplekse aflejrings- og deformationsprocesserne i en hatformet bakke kan være. I den første fase blev bakkens materiale aflejret som en proglacial smeltevandsslette, der efterfølgende blev foldet op af et isfremstød fra sydøst, antagelig Klintholm Isfremstødet (Fig. 47). Om dette isfremstød svarer til Ristinge Klint Till Formationens eller Klintholm Till Formationens is kan dog ikke endeligt afgøres uden en detaljeret OSL- eller infrared stimulated luminescence (IRSL)-aldersbestemmelse, men det er tydeligt, at lagserien er deformeret mod nordvest af en baltisk is. Den anden fase (fase $2 \mathrm{i}$ Fig. 47) er overskridelsen af Nordøstisen. Umiddelbart inden den Midtdanske Till Formations bundmoræne blev aflejret, blev sandbakken deformeret af et istryk fra nordøst mod sydvest. Den tredje fase blev indledt med, at bakkens nordlige side blev stærkt eroderet af en smeltevandsstrøm, som efterfølgende aflejrede en tyk serie smeltevandssand og -grus. Aflejringen skete foran et isfremstød fra øst, som efterfølgende overskred bakken og afsatte en tynd bundmoræne. I den afsluttende fjerde fase blev bakken overskredet af et nyt isfremstød fra sydøst, som foldede bakkens indre lag omkring en NØ-SV-strygende foldeakse og overkippede folderne mod NV (Fig. 47). I den her fremlagte tolkning foreslås, at de to sidste isfremstød var oscillerende isbevægelser, der kan relateres til den isstrøm, som aflejrede Lolland Till Formationen.

\section{Endemoraenelandskab med smeltevandsslette}

Fra Ny Borre og sydpå til Busemarke spreder sig en større akkumulation af smeltevandssand og -grus. I dette område har to af Møns største grusgrave også ligget, nemlig Ny Borre grusgrav og en grusgrav i den vestlige udkant af Busemarke. Området begrænses mod syd af randmorænebakkerne nord og syd for Råby Sø og 


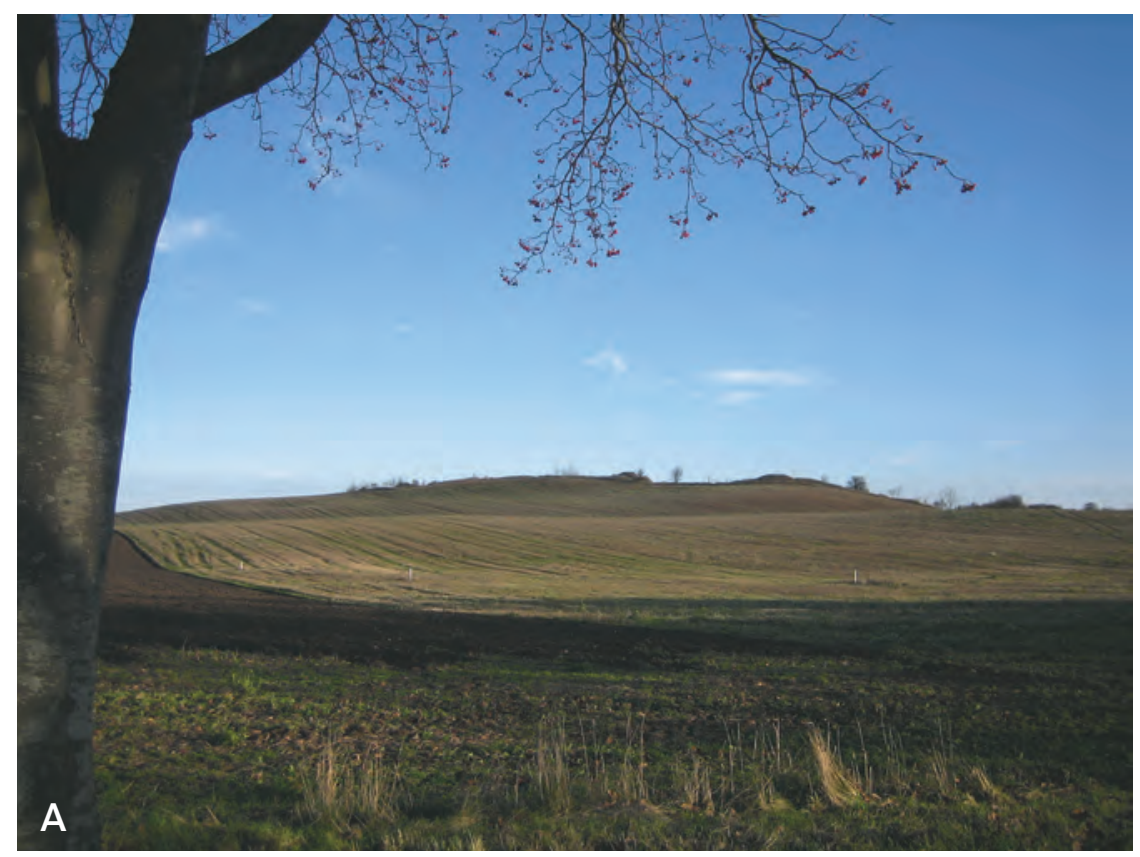

Fig. 46 Den hatformede bakke Præstebjerg på Vestmøn. A: Bakken set fra syd. Opgravet materiale ses på toppen. B: Stejltstillede lag af smeltevandssand og -grus inde $\mathrm{i}$ bakken. Disse lag skæres øverst og overlejres af moræneler tilhørende Lolland Till Formationen.

Fig. 46. The hat-formed hill of Proestebjerg on western Møn. A: The hill viewed from the south, with excavated material at its top. B: Vertical layers of meltwater sand and gravel inside the hill, cut and overlain by clayey till of the Lolland Till Formation.

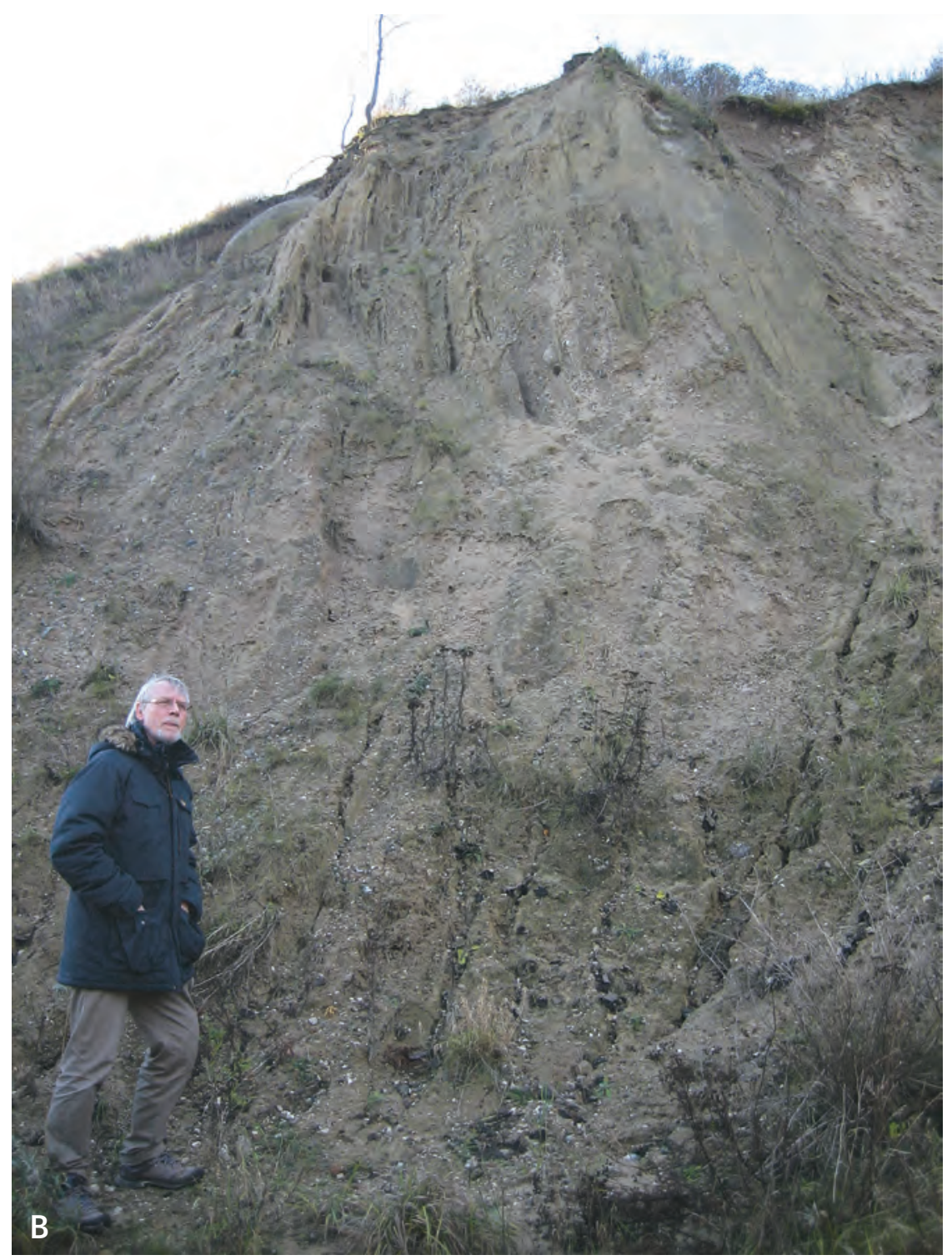




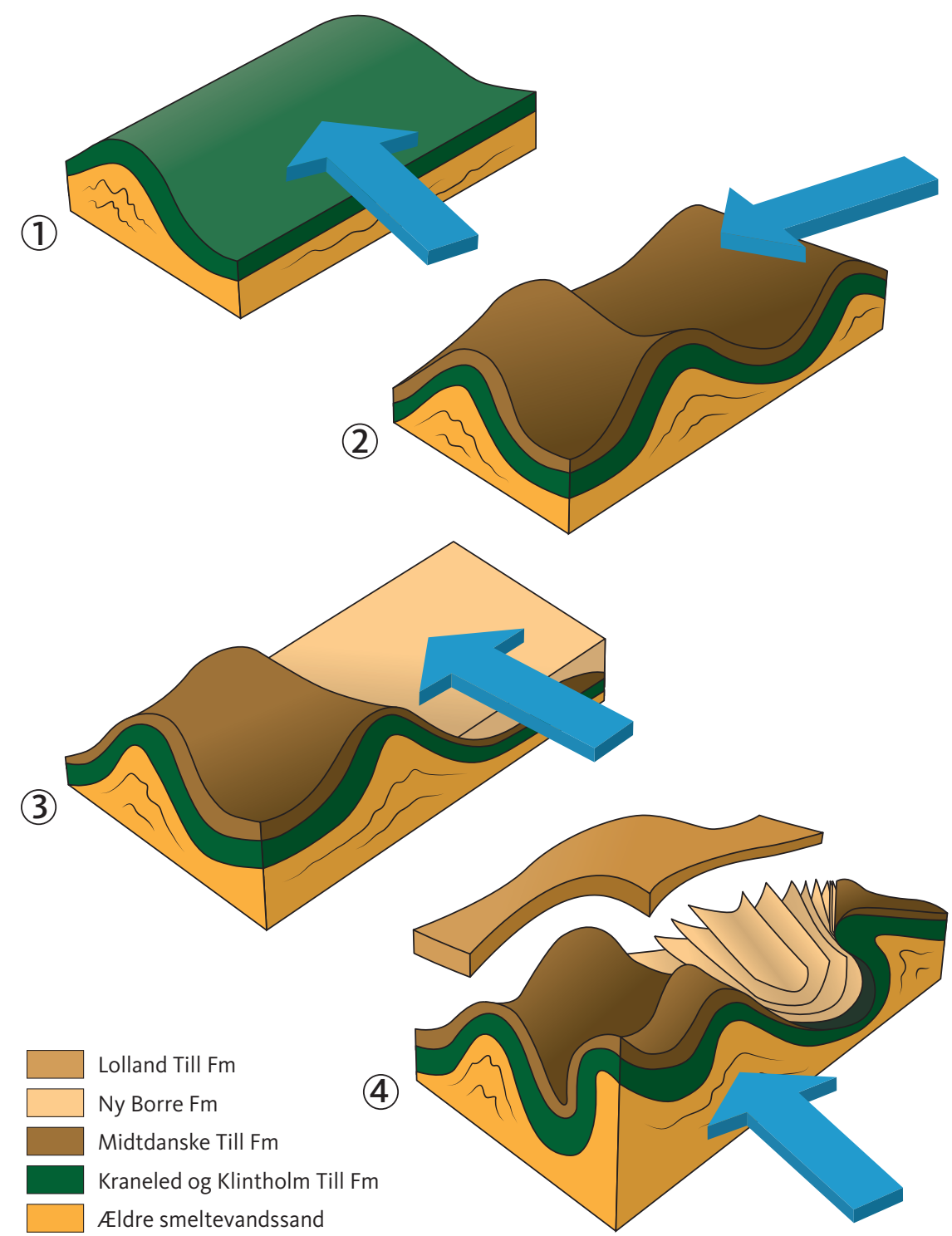

Fig. 47 Dannelsen af Præstebjerg. 1: Opfoldning af Kraneled og Klintholm Till Formationerne under Klintholm Isfremstødet fra øst-sydøst. 2: Genfoldning og aflejring af den Midtdanske Till Formation under $\mathrm{N} \varnothing$-Isfremstødet fra nordøst. 3: Smeltevandserosion fra en østlig retning og aflejring af Ny Borre Formationen. 4: Genfoldning under det Ungbaltiske Isfremstød fra sydøst og aflejring af Lolland Till Formationen. Delvis efter Berthelsen (1979).

Fig. 47. Model for the formation of Proestebjerg. 1: Folding of the Kraneled and Klintholm Till Formations during the Klintholm Ice advance from east-southeast. 2: Superimposed folding and deposition of the Mid Danish Till Formation by the NE Ice advance from northeast. 3: Glaciofluvial erosion by meltwater streams moving from east to west and deposition of the Ny Borre Formation. 4: Superimposed deformation due to the Young Baltic Ice advance from south-east and deposition of the Lolland Till Formation. Partly from Berthelsen (1979).
Busemarke Mose med den mest markante bakketop ved Kobbelgård. Disse bakker udgør et endemorænelandskab sammen med de øvrige bakkestrøg, der stryger parallelt med kysten ud mod Hjelm Bugt. Foran randmorænebakkerne spredte sig en smeltevandsslette fra Busemarke til Ny Borre, hvorfra afstømningen af smeltevand videre nordpå fremeroderede den brede Borre Sømose lavning. Det amerikanske udtryk for et landskab skabt af smeltevandsafstrømning er 'spillway'. Dalstrøget op mod Maglemose kan betragtes som en lignende dannelse. Også lavningen fra nordkysten ind mod Borre Sømose og Maglemose lavningen tjente som 'spillways' for smeltevandet, da isranden under tilbagesmeltningen havde en kortvarig stilstand ved kysten af Hjelm Bugt. Smeltevandet løb da især gennem dalstrøget mod Maglemose, hvor sand og grus blev omlejret under den senglaciale afsmeltning. En lignende dannelseshistorie har også betinget udviklingen af områderne ved Stege
Nors udmunding mod Stege Bugt, Klostervig, Røddinge Sø og Fanefjord. I alt udgør arealer med smeltevandssand knap $10 \%$ af jordarterne i Møns overflade.

Da den Ungbaltiske Is endelig smeltede tilbage fra Møn, fremstod øen som et randmorænelandskab. Hjelm Bugt udgør et lobeformet bækken, der kan betragtes som den lavning, hvorfra materialet til opbygningen af Møn stammer.

\section{Det marine forland med strandvolde og krumodder}

For ca. 8000 år siden blev de indre danske farvande oversvømmet af den Atlantiske Transgression. Denne havstigning beløb sig til mere end $20 \mathrm{~m}$, og dens marine aflejringer findes nu i lavtliggende kystområder. De udgør ca. 10 \% af jordarterne på Møn. Borre Sømose og Maglemose blev på dette tidspunkt omdannet til fjorde, og Klostervig udgjorde et smalt stræde mellem nogle 


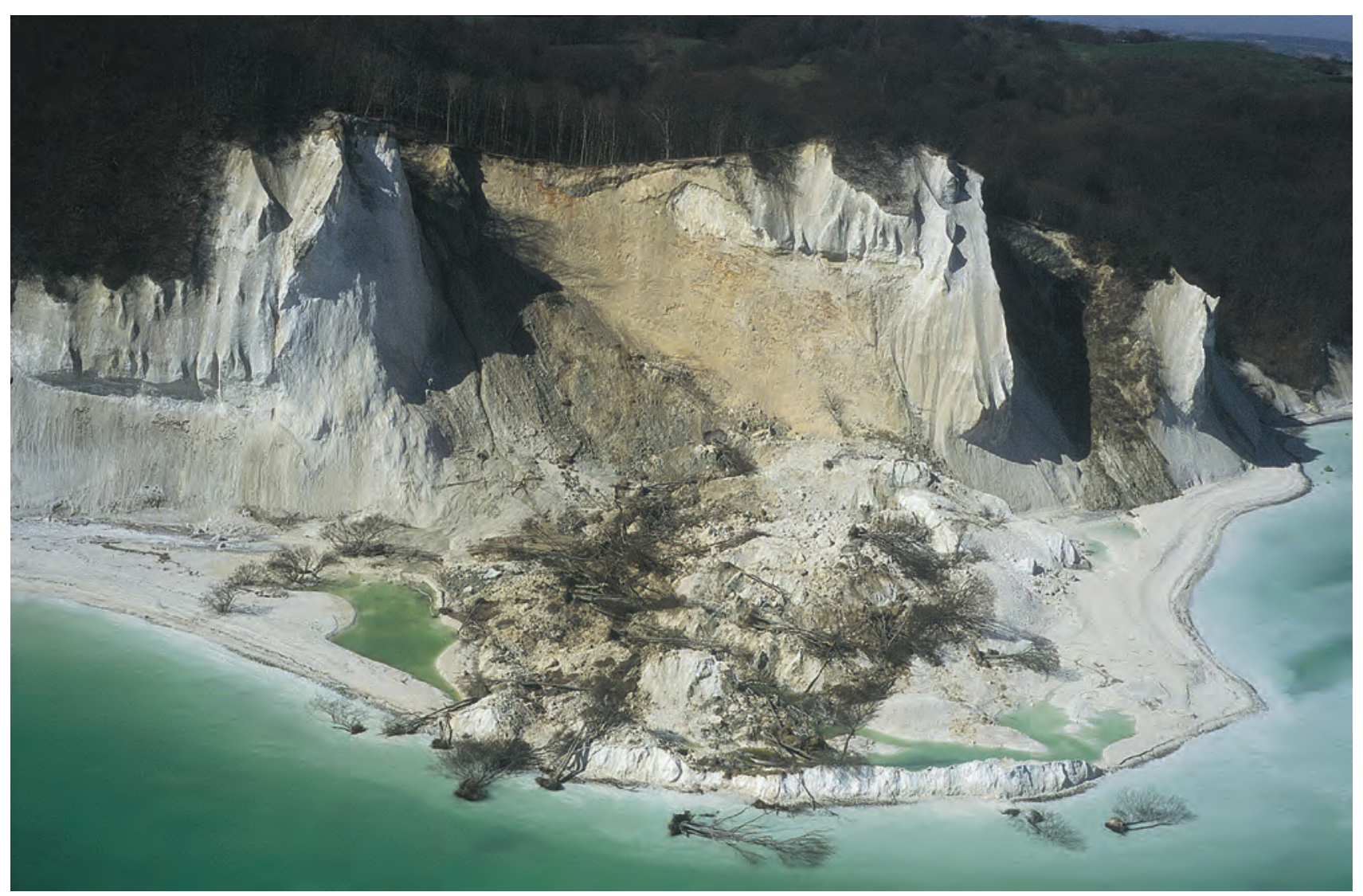

Fig. 48 Fjeldskred ved Store Taler i januar 2007. Flyfoto.

Fig. 48. Landslide at Store Taler in January 2007. Aerial photograph.

småøer og holme. På grund af materialestrømmen langs kysten blev disse fjorde og stræder lukket, efterhånden som strandvolde spærrede for havvandets indtrængen. Bag strandvoldene dannedes strandsøer, som efterfølgende groede til og blev til moser med tykke lag af tørv.

Mest markant blev udviklingen af det marine forland, hvor havstrømmenes materialetransport udbyggede kystområderne. På denne måde blev Ulvshale skabt. Kortlægningen af strandvolde, der danner krumodder, viser tydeligt en transportretning langs nordkysten af Møn fra øst mod vest. Ved Møns nordspids blev det marine forland udbygget mod nordvest, hvor strandvoldene danner markante rygge, der hyppigt overlejres af en mindre klit. Også et mindre område ud for Hårbølle Havn er dannet som et marint forland. Her viser mønsteret af strandvolde, at der blev dannet et vinkelforland, idet transporten skete fra to modsatte retninger. Hårbølle forlandet er således både udbygget ved sydgående transport gennem Grønsund og ved nordvestgående transport fra Hjelm Bugt gennem Grønsund. Transporten af materiale frem til Møns nordvestlige og sydvestlige hjørner viser tydeligt, at kildeområdet skal findes på Møns østside. Her er det naturligvis de høje klinter langs Møns Klint, der har bidraget med erosionsmateriale, specielt fra de mange fjeld- og jordskred, som beskrives nedenfor.

\section{Fjeldskred og jordskred}

Fjeldskred forekommer kun få steder i Danmark. Møns Klint er det mest markante område på grund af de høje, stejle skrivekridtklinter (Pedersen et al. 1989; Nadim et al. 2008; Pedersen \& Gravesen 2009; Pedersen 2012b). En anden skredtype er jordskred, som også forekommer hyppigt på Møns Klint og mange andre steder i landet (Nadim et al. 2008). Forskellen på de to skredtyper er litologi og terrænstejlhed. Fjeldskred opstår, hvor en blok af en helt eller delvis konsolideret bjergart skrider ned fra en stejl klippeside ved et næsten lodret fald, på engelsk betegnet 'rockfall'. Jordskred opstår, hvor de geologiske lag består af vandmættede leraflejringer, og hvor skråningens gradient kun behøver at være nogle få grader. På grund af et højt porevandstryk bliver jordlagene båret af en mudderfilm og bevæger sig med langsom til moderat hastighed ned ad det skrånende terræn. Denne skredtype, som dækker et spektrum fra mudderstrømme til terrasseformede blokudskridninger, betegnes på engelsk under ét som 'landslides'. 


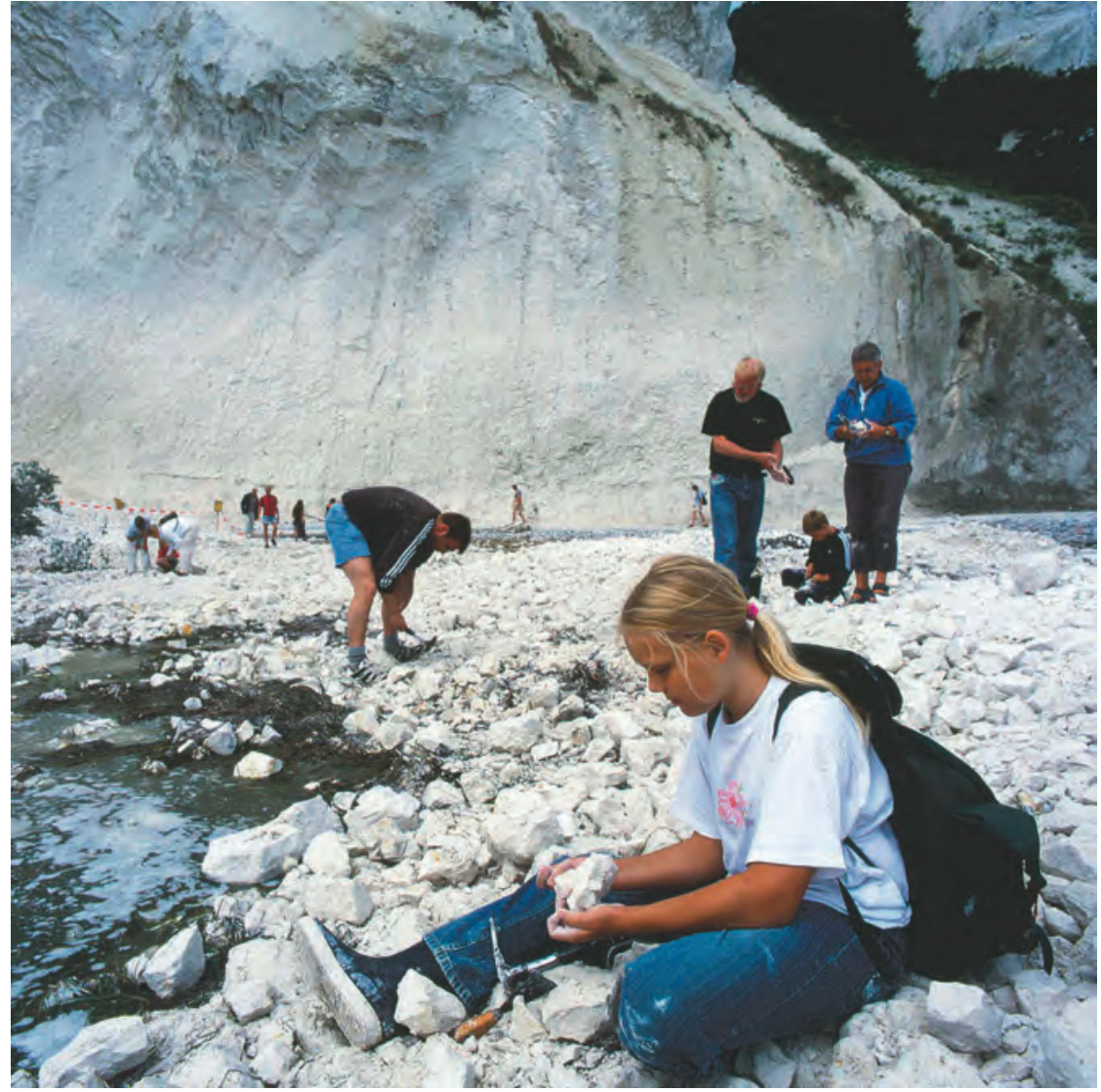

Fig. 49 Efter fjeldskred i klinten er fossiljagt meget populært i det nedskredne skrivekridt. Foto: Peter Moors.

Fig. 49. After rockfalls from the cliffs, fossil hunting in the displaced chalk material is very popular. Photo: Peter Moors.

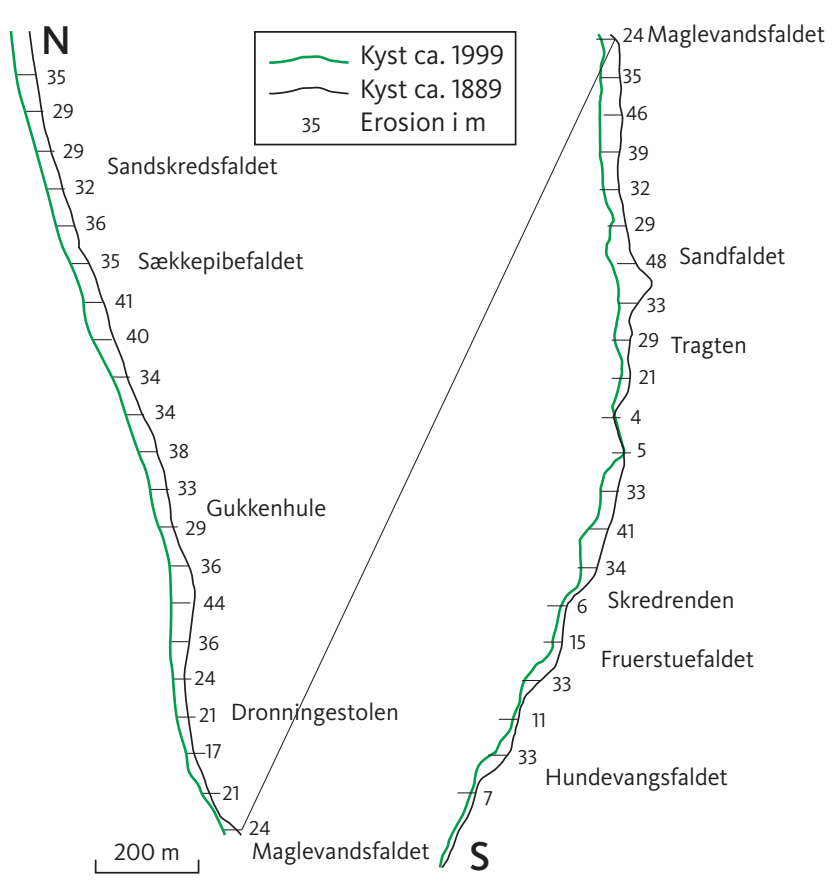

Fig. 50 Erosion og tilbagetrækning af Møns Klint over tid på grund af skred og erosion, vist ved forskellen mellem kystens beliggenhed i 1899 og ca. 1999.

Fig. 50. Erosion and retreat of Møns Klint over time by landslides and erosion, shown as the calculated difference between the coastlines in 1899 and c. 1999.

\section{Fjeldskred}

Der er inden for de seneste 100 år kun rapporteret et enkelt tilfælde, hvor et dansk fjeldskred har medført et dødsoffer. Det indtraf den 29. juli 1994 fra Maglevandsnakke lige syd for Dronningestolen (Pedersen 1994). Skreddet var usædvanligt ved at foregå midt på en tør sommerdag. Den blok, som faldt ned, var kun på nogle få tusind kubikmeter (2500-3000 m³, Pedersen 1994), men da faldet skete på et tidspunkt, hvor talrige turister færdedes på stranden, var risikoen for et fatalt uheld stor. En person blev dræbt under skreddet, og siden har klinten på det pågældende sted været genstand for omhyggelig overvågning. Imidlertid er det vanskeligt at forudse, hvor et kommende fjeldskred vil ske. En registrering af de seneste 50 års fjeldskred har vist tegn på, at et større skred forekommer omkring hvert femte år (Tabel 1). Det seneste større skred, hvor $100000 \mathrm{~m}^{3}$ materiale spredte sig $300 \mathrm{~m}$ ud fra kysten, indtraf i januar 2007 ved fjeldpartiet Taleren (Fig. 48; Pedersen 2007). Samme år skete der flere andre skred langs Møns Klint og andre steder i landet. Årsagen til disse skred var et ualmindelig regnfuldt efterår, hvor den gennemsnitlige grundvandsstand stod ca. $1 \mathrm{~m}$ over normalvandstanden. Derfor var porevandstrykket meget højt i de øverste jordlag, hvilket betød, at brudstyrken var sænket. Med nedsat brudstyrke er 


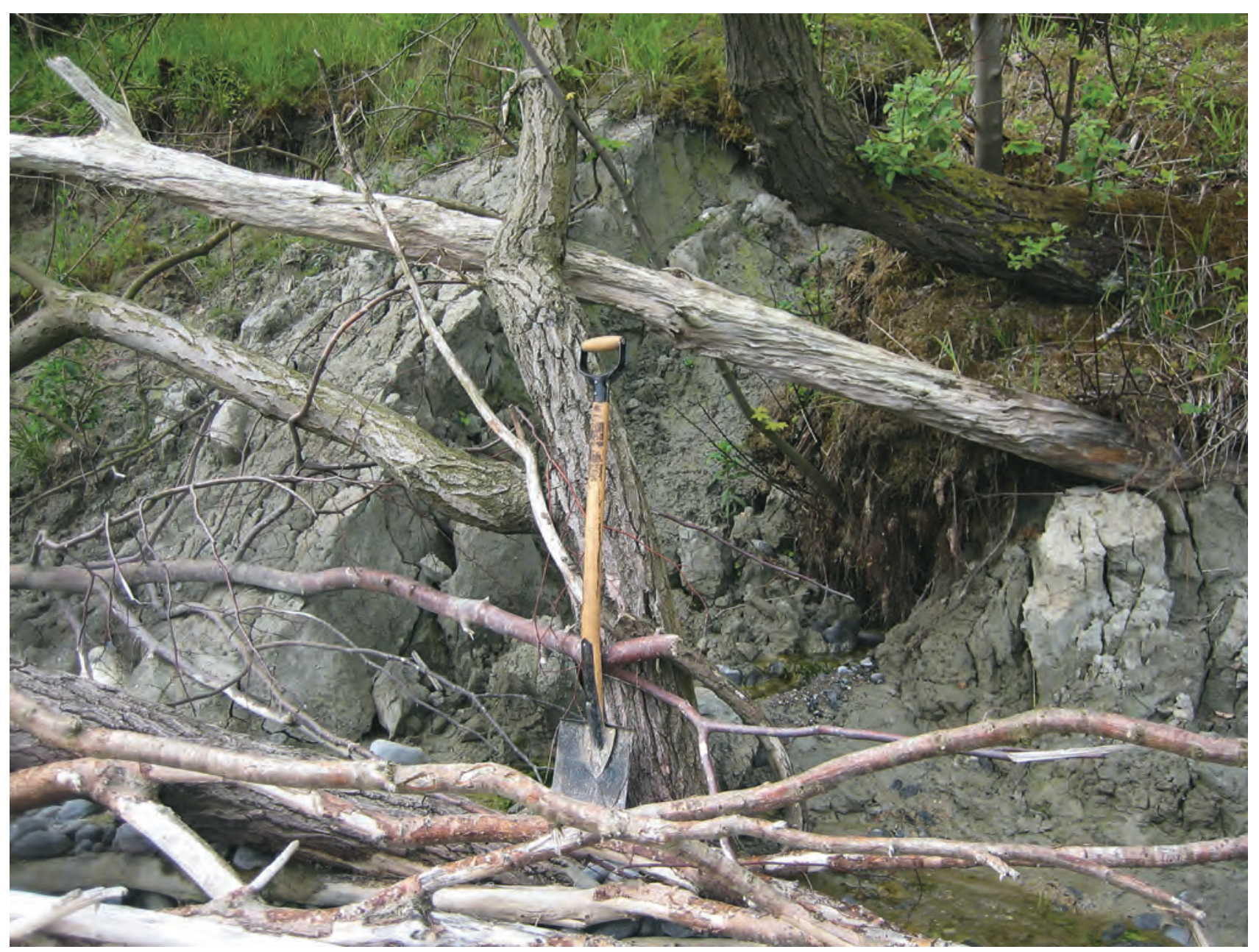

Fig. 51 Jordskred på stranden neden for Liselund Slot med ler fra Kobbelgård Formationen og nedstyrtede træer.

Fig. 51. Landslide on the beach below Liselund Castle with clay from the Kobbelgård Formation and fallen trees.

tilbøjeligheden til sprækkedannelse større, og når der først er dannet sprækker, er grundlaget for en udskridning skabt.

Hver gang et større fjeldskred er sket, er der dannet en halvø af skrivekridt (Fig. 49). De friske klumper af skrivekridt er et yndet mål for fossiljægere. Normalt afspærres området lige neden for fjeldskredfladen, da efterskred på et par kubikmeters størrelse hyppigt sker op til et par døgn efter et stort kollaps.

En opgørelse af erosionsraten kan give et overordnet udtryk for skredforholdene. Ved at sammenligne kystlinjen langs klinten fra 1899 med kystlinjen opmålt 100 år senere får man et godt billede af erosionsraten forskellige steder langs kysten (Fig. 50). Den gennemsnitlige erosionsrate er knap 30 cm om året, hvilket er omkring dobbelt så meget som den almindelige erosion langs andre danske klintkyster. De steder, hvor erosionsraten er højest, 44-49 $\mathrm{cm} / a ̊ r$, er dog ikke ud for de stejle skrivekridtprofiler, men derimod ud for de store fald mellem stejlklinterne. Således er Sandfaldet mellem Sommerspirklinten og Græderen syd for Dronningestolen et udsat sted, idet der forekommer et kildevæld, og sandmasserne er relativt løse med stor tendens til vedvarende sandskred.

\section{Jordskred}

Jordskred, hvor lerrige klinter skrider ud, forekommer almindeligt langs de fleste danske klintkyster. På Møn er det især den nordlige del af Møns Klint, der er udsat for denne skredtype. De største kendte skred skete i forrige århundrede, først i 1905 efter en større stormflod i østersøområdet, hvor omkring 4 ha af Liselunds parkområde skred ud i Østersøen. Femten år senere blev jordskreddene ved Liselund igen aktiveret, dog kun med skred på den halve størrelse, og i 1927 var der igen aktive udskridninger samme sted. Endnu i dag kan man se terrassemorfologi og slugter, som skyldes de tidligere jordskred (Hintze 1904, 1920). Ved foden af Liselunds kystskrænt ser man årsagen til de mange jordskred. Her træder det blågrå issøler fra Kobbelgård Formationen frem i strandplanet. Det er på dette blågrå ler, at 
Table 1 Større fjeldskred og jordskred ved Møns Klint mellem 1801 og $2015^{\S}$

\begin{tabular}{|c|c|c|c|c|}
\hline Årstal & Dato & Lokalitet & Størrelse & Klasse $^{\dagger}$ \\
\hline 1801 & & Ved Taleren & & \\
\hline 1868 & $24 / 12$ & Dele af Dronningestolen & $3000000 \mathrm{~m}^{3}$ & 3 \\
\hline 1899 & & Sækkepibe Fald & $100000 \mathrm{~m}^{3}$ & 3 \\
\hline 1904 & $31 / 12$ & Nord for Sommerspiret og ved Gukkende Hule & & \\
\hline 1905 & $05 / 11$ & Liselund Lerskred & 4 ha & 3 \\
\hline 1910 & $13 / 03$ & Hundefangsklinten & & \\
\hline 1914 & Nytårsnat & Ved Dronningestolen og Forchhammers Pynt & & \\
\hline 1920 & $14 / 09$ & Liselund, lerskred & 4 tdr. land & 3 \\
\hline 1927 & $05 / 11$ & Større skred ved Liselund & & \\
\hline 1927 & $22 / 11$ & Slotsgavlene, Pomlerende, Nonnebænken, Stubberup Have & & \\
\hline 1928 & $11 / 05$ & Hundefangsfaldet & $20-30 \mathrm{tdr}$ land & 3 \\
\hline 1929 & & Sydlige del af Dronningestolen & & \\
\hline 1939 & $25 / 01$ & Puggaards Pynt & 2-300 m halvø & 3 \\
\hline $1940-46$ & & Gukkende Hule, del af Vidmunds Nakke, Forchhammers Pynt & & \\
\hline 1948 & $15 / 01$ & Dronningestolen & & \\
\hline 1952 & $24 / 01$ & Røde Udfald med dele af Vitmunds Nakke og Puggaards Klint & halvø $500 \mathrm{~m}$ & 3 \\
\hline 1958 & & Vitmunds Nakke & & \\
\hline 1963 & & Maglevandsfaldet & & \\
\hline 1970 & & Store Stejlebjerg & & 2 \\
\hline 1979 & & Gavl af Sommerspiret & & 2 \\
\hline 1980 & & Hylledalsfald & & 1 \\
\hline 1988 & $13 / 01$ & Sommerspiret & & 1 \\
\hline 1994 & $29 / 07$ & Sydlige del Dronningestolen. Fransk turist dræbt kl. 12:30 & $3000 \mathrm{~m}^{3}$ & 1 \\
\hline 1998 & $04 / 03$ & Freuchens Pynt, $100 \mathrm{~m}$ ud i havet & & 3 \\
\hline 2003 & 05/07 & Store Stejlbjerg, kl. 8:50 & $12000 \mathrm{~m}^{3}$ & 2 \\
\hline 2004 & $16 / 01$ & Nordlige del af Jættebrinken, kl. 16 & $4000 \mathrm{~m}^{3}$ & 2 \\
\hline 2004 & $17 / 03$ & Sommerspirpynt & $2000 \mathrm{~m}^{3}$ & 2 \\
\hline 2007 & $27 / 01$ & Store Taler. Nat & $100250 \mathrm{~m}^{3}$, halvø $300 \mathrm{~m}$ & 3 \\
\hline 2007 & $02 / 03$ & Freuchens Pynt, formiddag & $25000 \mathrm{~m}^{3}$, halvø $150 \mathrm{~m}$ & 3 \\
\hline 2007 & $30 / 09$ & Abildgaards Fald, nat. Lerskred, skredtå, strandbred løftet 6 m op & & 2 \\
\hline 2009 & $15 / 10$ & $\begin{array}{l}\text { Nylands Nakke, nat. Tør sensommer slår om til nattefrost. Over- } \\
\text { hæng fjeldskred }\end{array}$ & $5000 \mathrm{~m}^{3}$ & 1 \\
\hline 2015 & $05 / 12$ & Græderen faldet efter orkanen Bodil & & 1 \\
\hline
\end{tabular}

${ }^{\S}$ Tabellen omfatter både fjeldskred af skrivekridt og nedskredet kvartært materiale.

Landslides along Møns Klint between 1801 and 2015. Comprises both rockfalls of Cretaceous chalk and landslides of Quaternary deposits.

${ }^{\dagger}$ 1: Mindre. 2: Middel. 3: Stort.

hele udskridningen foregår. Skreddene er stadig aktive, hvilket ses af de mange væltede træer, som ligger på stranden, der er domineret af flintrigt grus og sten (Fig. 51). Ikke kun ved Liselund forårsager leret fra Kobbelgård Formationen jordskred. I efteråret 2007 skete der en cylindrisk udskridning ved Abildgaards Fald, hvorved hele strandplanet ved foden af skreddet blev løftet $6 \mathrm{~m}$ op over havoverfladen (Fig. 52). Hele kystklinten længere nordpå fra Liselund via Hellehavn Nakke til Pomlerende er domineret af jordskred, der forskyder de kvartære lagserier, som karakteriserer Møns Klints nordlige del.

\section{English summary}

The geological map sheet Møn covers the island of Møn, the smaller neighbouring islands Langø, Lindholm and Nyord, and adjacent parts of Sjælland and Lolland. It comprises the geodetic map sheets 1511 I and 1511 II and areas on bordering sheets. Møn is surrounded by the Baltic Sea with the bay of Hjelm Bugt to the south, the straits of Grønsund and Ulvsund to the west, and the bays of Stege Bugt and Fakse Bugt to the north.

Møn is divided into three geomorphological areas, namely the high, hilly landscape of Høje Møn to the east, the hummocky to parallel ridge landscape to the west and the areas of marine deposits around Nyord and Ulvshale. The composite ridge landscape of Høje Møn constitutes a glacial tectonic complex comprising four individual glacial dynamic sequences, with the hill Aborrebjerg as the highest point (143 $\mathrm{m}$ a.s.l.). The parallel ridge hills consist of thrust-fault-displaced chalk sheets with superimposed glacial deposits. The thrust sheets are up to $80 \mathrm{~m}$ thick, of which $60 \mathrm{~m}$ constitute Maastrichtian chalk. The vertical displacement of the thrust sheets is about $150 \mathrm{~m}$ measured from the primary, undeformed pre-Quaternary surface located 25-30 m below sea level. The pre-Quaternary surface 


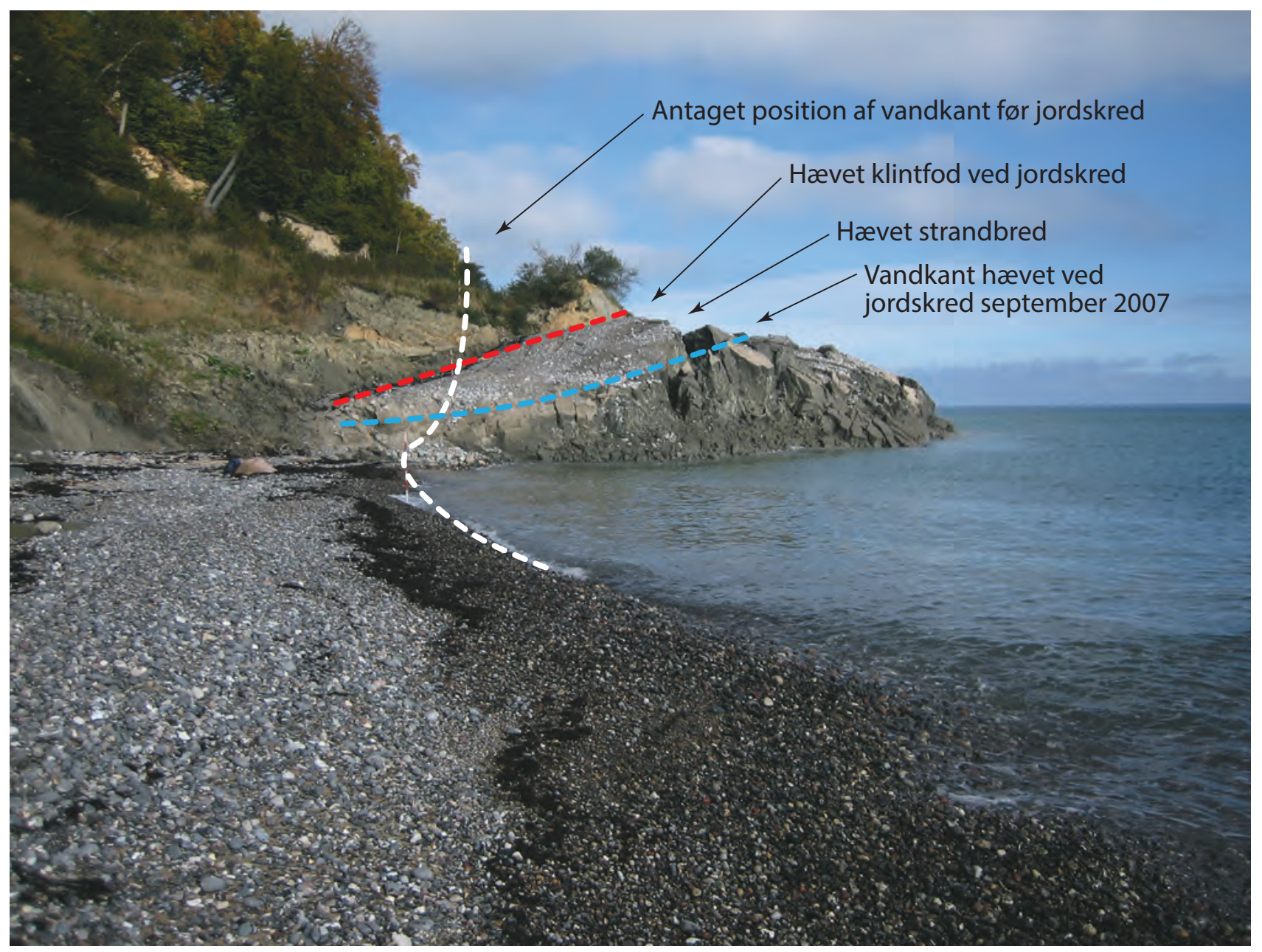

Fig. 52 Jordskred ved Abildgaards Fald i den nordlige del af Møns Klint, september 2007. De tre linjer viser jordskreddets front, hævede strandvolde og den nuværende strandbred med antaget forlængelse.

Fig. 52. Landslide at Abildgaards Fald in northern part of Møns Klint in September 2007. The toe of the slide displaced the beach plane. The three lines mark the elevated cliff foot, the elevated former shoreline and its recent position with an extrapolation.

consists of chalk of Late Maastrichtian age, which forms a carbonate platform in the subsurface of Møn about 27 $\mathrm{m}$ below sea level. Chalk displaced by glacial tectonics is not restricted to Høje Møn but also appears in smaller thrust sheets and rafts in the small-ridged landscape around Stege Nor. In the chalk sheets along Møns Klint most of the Late Maastrichtian succession is exposed. Cliff sections with chalk are also exposed at Hvideklint along the south coast of the island. However, here the glacial tectonic shear deformation has commonly altered the lithology into a chalk glacitectonite.

The oldest Quaternary units deposited on the pre-Quaternary unconformity are Saalian till as well as sand and clay from the Eemian Interglacial. These units are overlain by Early Weichselian sand. The next Quaternary succession, the Ristinge Klint Till Formation, was deposited during the Ristinge ice advance in the early Middle Weichselian about 55 000-50 000 years ago. Then followed the Kraneled Formation (new formation) consisting of fluvial and lacustrine deposits. The following Klintholm Till Formation (adjusted formation) was deposited during the Klintholm ice advance 35000 32000 years ago. The Klintholm Till Formation is overlain by a more than $10 \mathrm{~m}$ thick unit of greyish glaciolacustrine clay with dropstones. Glaciofluvial sand with thin-layered intercalations of laminated mud and diamictites of the Kobbelgård Formation (new formation) are related to this unit and interpreted as deposited in a huge, partly ice dammed lake covering a large part of the present Baltic Sea and the southern part of Kattegat 32000 to 28000 years ago. The Kobbelgård Formation is overlain by sand and gravel of the Stubberup Have Formation (new formation) and tills of the Mid Danish Till Formation deposited by the advance of Nordøstisen (the North-East Ice) from central Sweden about 23 000-20 000 years ago.

Relatively shortly after the NE-ice had melted away, the Ungbaltiske Is (Young Baltic Ice) advanced from the eastern part of the Baltic area. North-directed 
compressive deformation during his advance created the glacial-tectonic complex of Møns Klint including the new unit 'Møns Klint Glacialdynamiske Sekvens'. In the southern part of the complex, a steeply inclined imbricated fan was formed; towards the foreland to the north the thrust faults became gently dipping and the tip-zone of thrusting is located under the landslides at Liselund. The composite ridges form a characteristic hilly landscape with elongate crests trending $\mathrm{E}-\mathrm{W}$.

The curved coastline along Hjelm Bugt was formed by a glacial lobe, north of which a push moraine was built up. A number of spillways striking radially northward from the lobe were formed by meltwater discharged from its glacier ports, including the Borre, Maglemose and Røddinge depressions. Deposition of sand and gravel of the Ny Borre Formation (new formation) took place at this time. During the advance of the Young Baltic Ice over southern Denmark to the Eastern Jutland stationary line, a relatively thin lodgement till of the Lolland Till Formation was deposited, which is rich in chalk due to its truncation of the upthrusted chalk sheets.

Towards the end of the Weichselian glaciation $c$. 17000 years ago, the Young Baltic Ice melted back, leaving a residual ice cap in Skåne from where a recessive ice advance towards south-west reached Møns Klint, resulting in superimposed glacial tectonic deformation.

During the Late Weichselian, freshwater lakes in the Hjelm, Tøvelde and Høje Møn areas were filled by clay and gyttja, with deposition that continued into the Holocene.

During the Holocene, the former spillways were turned into fjords during the Atlantic transgression. Marine deposits mirroring the Littorina Sea are thus found in Maglemose and Borre Sømose. After the Atlantic transgression had established a sea level more or less corresponding to that of the today, accretion of marine forelands and formation of a spit system started. In particular, this is the case for the areas of Ulvshale and Nyord. At the same time vegetation migrated out into the numerous fjords, and peat began to accumulate. The last phase of sedimentation is confined to the formation of beach ridges in the coastal areas, typically covered by aeolian dunes, as can be seen on the coast at Klintholm Havn and Råbylille as well as along the north-eastern coast of Ulvshale.

\section{Tak}

En stor tak skal rettes til Tove Stockmarr og Gerald Hyde for tilladelse til at anvende deres specialeopgaver, herunder figurer og fotos. Gunver Krarup Pedersen takkes for mange konstruktive faglige kommentarer til en tidligere version af teksten. De to eksterne bedømmere Helena Alexanderson og Nikolaj Krogh Larsen takkes for omhyggelig gennemgang af teksten og forslag til forbedringer. Ansvaret for det geologiske kort og den endelige tekst er forfatternes.

\section{Additional information}

Funding

Funded by GEUS.

Additional files

The Møn geological map sheet is supplied as an additional file at https://doi.org/10.22008/FK2/TMFH5W

\section{References}

Aaris-Sørensen, K., Petersen, K.S. \& Tauber, H. 1990: Danish finds of mammoth (Mammuthus primigenius (Blumenbach)): Stratigraphical position, dating and evidence of Late Pleistocene environment. Danmarks Geologiske Undersøgelse Serie B 14, 44 sider. https://doi. org/10.34194/serieb.v14.7081

Aber, J. 1979: Kineto-stratigraphy at Hvideklint, Møn, Denmark and its regional significance. Bulletin of the Geological Society of Denmark 28, 81-93.

Aber, J.S., Croot, D. \& Fenton, M.M. (red.) 1989: Glaciotectonic Landforms and Structures. Glaciology and Quaternary Geology Series 5. Amsterdam: Kluwer Academic Publishers, 201 sider.

Andersen, S.A. 1936: Submarine Strandvolde i Faxe Bugt. Meddelelser fra Dansk Geologisk Forening 9, 85-88.

Andersen S.A. 1945: Isstrømmenes retning over Danmark i den sidste Istid, belyst ved ledeblokundersøgelser. Meddelelser fra Dansk Geologisk Forening 10, 594-615.

Anjar, J., Larsen, N.K., Björck, S., Adrielsson, L. \& Filipsson, H. 2010: MIS 3 marineand lacustrinesediments atKriegersFlak, southwesternBaltic Sea. Boreas 39, 360-366. https://doi.org/10.1111/j.1502-3885.2010.00139.x

Anjar, J., Adrielsson, L., Bennike, O., Björck, S., Filipsson, H.L., Groeneveld, J., Knudsen, K.L., Larsen, N.K. \& Möller, P. 2012: Palaeoenvironments in the southern Baltic Sea Basin during Marine Isotope Stage 3: a multi-proxy reconstruction. Quaternary Science Reviews 34, 81-92. https://doi.org/10.1016/j.quascirev.2011.12.009

Banham, P. 1977: Glacitectonites in till stratigraphy. Boreas 6, 101-105. https://doi.org/10.1111/j.1502-3885.1977.tb00339.x

Bennike, O. \& Jensen, J.B. 1995: Near-shore Baltic Ice Lake deposits in Fakse Bugt, southeast Denmark. Boreas 24, 185-195. https://doi. org/10.1111/j.1502-3885.1995.tb00772.x

Bennike, O., Houmark-Nielsen, M., Böcker, J. \& Heiberg, E.O. 1994: A multi-disciplinary macrofossil study of Middle Weichselian sediments at Kobbelgård, Møn, Denmark. Palaeogeography, Palaeoclimatology, Palaeoecology 111,1-15. https://doi.org/10.1016/0031-0182(94)90344-1

Bennike, O., Houmark-Nielsen, M. \& Wiberg-Larsen, P. 2007: A Middle Weichselian interstadial lake deposits on Sejerø, Denmark: macrofossil studies and dating. Journal of Quaternary Science 22, 647-651. https://doi.org/10.1002/jqs.1084

Berglund, B.E., Håkansson, S. \& Lagerlund, E. 1976: Radiocarbon-dated mammoth (Mammuthus primigenius Blumenbach) finds in South Sweden. Boreas 5, 177-191. https://doi.org/10.1111/j.1502-3885.1976. tb00261.x

Berthelsen, A. 1973: Weichselian ice advances and drift successions in Denmark. Bulletin of the Geological Institutes of the University of Uppsala 5, 21-29.

Berthelsen, A. 1979: Recumbent folds and boudinage structures formed by subglacial shear: an example of gravity tectonics. Geologie en Mijnbouw 58, 253-260.

Berthelsen, A. 1980: En Hatformet Bakke. Varv 3, 82-88.

Berthelsen, A., Konradi, P. \& Petersen, K.S. 1977: Kvartære lagfølger og strukturer i Vestmøns klinter. Dansk Geologisk Forenings Årsskrift for 1976, 93-99.

Cohen, K.M. \& Gibbard, P.L. 2012: Regional chronostratigraphical correlation table for the last 270,000 years: North Atlantic - Greenland - West, North, East, Central Europe - Russia. Abstract INTIMATE Workshop Utrecht, Netherlands, March 2012

Damholt, T. \& Surlyk, F. 2012: Nomination of Stevns Klint for inclusion in the World Heritage List, 160 sider. Kulturarvsstyrelsen, Stevns Kommune og Østsjællands Kommune. 
Ehlers, J., Eissmann, L., Lippstreu, L., Stephan, H.-J. \& Wansa, S. 2004: Pleistocene glaciations of North Germany. I: Ehlers, J. \& Gibbard, P.L. (red.): Quaternary glaciations - extent and chronology, Part I: Europe. Developments in Quaternary Science 2, 135-146. https://doi. org/10.1016/S1571-0866(04)80064-2

Fredningsstyrelsen 1977: Kortlægning af sømaterialer i Hjelm Bugt og Grønsund, 46 sider + appendiks. København: Miljøministeriet.

Fredningsstyrelsen 1986: Fakse Bugt. Råstoffer og fredningsinteresser, 38 sider + appendiks. København: Miljøministeriet.

GEUS 1997: Well data summary sheets, volume 32. Released wells from the Danish islands and Kattegat. Danmarks og Grønlands Geologiske Undersøgelse Rapport 1997/119, 118 sider.

Gravesen, P. \& Fredericia, J. (red.) 1984: ZEUS-geodatabase system, Borearkivet. Databeskrivelse, kodesystem og sideregistre. Danmarks Geologiske Undersøgelse Serie D 3, 259 sider. https://doi. org/10.34194/seried.v3.7120

Gravesen, P., Pedersen, S.A.S., Klint, K.E.S. \& Jakobsen, P.R. 2006: Geologiske kort i Danmark - hvad viser de kvartærgeologiske kort. Geologisk Nyt 2/2006, 10-14. https://doi.org/10.7146/gn.v0i2.3552

Gravesen, P., Binderup, M., Houmark-Nielsen, M. \& Krüger, J. 2017: Geologisk set - Sjælland og øerne, 333 sider. København: GEUS, Københavns Universitet, Geocenter Danmark og Geo-Forlag.

Gripp, K. 1948: Jasmund und Möen, eine glazialmorphologische Untersuchung. Zeitschrift für Erdkunde 1, 175-182. https://doi.org/10.3112/ erdkunde.1947.02.04

Hansen, S. 1965: The Quaternary of Denmark. I: Rankama, K. (red.): The Geologic Systems, the Quaternary 1. New York-London-Sydney: Interscience Publishers, 1-90.

Hansen, S. \& Nielsen, A.V. 1960: Glacial Geology of Southern Denmark. Guide to Excursions Nos A 44 and C 39. International Geological Congress, Norden 1960, 56 sider + kortbilag.

Heiberg, E.O. 1991: Senglaciale søer. Varv 4, 104-118.

Heiberg, E.O. \& Bennike, O. 1997: Late Quaternary rodents from the southwestern Baltic Sea. Baltica 10, 47-52.

Hintze, V. 1904: Trues Møens Klint med Ødelæggelse fra Havet? Meddelelser fra Dansk Geologisk Forening 2, 41-54.

Hintze, V. 1920: Skredene ved Liselund paa Møen. Meddelelser fra Dansk Geologisk Forening 5, 54

Hintze, V. 1926: Kvartære Niveauændringer i Forbindelse med Dan nelsen af Møens Klint. Foredragsreferat fra møde d. 4. marts 1926, Geologiska Föreningen Förhandlingar 48, H2, 287-292. Stockholm.

Hintze, V. 1937: Møens Klints geologi (Mertz, E.L. og Nordmann, V. red. posthumt) København: Reitzels Forlag, 410 sider.

Houmark-Nielsen, M. 1987: Pleistocene stratigraphy and glacial history of the central part of Denmark. Bulletin of the Geological Society of Denmark 36, 1-189. https://doi.org/10.37570/bgsd-1988-36-01

Houmark-Nielsen, M. 1988: Nyt om sidste istid. Klintholm, et nyt kvartærgeologisk nøgleprofil. Varv 4, 126-138.

Houmark-Nielsen, M. 1994: Late Pleistocene stratigraphy, glaciation chronology and Middle Weichselian environmental history from Klintholm, Møn, Denmark. Bulletin of the Geological Society of Denmark 41, 181-202. https://doi.org/10.37570/bgsd-1995-41-16

Houmark-Nielsen, M. 1999: A lithostratigraphy of Weichselian glacial and interstadial deposits in Denmark. Bulletin of the Geological Society of Denmark 46, 101-114. https://doi.org/10.37570/bgsd-1999-46-09

Houmark-Nielsen, M. 2003: Geologiske mærkværdigheder: Kritik af en model for det danske istidslandskabs dannelse. Geologisk Tidsskrift 1, 11-20.

Houmark-Nielsen, M. 2007: Extent and age of Middle and Late Pleistocene glaciations and periglacial episodes in southern Jylland, Denmark. Bulletin of the Geological Society of Denmark 55, 9-35. https:// doi.org/10.37570/bgsd-2007-55-02

Houmark-Nielsen, M. 2008: Testing OSL failures against a regional Weichselian glaciation chronology from southern Scandinavia. Boreas 37, 660-677. https://doi.org/10.1111/j.1502-3885.2008.00053.x

Houmark-Nielsen, M. 2010: Extent, age and dynamics of Marine Isotope Stage 3 glaciation in the southwestern Baltic Basin. Boreas 39, 343359. https://doi.org/10.1111/j.1502-3885.2009.00136.x
Houmark-Nielsen, M. \& Kjær, K.H. 2003: Southwest Scandinavia, 40-15 kyr BP: palaeogeography and environment change. Journal of Quaternary Science 18, 769-786. https://doi.org/10.1002/jqs.802

Houmark-Nielsen, M., Bennike, O., Lamdahl, G. \& Lüthgens, C. 2016: Evidence of ameliorated Middle Weichselian climate and sub-arctic environment in the western Baltic region: coring lake sediments at Klintholm, Møn, Denmark. Boreas 45, 347- 359. https://doi. org/10.1111/bor.12159

Houmark-Nielsen, M., Knudsen, K.L. \& Noe-Nygaard, N. 2017: Istider og mellemistider. I: Larsen, G. (red.): Geologien, 3. udgave, 255-303. København: Gyldendal.

Hyde, G. 1986: En glacialgeologisk og glacialmorfologisk undersøgelse af klinterne på Nordøstmøn samt klinternes bagland. Upubliceret cand. scient.-afhandling, Geologisk Institut, Københavns Universitet, 115 sider.Haarsted, V. 1956: De kvartærgeologiske forhold på Møn. Meddelelser fra Dansk Geologisk Forening 13, 124-126.

Håkansson, E. \& Pedersen, S.A.S. 1992: Geologiske kort over den danske undergrund 1:500 000. København: Varv, særudgivelse.

Jakobsen, P.R., Hermansen, B.V. \& Tougaard, L. 2015: Danmarks digitale jordartskort 1:25 000. Danmarks og Grønlands Geologiske Undersøgelse Rapport 2015/30, 29 sider.

Jelby, M.E., Thibault, N., Surlyk, F., Ullmann, C.V., Harlou, R. \& Korte, C. 2014: The lower Maastrictian Hvidskud succession, Møns Klint, Denmark: calcareous nannofossil biostratigraphy, carbon isotope stratigraphy, and bulk and brachiopod oxygen isostopes. Bulletin of the Geological Society of Denmark 62, 89-104. https://doi.org/10.37570/ bgsd-2014-62-05

Jensen, J.B. 1993: Late Weichselian deglaciation pattern in the southwestern Baltic: Evidence from the glacial deposits off the island of Møn, Denmark. Bulletin of the Geological Society of Denmark $\mathbf{4 0}$ 314-331. https://doi.org/10.37570/bgsd-1993-40-15

Jensen, J.B., Bennike, O., Witkowski, A., Lemke, W. \& Kuijpers, A. 1997: The Baltic Ice Lake in the southwestern Baltic: sequence-, chrono- and biostratigraphy. Boreas 26, 217-236. https://doi. org/10.1111/j.1502-3885.1997.tb00853.x

Jessen, K. 1929: Bjørnen (Ursus arctos L.) i Danmark. Danmarks Geologiske Undersøgelse IV Række 2(6), 16 sider. https://doi.org/10.34194/ raekke4.v2.6972

Johansen, A.C. 1904: Om den Fossile Kvartære Molluskfauna i Danmark og dens Relationer til Forandringer i Klimaet. Land- og Ferskvandsmolluskfaunaen, 137 sider + bilag. København: Nordisk Forlag.

Johnstrup, F. 1874: Ueber die Lagerungsverhältnisse und die Hebungsphänomene in den Kreidefelsen auf Möen und Rügen. Zeitschrift der deutschen geologischen Gesellschaft, 533-585.

Klint, K.E.S., Rasmussen, L. Aa, \& Jakobsen, P.R. 2017: Geologisk kort over Danmark 1:50 000, Stubbekøbing. København: De Nationale Geologiske Undersøgelser for Danmark og Grønland.

Knudsen, K.L. 1991: Marine Eemian and Early Weichselian deposits in northern Denmark - a review of the foraminiferal stratigraphy. Quaternary International 10-12, 167-171. https://doi. org/10.1016/1040-6182(91)90049- $t$

Knudsen, K.L., Jiang, H., Gibbard, P.L., Kristensen, P., Seidenkrantz, M.-S., Janczyk-Kopikowa, Z. \& Marks, L. 2011: Environmental reconstructions of Eemian Stage interglacial marine records in the Lower Vistula area, southern Baltic Sea. Boreas 41, 209-234. https://doi. org/10.1111/j.1502-3885.2011.00232.x

Kolstrup, E. 1982: Late Glacial pollen diagrams from Hjelm and Draved Mose (Denmark) with a suggestion of the possibility of drought during the Earlier Dryas. Review of Paleobotany and Palynology 36, 35-63. https://doi.org/10.1016/0034-6667(82)90013-6

Kolstrup, E. \& Houmark-Nielsen, M. 1991: Weichselian palaeoenvironments at Kobbelgård, Møn, Denmark. Boreas 20(2), 169-182. https:// doi.org/10.1111/j.1502-3885.1991.tb00305.x

Konradi, P.B. 1973: Foraminiferas in some Danish glacial deposits. Bulletin of the Geological Institutions of the University of Uppsala 5, 173-175.

Konradi, P.B. 1976: Foraminifera in Eemian deposits at Stensigmose, southern Jutland. Danmarks Geologiske Undersøgelse II Række 105, 54 sider + bilag. https://doi.org/10.34194/raekke2.v105.6896 
Kristensen, P., Gibbard, P., Knudsen, K.L. \& Ehlers, J. 2000: Last Interglacial stratigraphy at Ristinge Klint, South Denmark. Boreas 29, 103-116. https://doi.org/10.1111/j.1502-3885.2000.tb01204.x

Krog, H. 1979: The Quaternary History of the Baltic Denmark. I: Gudelis, V. \& Königsson, L.-K. (red.): The Quaternary History of the Baltic. Symposia Universitatis Upsaliensis annum quingentesimum celebrantis 1, 207-217.

Krüger, J. \& Kjær, K.H. 1999: A data chart for field description and genetic interpretation of glacial diamicts and associated sediments - with examples from Greenland, Iceland, and Denmark. Boreas 28, 386402. https://doi.org/10.1111/j.1502-3885.1999.tb00228.x

Madsen, V. 1916: Ristinge Klint. Danmarks Geologiske Undersøgelse IV Række 1(2), 32 sider.

Madsen, H.B. \& Stemmerik, L. 2010: Diagenesis of flint and porcellanite in the Maastrichtian Chalk at Stevns Klint, Denmark. Journal of Sedimentary Research 80, 578-588. https://doi.org/10.2110/jsr.2010.052

Madsen, V., Nordmann, V. \& Hartz, N. 1908: Eem-Zonerne. Studier over Cyprinaleret og andre Eem-Aflejringer i Danmark, Nord-Tyskland og Holland. Danmarks Geologiske Undersøgelse II Række 17, 302 sider. https://doi.org/10.34194/raekke2.v17.6800

Mikkelsen, V.M. 1949: Præstø Fjord. The development of the postglacial vegetation and a contribution to the history of the Baltic Sea. Dansk Botanisk Arkiv 13, 171 sider + appendiks.

Miller, G.H. \& Mangerud, J. 1985: Aminostratigraphy of European marine interglacial deposits. Quaternary Science Reviews 4, 21-278. https:// doi.org/10.1016/0277-3791(85)90002-2

Milthers, V. 1948: Det danske Istidslandskabs Terrænformer og deres Opstaaen. Danmarks Geologiske Undersøgelse III Række 28, 234 sider. https://doi.org/10.34194/raekke3.v28.6933

Nadim, F., Pedersen, S.A.S., Schmidt-Thomé, P., Sigmundsson, F. \& Engdahl, M. 2008: Natural hazards in Nordic Countries. Episodes 31, 176184. https://doi.org/10.6027/9789289350846-4-en

Nielsen, L.H. \& Japsen, P. 1991: Deep wells in Denmark 1935-1990. Lithostratigrahic subdivision. Danmarks Geologiske Undersøgelse Serie A 31, 175 sider. https://doi.org/10.34194/seriea.v31.7051

Noe-Nygaard N. \& Heiberg, E.O. 2001: Lake-level changes in the Late Weichselian Lake Tøvelde, Møn, Denmark: induced by changes in climate and base level. Palaeogeography, Palaeoclimatology, Palaeoecology 174, 351-382. https://doi.org/10.1016/s0031-0182(01)00315-7

Noe-Nygaard, N., Knudsen, K.L. \& Houmark-Nielsen, M. 2017: Fra Istid til og med Jægerstenalder. I: Larsen, G. (red.): Geologien, 3. udgave, 305-334. København: Gyldendal.

Pedersen, S.A.S. 1988: Glacitectonite: Brecciated sediments and cataclastic sedimentary rocks formed subglacially. I: Goldthwait \& Matsch (red.): Genetic Classification of Glacigene Deposits, 89-91. Rotterdam: Balkema.

Pedersen, S.A.S. (red.) 1989: Jordartskort over Danmark, 1:200 000, Sjælland, Øer og Bornholm, kort 4. København: Danmarks Geologiske Undersøgelse.

Pedersen, S.A.S. 1994: Skred på Møns Klint. Geologisk Nyt 3/1994, 3-5.

Pedersen, S.A.S. 2000: Superimposed deformation in glaciotectonics. Bulletin of the Geological Society of Denmark 46, 125-144. https://doi. org/10.37570/bgsd-1999-46-11

Pedersen, S.A.S. 2003: Vurdering af skredrisiko for området oven for Maglevandsfaldet på Møns Klint. Strukturel undersøgelse af de glacialtektoniske forhold i klintområdet ved Hotel Storeklint, Møns Klint, Møn. Danmarks og Grønlands Geologiske Undersøgelse Rapport 2003/50, 31 sider + appendix.

Pedersen, S.A.S. 2005: Structural analysis of the Rubjerg Knude Glaciotectonic Complex, Vendsyssel, northern Denmark. Geological Survey of Denmark and Greenland Bulletin 8, 192 sider + 2 plates. https://doi. org/10.34194/geusb.v8.5253

Pedersen, S.A.S. 2006: Strukturer og dynamisk udvikling af Rubjerg Knude Glacialtektoniske Kompleks, Vendsyssel, Danmark. Geologisk Tidsskrift, hæfte 1, 46 sider.

Pedersen, S.A.S. 2007: Skred ved Møns Klint, Store Taler forsvundet. Naturens Verden 4/2007, 21-23.

Pedersen, S.A.S. 2011: Isfoldede lag i de danske kystklinter. I: Lindow, B. \& Krüger, J. (red.): Geologiske naturperler - danske brikker til Jordens puslespil, 113-127. København: Gyldendal.
Pedersen, S.A.S. 2012a: Glaciodynamic sequence stratigraphy. I: Huuse, M. et al. (red.): Glaciogenic Reservoirs and Hydrocarbon Systems. London: Geological Society, Special Publications 368, 29-51. https://doi. org/10.1144/sp368.2

Pedersen, S.A.S. 2012b: Rockfalls at chalk cliffs in northern Europe. I: Eberhardt, E. et al. (red.): Landslides and Engineered Slopes 2: Protecting Society through Improved Understanding, 1127-1132. London: Taylor \& Francis Group.

Pedersen, S.A.S. 2014: Architecture of Glaciotectonic Complexes. Geosciences 4, 28 sider. https://doi.org/10.3390/geosciences4040269

Pedersen, S.A.S., Foged, N. \& Frederiksen, J. 1989: Extent and economic significance of landslides in Denmark, Faroe Islands and Greenland. I: Brabb, E.E. \& Harrod, B.L. (red.): Landslides, Extent and Economic Significance, 15-156. Rotterdam: Balkema.

Pedersen S.A.S. \& Gravesen, P. 2005: Geologisk kortlægning af det østlige Møn. Pilotprojekt Nationalpark Møn, 15 sider + kortbilag. Danmarks og Grønlands Geologiske Undersøgelse.

Pedersen, S.A.S. \& Gravesen, P. 2009: Structural development of Maglevandsfald: a key to understanding the glaciotectonic architecture of Møns Klint, SE Denmark. Geological Survey of Denmark and Greenland Bulletin 17, 29-32. https://doi.org/10.34194/geusb.v17.5007

Pedersen, S.A.S. \& Petersen, K.S. 1997: Djurslands Geologi, 96 sider. København: Danmarks og Grønlands Geologiske Undersøgelse.

Pedersen, S.A.S., Fredericia, J. \& Rasmussen, L.Aa. 2015: Kortbladsbeskrivelse til Geologisk kort over Danmark, 1:50 000, Sakskøbing 1411 I og 1412 II Syd. Geological Survey of Denmark and Greenland Map Series 6, 42 sider + kort. https://doi.org/10.34194/geusm.v6.4564

Pedersen, S.A.S., Gravesen, P. \& Hinsby, K. 2018: Chalk-glaciotectonite, an important lithology in former glaciated terrains covering chalk and limestone bedrock. Geological Survey of Denmark and Greenland Bulletin 41, 21-24. https://doi.org/10.34194/geusb.v41.4333

Petersen, K.S. 1984. Stratigraphical position of Weichselian tills in Denmark. Striae 20, 75-78.

Pontoppidan, E. 1768: Det Danske Atlas, 851 sider. Kjøbenhavn: Tomus IV.

Puggaard, C. 1851: Møens Geologie. Universitetets Guldmedaille Priisskrift, 287 sider. København: Reitzel.

Puggaard, C. 1852: Geologie der Insel Möen, 29-71. Leipzig: Weigel.

Rambøll 2006: Møn - Fase 1 kortlægning. Hovedrapport, 90 sider +47 bilag. Udarbejdet for Storstrøms Amt.

Rambø|l 2007: Møn - Fase 2 kortlægning. Hovedrapport, 90 sider + 36 bilag. Udarbejdet for Storstrøms Amt.

Rasmussen, H.W. 1965: Møn. Landskab og undergrund. Faglig Læsning 36. årgang 64, 32 sider.

Region Sjælland 2012: Råstofplan for Region Sjælland 2012-2023. Bøgebjerg Graveområde, 97-99.

Rosentau, A., Bennike, O., Uscinowicz, S. \& Miotk-Szpiganowicz, G. 2017: The Baltic Sea Basin. I: Flemming, N.C. et al. (red.): Submerged Landscapes of the European Continental Shelf: Quaternary Paleoenvironments, 103-133. https://doi.org/10.1002/9781118927823.ch5

Schou, A. 1949: Atlas over Danmark I. Landskabsformerne. Det Kongelige Danske Geografiske Selskab.

Seidenkrantz, M.-S., Knudsen, K.L. \& Kristensen, P. 2000: Marine late Saalian to Eemian environments and climatic variability in the Danish shelf area. Geologie en Mijnbouw/ Netherlands Journal of Geosciences 79, 335-343. https://doi.org/10.1017/s0016774600023696

Selsing, L. 1982: Radiocarbon dating of a mammoth tusk fragment from Brorfelde, Denmark. Bulletin of the Geological Society of Denmark 31, 151-157.

Sjørring, S., Nielsen, P.E., Frederiksen, J., Hegner, J., Hyde, G., Jensen, J.B., Mogensen, A., \& Vortisch, W. 1982: Observationer fra Ristinge Klint, felt- og laboratorieundersøgelser. Dansk Geologisk Forening Årsskrift for 1981, 135-149.

Slater, G. 1927: The Structure of the Disturbed Deposits of Møens Klint, Denmark. Transactions of the Royal Society, Edinburgh 55, 289-302. https://doi.org/10.1017/s0080456800016355

Smed, P. 2010: Indicator count methods tested out on Møn, Denmark. E\&G Quaternary Science Journal 59, 76-87. https://doi.org/10.3285/ eg.59.1-2.07

Smed, P. 2014: Weichsel istiden på Sjælland. Geologisk tidsskrift 2013, $1-42$. 
Smed, P. \& Ehlers, J. 2002: Steine aus dem Norden, 194 sider. Berlin, Stuttgart: Gebrüder Borntraeger.

Sorgenfrei, T. 1966: Strukturgeologischer Bau von Dänemark. Geologie 15, 641-660.

Sorgenfrei, T. \& Buch, A. 1964: Deep Tests i Denmark 1935-1959. Danmarks Geologiske Undersøgelse II Række 36, 146 sider. https://doi. org/10.34194/raekke3.v36.6941

Stockmarr, T.K. 1996: En kvartærgeologisk model over det sydvestlige Møn. Upubliceret cand.scient.-afhandling, Geologisk Institut, Københavns Universitet, 164 sider +6 bilag og 10 appendikser.

Storstrøms Amt 2004: Tillæg nr. 8 til Regionplan 2001-2013. Råstofplanlægning. Møn Kommune, Busemarke/NyBorre, 50-53.

Surlyk, F. 1971: Skrivekridtklinterne på Møn. I: Hansen, M. \& Poulsen, V. (red.): Geologi på Øerne. København: Varv (særudgivelse), 5-24.

Surlyk, F. 1984: The Maastrichtian Stage in NW Europe and its brachiopod zonation. Bulletin of the Geological Society of Denmark 33, 217-223.

Surlyk, F. 2017: Fra ørkener til varme have. I: Larsen, G. (red.): Naturen i Danmark. Geologien, 3. udgave, 139-180. København: Gyldendal.

Surlyk, F. \& Håkansson, E. 1999: Maastrichtian and Danian strata in the southeastern part of the Danish Basin. I: Pedersen, G.K. \& Clemmensen, L.B. (red.): Field Trip Guidebook. International Association of Sedimentologists, 19th Regional European Meeting of Sedimentology, 24-26 August 1999, 29-58.

Surlyk, F., Damholt, T. \& Bjerager, M. 2006: Stevns Klint Denmark: Uppermost Maastrichtian chalk, Cretaceous-Tertiary boundary, and lower Danian bryozoan mound complex. Bulletin of the Geological Society of Denmark 54, 1-46 + bilag. https://doi.org/10.37570/bgsd-2006-54-01

Surlyk, F., Rasmussen, S.L., Boussaha, M., Schiøler, P., Schovsbo, N.H. Sheldon, E., Stemmerik, L. \& Thibault, N. 2013: Upper CampanianMaastrichtian holostratigraphy of the eastern Danish Basin. Cretaceous Research 46, 232-256. https://doi.org/10.1016/j.cretres.2013.08.006

Thomsen, E. 1995: Kalk og kridt i den danske undergrund. I: Nielsen, O.B. (red.): Danmarks geologi fra kridt til i dag, 31-67. Aarhus: Geologisk Institut, Aarhus Universitet

Ukkonen, P., Arppe, L., Houmark-Nielsen, M., Kjær, K.H. \& Karhu, J.A. 2007: MIS 3 mammoth remains from Sweden - implications for faunal history, palaeoclimate and glaciation chronology. Quaternary Science Reviews 26, 3081-3098. https://doi.org/10.1016/j.quascirev.2007.06.021

Ødum, H. 1933: Marint Interglacial paa Sjælland, Hven, Møn og Rügen. Danmarks Geologiske Undersøgelse IV Række 2(10), 44 sider. https:// doi.org/10.34194/raekke4.v2.6980 